\title{
Eukasz Wróblewski
}

\section{Culture Management \\ Strategy and Marketing Aspects}

Foreword by Bonita M. Kolb

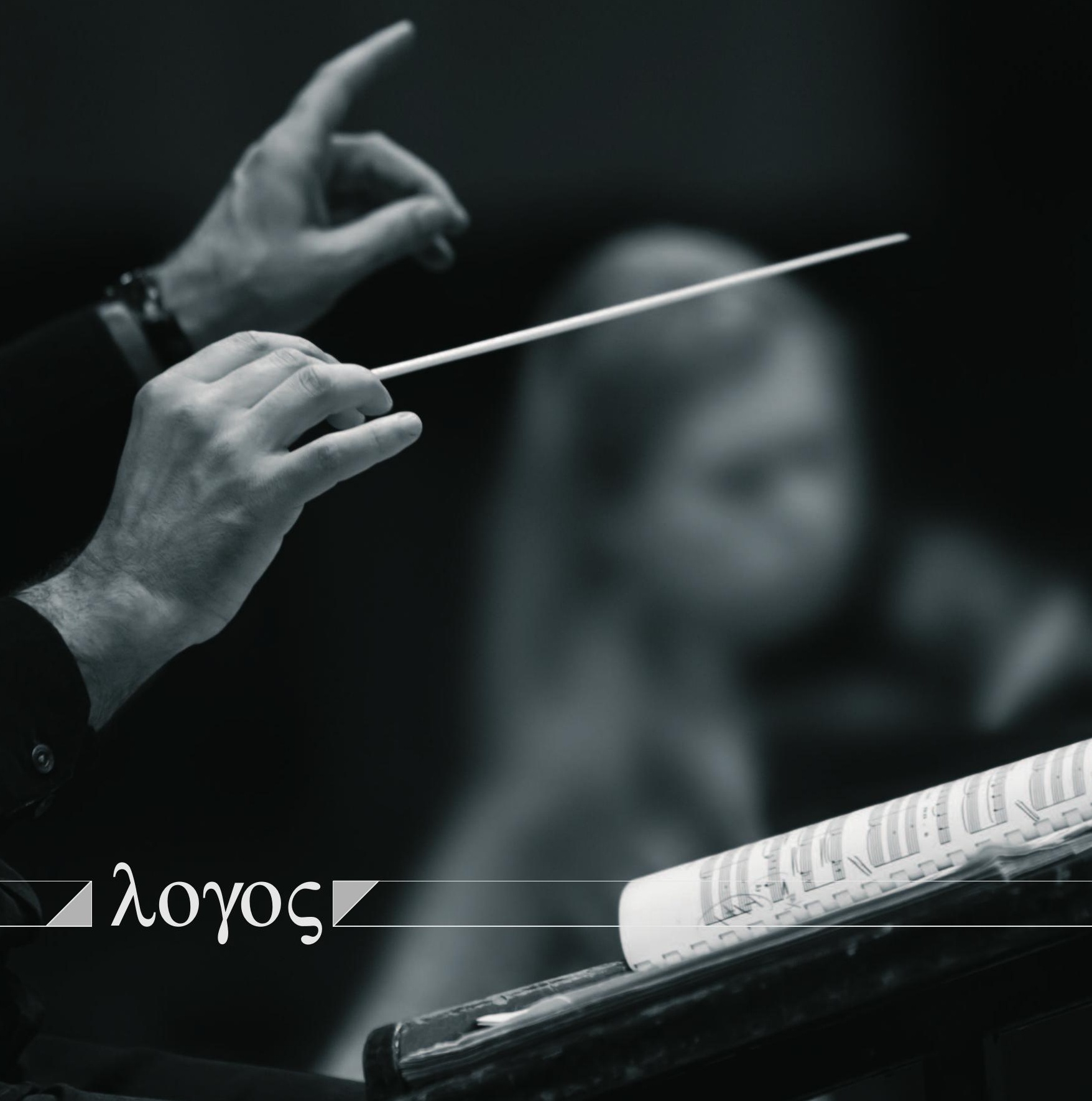





\section{Culture Management Strategy and marketing aspects}





\section{Łukasz Wróblewski}

\section{Culture Management Strategy and marketing aspects}

Foreword by Bonita M. Colb

$$
\text { SS }
$$

Logos Verlag Berlin

2017 
Reviewer:

Bonita M. Kolb, Ph.D.

Professor Emeritus of Business Administration

Lycoming College in Pennsylvania, USA

www.bonitakolb.com

Bibliographic information published by the Deutsche Nationalbibliothek

The Deutsche Nationalbibliothek lists this publication in the Deutsche National-bibliografie; detailed bibliographic data are available in the Internet at http://dnb.d-nb.de.

The electronic version of this book is freely available under CC BY-SA 4.0 licence, thanks to the support of libraries working with Knowledge Unlatched (KU). KU is a collaborative initiative designed to make high quality books Open Access for the public good. More information about the initiative and links to the Open Access version can be found at www.knowledgeunlatched.org.

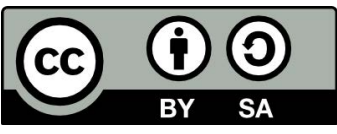

C Copyright Logos Verlag Berlin 2017

All rights reserved.

ISBN 978-3-8325-4378-5

Cover photo:

Hands of conductor in black and white \#100922050 - Fotolia.com

Logos Verlag Berlin

Comeniushof, Gubener Str. 47,

10243 Berlin; Germany

Tel.: +4903042851090

Fax: +4903042851092 


\section{Contents}



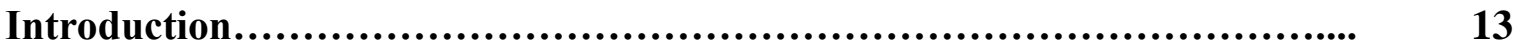

1 The meaning and essence of the cultural sector......................... 17

$1 \quad$ Culture and its divisions.......................................... 17

2 Relationships between culture, cultural industries, and creative industries.................................................... 22

3 Typology of cultural institutions............................. 35

$4 \quad$ Culture and its industries as factors stimulating socio-economic development................................................. 37

References.......................................................... 42

2 Conditions for the development of marketing in organizations in the cultural sector..........................................................

1 Conditions for the application of marketing in culture and cultural industries.......................................... 45

2 The concept and objectives of marketing in culture.................. 50

3 Typical objections to marketing in culture......................... 54

4 Model of the marketing concept in the cultural sector................. 56

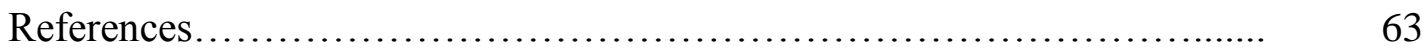

3 Strategic and marketing planning in cultural institutions................ $\quad 65$

1 The role and importance of mission in cultural institutions............ 65

2 Strategic objectives and the main directions of development of cultural entities............................................... 71 
3 Market segmentation in the cultural sector.

3.1 Criteria for segmentation.................................. 84

3.2 Most important categories of customers in the cultural sector... 86

3.3 Types of marketing approaches............................ 89

4 Choosing a course of action and marketing instruments............... 90

5 Models of marketing strategies of cultural institutions in relation to specified target markets..................................... 98

5.1 Characteristics of the analyzed target markets of cultural institutions

5.2 Elitist art strategy

5.3 Art emphasizing strategy.............................. 102

5.4 Strategy of increasing sensitivity to art.................... 103

5.5 Art popularizing strategy.............................. 104

6 Problems with the implementation of marketing strategy in entities of the cultural sector.

\section{Marketing strategies based on relationships with key market} participants.......................................................... 111

1 The process of forming relationships.......................... 111

2 Shaping relationships with consumers of the cultural offer............ 115

3 Developing relationships with donors............................ 119

4 Developing relationships with employees....................... 133

References..................................................... 138

\section{$5 \quad$ New media and technology in strategic activities of cultural} organizations............................................................. 141

1 Websites in the marketing activities of cultural organizations.......... 141

2 Social media as a tool for marketing communication among entities of the cultural sector. 
2.1 The goals and importance of using social media

in the marketing communication of cultural entities

2.2 Segmentation of social media users in relation

to cultural institutions

2.3 Fan pages in the marketing activities of cultural institutions.....

2.4 The possibilities of using YouTube in the promotion

of entities in the cultural sector.

2.5 Blogs as a specific tool for the communication

of cultural institutions with the market

3 Possibilities of using holograms and virtual advisors

in the cultural sector.

4 Virtual tours as a modern form of presentation

of cultural institutions

5 Mobile applications in the cultural sector - case studies

5.1 "DailyArt" mobile application

5.2 "Wilanów Live" mobile application

5.3 "My Warsaw" mobile application.

5.4 Mobile application of the Łódź City Museum.

5.5 "Archimapa" and "Via Ducalis" mobile planners

Summary

Tables and Figures. 



\section{Foreword}

I was pleased when Dr Wróblewski asked me to write a foreword for Culture Management: Strategy and Marketing Aspects. The field of cultural management and marketing has changed dramatically since the first edition of my book Marketing for Cultural Organizations was published in 2000. Dr Wróblewski carries forward the work of understanding the use of business strategy in cultural organizations. At the time my book was published, the idea of using business models to guide the strategy of cultural organizations was strongly resisted. Now many managers and marketers who work for nonprofit cultural organizations understand that they need to develop and implement a business strategy if they are going to survive.

Dr Wróblewski's book explains clearly what has changed to make the use of business models necessary, even in organizations which might have resisted in the past. Globalization has resulted in a population which understands and appreciates art and culture created in other countries. While it might be agreed that this is beneficial for society, it means that cultural arbitrators within a country no longer have the authority to dictate what is accepted as culture. Managers now understand that to gain the support of the public they must explain the benefits of consuming their cultural product.

Besides a sharing of culture across borders resulting in a reduction of cultural hierarchy, Dr Wróblewski explains how the growth of available entertainment options has affected cultural organizations. Previous generations' distinction between high art and popular culture is simply not relevant in a democratized world where people feel free to enjoy whatever entertainment they wish. Both because it is what audiences demand and due to the need for revenue, cultural institutions are faced with the pressure to define their product more broadly. Finally, technology has affected every aspect of life, and the public expects cultural organizations to keep pace. Globalization, technology, and competition from other cultural 
and entertainment options have resulted in a need for organizations to ensure that their strategies meet the changing needs of the consumer.

I believe that the typology of the cultural industries described in Chapter One is particularly helpful for the reader. Previously it was easy to describe cultural institutions as product-focused and cultural industries as market-focused. After reading Dr Wróblewski's book I believe there will be an inevitable blurring of this distinction. In fact, while cultural institutions focus more on the market, cultural industries may begin to produce more original artistic work. In the future, cultural managers must be able to balance both types of focus at the same time.

In Chapter Two, which discusses the application of marketing to cultural organizations, I would point the reader's attention to Figure 2.2. Here, I believe, Dr Wróblewski addresses an important emerging issue for cultural institutions. Traditionally these organizations were the arbitrators who deemed what culture was 'worthy'. With the democratization of culture and use of technology to disseminate cultural products they are now being bypassed. Individuals who are producing the creative product can now, thanks to technology, go directly to the public with what they produce.

The basis of Chapter Three is a study of the missions and objectives of Polish opera houses. However, it would be an error for the reader to believe that the analysis is only applicable to this type of institution. Reading the chapter should help any manager understand the relationship between their mission and their strategy. Cultural institutions face unique challenges in developing a marketing strategy: these organizations were usually started by a founder with a vision, not started to meet an existing consumer need. In addition, the product is unique and often does not easily communicate its value. What I found of interest is Dr Wróblewski's argument that there is no focus on a competitive advantage. Cultural institutions, such as opera houses, believe in cooperation rather than competition. A competitive advantage is determined by consumer wants and needs and the basis of marketing strategy. When these wants and needs are not part of the original founding of the organization, developing a marketing strategy will be difficult. 
Dr Wróblewski finds that most missions are product-focused only in that they describe the cultural product they are presenting. A thorough analysis of the institutions' objectives finds that most focus on artistic quality and dissemination of the work, with little or no emphasis on socio, cultural, market, or financial objectives. While in the past an emphasis on only the artistic product was acceptable, it now leaves the cultural organization vulnerable.

According to Dr Wróblewski, one of the issues that keeps cultural institutions from taking a more market-centered approach to strategy is that they define their market segment very broadly. If marketing strategy is based on the consumer, it is understandable that the more widely the institutions define their market segment, the more difficult it is to develop a strategy. His suggestion is that the institutions develop separate strategies for customers, donors, and employees.

If the reader is looking for inspiration on how to communicate the value of their cultural institution's product to the consumer, Chapter Five provides many examples, exploring how technology now helps bridge the divide between the institution and the public. Marketing isn't simply focused on promotion; marketing is also focused on making it easy for the consumer and organization to interact. If this is done effectively, interest in the product will develop.

There is still some resistance from the managers of cultural institutions to implementing business strategy. They can learn from this book that marketing models can be used while still adhering to a mission. It is the responsibility of the manager to ensure a correct balance between the artistic mission and attracting the public.

Bonita M. Kolb

Professor Emeritus of Business Administration

Lycoming College in Pennsylvania, USA

Nashville, $27^{\text {th }}$ November 2016 



\section{Introduction}

Any business entity which wishes to maintain and strengthen its position in the market must adapt to changing market conditions and the requirements and needs of its customers. This applies to all sectors of the economy, including business entities in the cultural sector, such as cultural institutions. For over twenty years, we have been able to observe dynamic developments in this sector, which have thus brought about a change in its business structure. This change is mainly reflected in the increase in the number of private institutions and companies in culture-related industries, which in turn has led to ever more pronounced competition in the sector. As a result, managers have been forced to become interested in strategic and marketing management. It has turned out, however, that a lack of basic theoretical knowledge and practical experience has seriously encumbered the efficient preparation and implementation of activities in this area. Difficulties with the use of strategic management and marketing strategies in the cultural sector have been mainly due to a lack of knowledge and sometimes even an aversion to marketing of managers of cultural institutions, as well as its erroneous identification with sales and advertising. Therefore, the main objective of this paper is to present some strategic solutions and to model marketing strategies and other activities in the area of marketing that can be applied in the cultural sector. The practical application aspect of the paper is evident in the indication of the direction future marketing efforts of cultural institutions should take in order to improve their market position. The following issues have been subjected to a detailed analysis:

- Missions and strategic objectives of cultural institutions;

- Difficulties associated with formulating the mission and strategic objectives of cultural sector entities;

- Customer segmentation criteria used by cultural institutions;

- Choosing a course of action and marketing tools; 
- The greatest problems associated with the implementation of marketing strategy in the cultural sector;

- New media in the marketing activities of cultural institutions;

- The possibility of using modern technologies in the marketing communications of cultural entities.

The study consists of five chapters. The arrangement of the book's content - leading the reader from general topics to specific issues, as well as the presentation of the content through numerous drawings, graphs and charts - give the book a very practical dimension.

The first chapter, "The Meaning and Essence of the Cultural Sector", is a theoretical introduction to the issue of management in culture. It introduces and organizes the basic conceptual apparatus related to culture, cultural industries, creative industries, and the cultural sector. The study also presents the division of cultural entities in regard to their marketing orientation and discusses the impact of the cultural sector on socio-economic development.

The second chapter, "Conditions for the Development of Marketing in Organizations in the Cultural Sector", analyses the conditions for the application of marketing in the cultural sector, the concepts and objectives of marketing culture, as well as the most common reservations or objections it faces. At the end of the chapter, the functional mechanism of the culture market (market conditions for the development of the concept of marketing in the cultural sector) is discussed, and two marketing models are analyzed. The first one has been adapted to the needs of the activities of cultural institutions, and the other can be used by companies in the cultural industries.

In the third chapter, "Strategic and Marketing Planning in Cultural Institutions", the key elements of marketing strategy are discussed on the basis of source literature and the results of research conducted in cultural institutions: mission and strategic objectives with the main problems in their formulation, the selection of a target market (segmentation criteria for customers of cultural institutions), as well as the selection of the marketing method and instruments (product, price, distribution, promotion, and staff). At the end, four model marketing strategies are proposed which can be used by managers of cultural institutions in 
relation to specified target markets. The main problems associated with the implementation and execution of marketing strategies adopted by cultural institutions are also discussed.

The fourth chapter, "Marketing Strategies Based on Relationships with Key Market Participants", shows the importance of issues related to the evolution of mutual relations between market participants in relation to the analyzed cultural sector. The chapter presents the process of developing long-term relationships between cultural institutions and stakeholders, as well as the most important measures (benchmarks) for the sustainability of the relationship. Original marketing strategies developed by drawing on original research, based on relationships between consumers of artistic offerings, donors, and employees, are presented.

The final, fifth chapter, "New Media and Technology in the Strategic Activities of Cultural Organizations", suggests directions which cultural institutions should take with regard to their future marketing activities. It presents new media and modern technologies as material for an effective marketing strategy. The chapter discusses the importance of social media (Facebook, Twitter, Instagram, YouTube, and blogs) in the marketing communications of cultural institutions. It also presents the possibilities of using holograms and virtual advisors as tools for the promotion of culture, as well as other innovative solutions such as virtual tours or applications for mobile devices (smartphones, laptops).

This book is primarily intended for students studying management and marketing in culture. I also believe that the structure of the paper and the issues raised within will be useful to cultural managers, employees in cultural institutions, organizers of cultural activities, impresarios, as well as independent artists who promote their work on their own. The paper may also be useful for businesses, for which cooperation with cultural institutions is a potential opportunity for the development of innovation, creativity, and the integration of employees. Cooperation between business and culture may in fact bring tangible benefits to all parties. 



\section{Chapter 1}

\section{The meaning and essence of the cultural sector}

\section{Culture and its divisions}

The source literature contains many different definitions of culture. This complex phenomenon is the subject of description and study by various disciplines: sociology, cultural anthropology, ethnography, cultural economics, and the emerging new discipline of culture management (including strategic and marketing management). Each of these disciplines studies and describes culture from its own perspective, leading to a lack of agreement regarding basic theoretical and methodological issues, which can even be seen in the different ways of understanding the main concepts used to describe socio-cultural reality, its phenomena, and its processes. Verbal and terminological disputes are not uncommon, in which the interpretation of the author's statements is inconsistent with their intentions. This is because when cultural researchers, workers, and managers who are directly involved in the promotion of culture use the same terms and descriptive phrases, they do not necessarily speak about the same objective reality, even when using the word "culture" (Grad and Kaczmarek 2005: 11).

Culture is one of the fundamental concepts of contemporary humanities, and although the use of the term only became widely popularized in the twentieth century, its etymological origin dates back to classical antiquity. The Latin word cultura originally meant simply the cultivation of soil, but Cicero, in the Tusculanae Disputationes, expanded its use to intellectual phenomena, calling philosophy the culture of spirit (Kłoskowska 1983: 9). Considering the etymology of this word, we could say that it describes everything that man does and that surrounds him, with the exception of the natural world. In the broadest 
meaning, culture is the entire material and spiritual heritage of humanity collected, preserved, and enriched over the course of its history, passed down from generation to generation (Polish language dictionary 1995: 1015). According to Szczepański (1965: 47), culture is the entirety of the material and non-material products of human activity, values, and practices recognized, objectified, and adopted within any collectivity, transferred to other collectivities and to future generations.

Tackling the issue of management and strategic marketing in the cultural sector, it is necessary to define the concept of culture, which delineates the scope of the characterized phenomena. When we compare the uses of the word "culture" as used by cultural managers, employees of cultural institutions, and cultural industries, and where culture is understood as a result of research in such disciplines as philosophy, sociology of culture, or cultural anthropology (ethnology), we note significant differences. In the first case, in official nomenclature, culture is simply used to refer to ways and means of disseminating culture, i.e. the form of disseminating culture (cultural activities). In this case we can speak about a practical and administrative understanding of culture. According to this approach, culture is "the whole of a specific type of projects: soirées, sightseeing tours possibly combined with visiting museums and architectural monuments, reader contests, folklore festivals, activities of various types of amateur groups: singing, dance, theater groups, etc." (Kmita 1982: 5-6). In this sense, culture becomes synonymous with "cultural life", that is, the collective participation in public forms of the dissemination of culture. In the second case, it is difficult to talk about a single notion. There are plenty of different theoretical and academic concepts of culture; with all their diversity, however, none of the theoretical and academic concepts of culture coincide with that block of events and group activities which are referred to as culture in practical and administrative terms.

Ethnological scientific literature devoted to culture has grown so much that an overview and the systematization of this concept has become a vital necessity. The most comprehensive overview of this kind thus far is presented in the 1952 paper by Kroeber and Kluckhohn. A critical overview of the concept of culture made by Kroeber and Kluckhohn takes into account six types of definitions of culture, or actually six different aspects which tend to be emphasized in various definitions, but rarely occur on their own or 
independently. These include the following aspects: descriptive, historical, normative, psychological, structural, and genetic (Kłoskowska 1983: 21).

The descriptive definition is the classic form of the early ethnological definitions. It is represented by, among others, the still-useful classic definition by Tylor: "Culture or civilization, taken in its wide ethnographic sense, is that complex whole which includes knowledge, belief, art, morals, law, customs, and any other capabilities and habits acquired by man as a member of society" (Kłoskowska 1983: 21). Historical definitions appearing in the second category mentioned by Kroeber and Kluckhohn emphasize the aspect of tradition constituting culture; for its definition, they use such expressions as inheritance and legacy. Normative definitions emphasize the subordination to standards as a property of cultural behavior; they focus on the unity of a "lifestyle" characterizing particular cultures. The definitions classified by the authors in the psychological category include the mechanisms of the mental development of culture, and thus the process of learning and forming habits. This category also includes definitions defining culture as an adaptive system. Structuralist definitions are characterized by their focus on the overall character of different cultures and their internal connections; definitions of this type speak about a specific culture or different cultures, not about culture in general. Genetic definitions place an emphasis on explaining the origin of culture, its juxtaposition to nature, and its character as a product of the social coexistence of humans.

The notion of culture is so internally varied that when describing marketing and strategic aspects of management, we cannot subject it to an overall analysis. It is necessary to isolate its specific areas. Culture can be divided into many areas, in an obvious way, as a set of forms of social consciousness. Each of them constitutes a specific form of social consciousness. As a result, we can distinguish between the following fields of culture (Kmita 1982: 73-74):

- Technical/functional culture, i.e. a form of social consciousness which regulates the primary practice (production, consumption, exchange);

- Language, i.e. a form of social consciousness which regulates the practice of language communication;

- Customs, i.e. a form of social consciousness which regulates customs; 
- Art, i.e. a form of social consciousness which regulates artistic practice;

- Science, i.e. a form of social consciousness which regulates the practice of research (science);

- Public political and legal awareness, i.e. a form of social consciousness which regulates political and legal practice;

- Public pedagogical awareness, i.e. a form of social consciousness which regulates institutional (school and non-school) teaching practice;

- Magic, i.e. a form of social consciousness, now basically a relic, in the past regulating the "material and magic" practice;

- Religion, i.e. a form of social consciousness which regulates religious practice;

- Public secular/worldview awareness, i.e. a form of social consciousness which regulates the secular/worldview-forming ("philosophical" in the broadest sense of the word) practice.

Therefore, the entire culture of a given society can be classified as follows: the first division of this culture is formed by the field that is defined as a technical/functional culture and which is a socio-subjective regulator of primary "material" practice (production, exchange, consumption), while the second division is made up of all the other fields of culture (language, customs, art, science; social, political, and legal awareness; social pedagogical awareness, magic, religion, social secular/worldview awareness). It is evident that these other fields of culture do not make up a single form of social consciousness; we can only speak of a certain sphere of social consciousness, a certain sphere of culture - a sphere of symbolic culture.

Kmita, in addition to the division of the cultural fields into technical/functional culture (civilization) and symbolic culture, also introduces a further breakdown into the culture of tangible values, and a worldview-forming sphere of symbolic culture. The first part of the second division covers not only technical/functional culture, but also some fields of symbolic culture. Hence, it can be applied to the division of symbolic culture itself. In this case, we obtain: symbolic culture of tangible values otherwise known as symbolic culture in the narrower sense, and the worldview-forming sphere of symbolic culture. The distinctions made between the spheres of culture are shown in Figure 1.1. 
Worldview-forming

Culture of tangible practical values sphere of symbolic culture

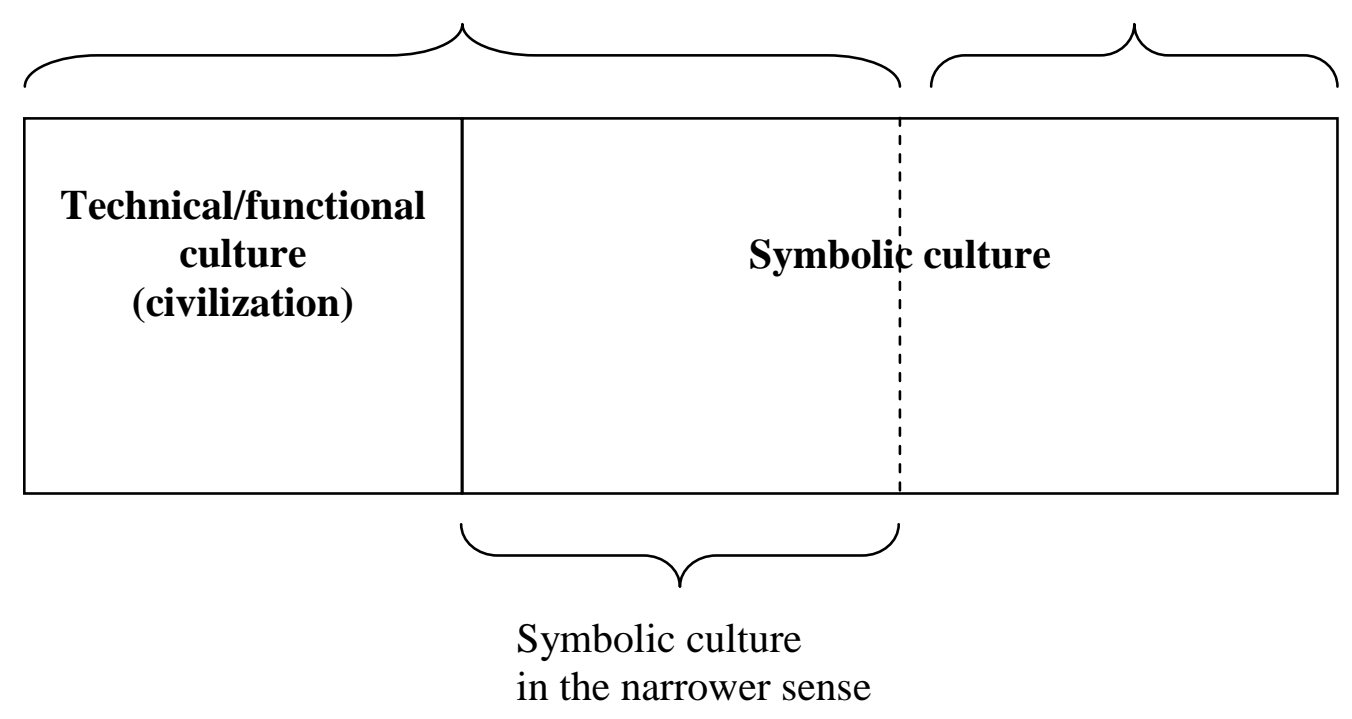

Figure 1.1 Division of culture. Source Kmita (1982: 85)

The fields of symbolic culture which have been accounted for have been divided as follows:

- Symbolic culture in the narrower sense (symbolic culture of tangible practical values): language, customs, art, science; social, political, and legal awareness;

- Worldview-forming sphere of symbolic culture: ("pure”) magic, religion, social secular/worldview-forming awareness.

Therefore, the culture of tangible practical values, covering normative beliefs, which determine tangible practical values, is divided into two different spheres: technical/functional culture, and symbolic culture in the narrower sense.

The immediate aim of this distinction of culture is to outline a certain concept of culture, and above all the area which we will use when describing the marketing and strategic aspects of management in culture and cultural industries. Therefore, for the purposes of this paper, the term "culture" is used in its "practical-administrative" sense, identifying culture with forms of making participation in culture more popular, and the cultural entities organizing this participation. In addition, it should be noted that we will be moving in the realm of 
symbolic culture, and more specifically in the realm of symbolic culture in the narrower sense outlined above. The main field of culture will be art, i.e. a form of social consciousness regulating artistic practice.

\section{Relationships between culture, cultural industries, and creative industries}

Theoretical approaches to the analysis of the commercial use of culture see this phenomenon in different ways, which leads to the variety of names it is given, such as "cultural industries", "creative industries", "leisure industries", "industries based on intellectual property rights", or "creative economy".

The concept of "cultural industries" first appeared in 1947 among the representatives of the so-called Frankfurt School in an essay titled "The Culture Industry: Enlightenment as Mass Deception" by Theodor Adorno and Max Horkheimer, and it was initially used to criticize the modern, mass approach to entertainment. The combination of the words "culture" and "industry" was used in order to shock the reader and disavow popular forms of entertainment, such as second-rate press and film, or music aimed at a mass audience. Today, the term "cultural industries" has lost its pejorative connotations, and it is used to identify those industries that "combine the creation, production and commercialization of a product with an intangible and cultural nature, where the product (its contents) is usually protected by copyright" (UNESCO 2005). These are industries which concentrate on the production of various cultural goods and services, as well as industries whose production is based on the industrial duplication of the original works of artists. Among them in the culture market we can distinguish:

- Audiovisual and film industry;

- Publishing and press industry;

- Recording industry. 
Based on the approach of the Frankfurt School, cultural industries are characterized by the following features:

- Economic perception of the product, in which it is important to ensure an adequate rate of return on investment; this economically rational condition often results in the need to avoid novelty as too unpredictable, to provide appropriate "filling" of the product with personalities known to consumers (e.g. movie stars) or to provide an adequate number of attractive special effects;

- Standardization of production associated with the concentration of producers and conducive to the economies of scale, where the increased number of manufactured products reduces their unit cost (e.g. printing books);

- Dichotomy of internal contradictions present in the product, individualization versus standardization, art versus entertainment (e.g. screening a film at the cinema);

- Continuous prolonging of the satisfaction of needs, in which the consumer receives only a semblance of the fulfillment of their expectations and is encouraged to purchase another product which might better satisfy their need for beauty or the need for artistic experience (e.g. a symphonic concert at London's Barbican Centre).

In 2011, the European Statistical Office (Eurostat) completed work on the ESSnetCulture Final Report, which sets a uniform way of estimating the contribution of entities from cultural and creative industries to the national economy, for all European Union countries. In it, the sector of cultural industries is described as a group of different areas of activity related to the production of cultural goods, which includes various forms of businesses with different mechanisms for generating revenue. The interpretation of this sector in such a way is the basis of the key document for the future cultural policy of the European Union, referred to as the Essen Declaration. This declaration, which is a summary of the conference "Culture Industries in Europe - A Comparison of Development Concepts" (the conference took place in Essen on 19-21.05.1999, during the German presidency of the $\mathrm{EU})$, identifies ten axioms defining the role of culture industries for the economies of European countries, and indicates directions for further work on policies to support their development (Table 1.1). 
Table 1.1 Essen Declaration - ten axioms for cultural industries

\section{CULTURAL INDUSTRIES}

1. Represent a distinct economic sector, whose components make up the rich mosaic of complementary sectors of the economy, which on a regional and local level make it possible to identify individual profiles. Statistical research and conventionally used categories do not include the richness and diversity of structures, as a consequence cultural industries must be treated as a separate entity in relation to economic policy, cultural policy, and urban development. Only when this condition is met, is it possible to fully appreciate the importance of cultural industries to the economy and society, employment policy, urban development, and infrastructure.

2. Are future-oriented, their characteristic feature is a high level of creativity and innovation in a market where most goods and services have no substitutes. Cultural industries have developed both in terms of content and new technologies. In key areas of employment, cultural industries require comprehensive professional training, knowledge in the field of culture and a high level of qualifications, as well as a huge commitment.

3. Can secure and create sustainable employment at regional level by generating jobs outside the public sector. Various sub-sectors of cultural industries, dominated by small and medium-sized enterprises, offer many opportunities to create new jobs. They are also strongly rooted in local environments and regional networks.

4. Can help to reinforce endogenous regional potential, because they depend greatly on traditional and cultural diversity, know-how, and innovation networks existing in towns, cities, and regions of Europe. In the age of globalization, products and services provided by these industries emphasize the regional profile and have a positive impact on the conditions underlying general economic development.

5. Deploy Europe's historic heritage in the competitive global market, Europe's greatest potential is its history and traditions. The cultural richness and diversity of Europe are the product of centuries of work of creative artists, craftsmen, technicians, and their clients. Cultural industries are based on this potential, at the same time contributing to its future development. In many areas of employment in culture-related areas, cultural industries protect the existing cultural landscape, contributing in this way to maintaining the contrast and to reducing the effects of global mass consumption.

6. Need an active culture policy, despite the fact that they promote the development of culture at a local level they are not, however, able to sell their goods or provide services in the absence of a diverse cultural environment, supported by the public sector.

7. Need an active economic policy; sectoral strategies and policies should be developed taking into account the many components of the market of the cultural industries, in order to improve the conditions for the development of cultural industries in European cities and regions. This will also contribute to the strengthening of existing structures and the development of innovative potential. Support programs should be established for new companies emerging in the sector of cultural industries, which take into account their needs and individual help should be provided to them, e.g. in the form of access to specialized information, advisory services, or capital.

8. Require support from urban-development policy; urban environments, which appeal to the international community from an employment and housing location point of view, are preconditions for the development of cultural industries. Both small and medium-sized enterprises are willing to use existing cultural heritage in their activities and programs aimed at tourists. Cultural industries strengthen the position of the centers of European cities, making them more varied and safer.

9. Require integrated urban and regional policy; a combination of simultaneous support for culture, economy, and urban areas as part of a development policy can create synergy effects in many areas of urban and regional development. The establishment of such strategies and projects will require new forms of cooperation and the creation of new partnerships for bringing these separate policy areas closer in cities and regions. With the reform of the EU's system of structural funds, the cultural sector has been granted a new status. It was decided that both on the European level and in individual Member States, more resources from the structural funds should be dedicated to promote this sector. 
10. Require a fitting context in Europe; the future development of cultural industries depends on the context, provided by a formal and legal framework and infrastructure - they must take into account the specific conditions of cities and regions, as well as the presence of open and flexible partners both in the public administration and financial sector. The trade in cultural goods and services provided by cultural industries requires a balanced level of taxation, social welfare contributions, unified legislation to protect copyright, etc. European policy can support these processes by harmonizing the legal and economic framework within which these processes occur.

Source Essen Declaration: Ten Axioms for the Culture Industries in Europe (1999)

The message from Essen regarding the economic, social and cultural importance of cultural industries has a tremendous value. It certainly showed the possibility of a new approach to the cultural sector, which is formed not only by the traditional, usually subsidized fields, but also industrial areas. It was also decided that cultural industries, like the culture on which they are based, are worthy of promotion, support, and the attention of the public authorities. The relationship between culture and cultural industries is presented in Figure 1.2.

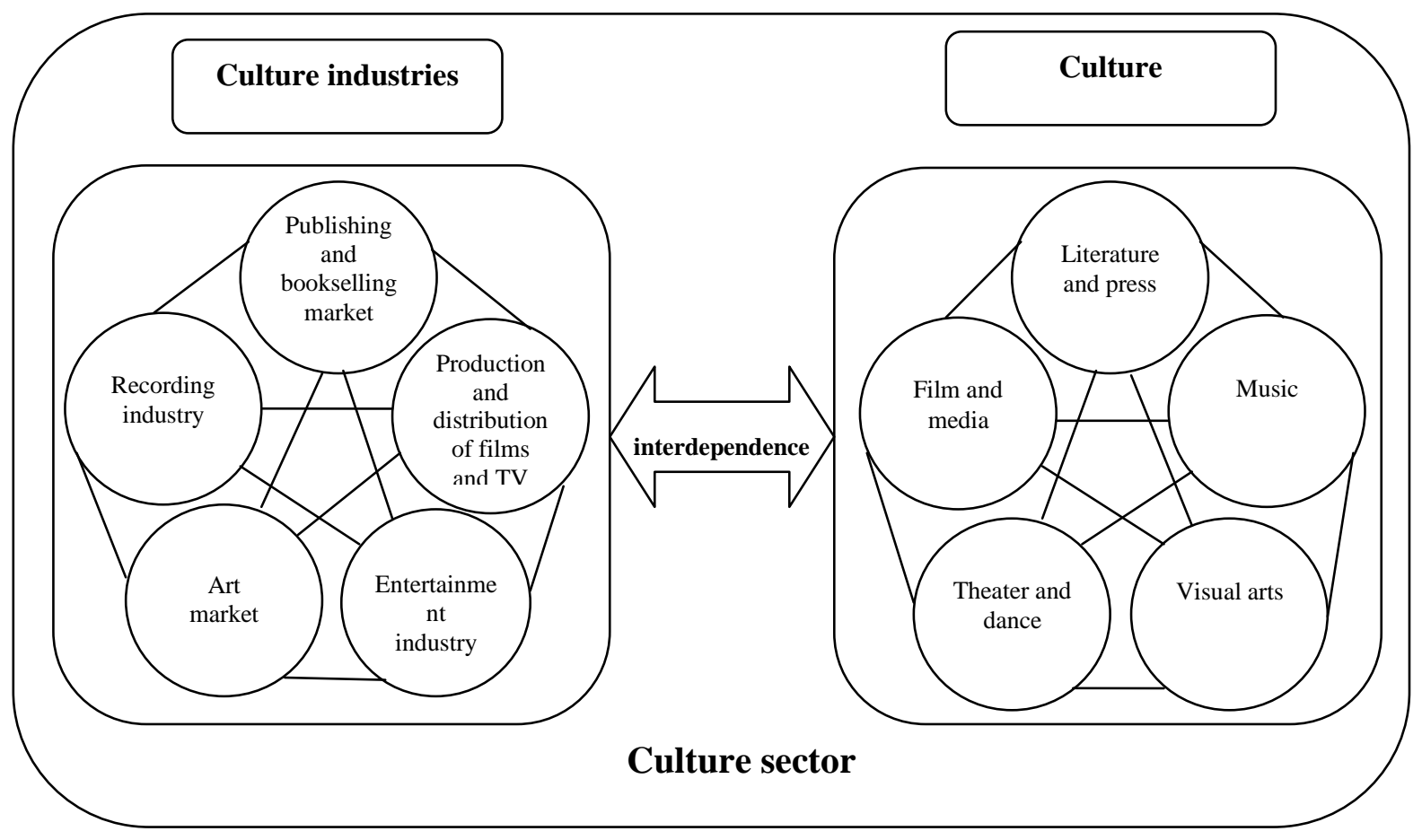

Figure 1.2 Relationship between culture and cultural industries 
Throsby (2008: 150) proposed a concentric model of cultural industries (Figure 1.3). He divided the activities of cultural industries into four circles: core artistic activity related to art (e.g. literary, artistic, musical work), other core artistic activities (e.g. activities of theaters, museums, cultural centers, concert halls), culture industries (e.g. publishing, television, radio, film festivals), and related economic activities (e.g. design, advertising, fashion).

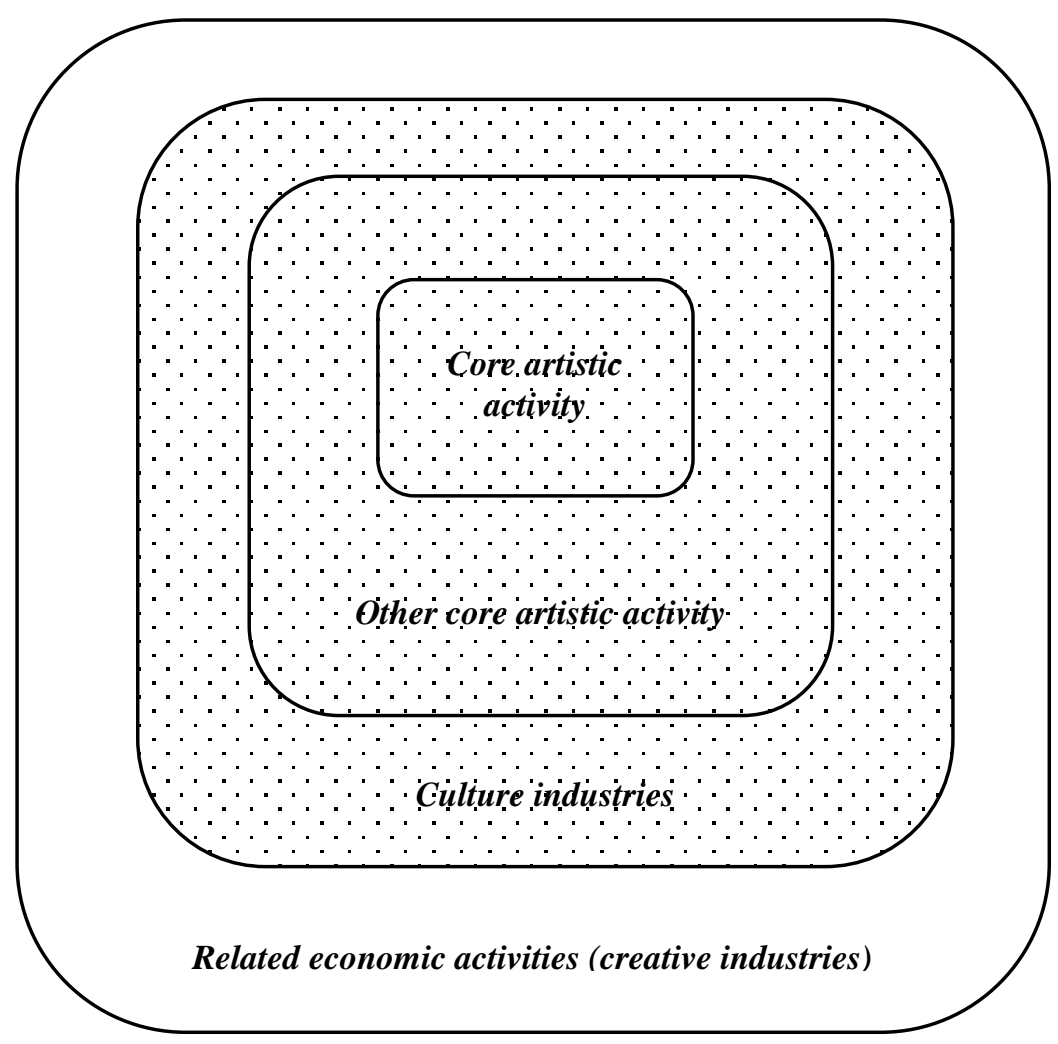

Cultural sector

Figure 1.3 Model of cultural industries by Throsby. Source Throsby (2008: 150)

The closer to the core, the higher the cultural content of products and services created within the cultural industries, as well as the greater the demand for artistic and creative engagement (labor input) from the people creating them. The core of the model are artists and basic fields of art (visual arts, performance arts, media arts, and literature) - Figure 1.4. 


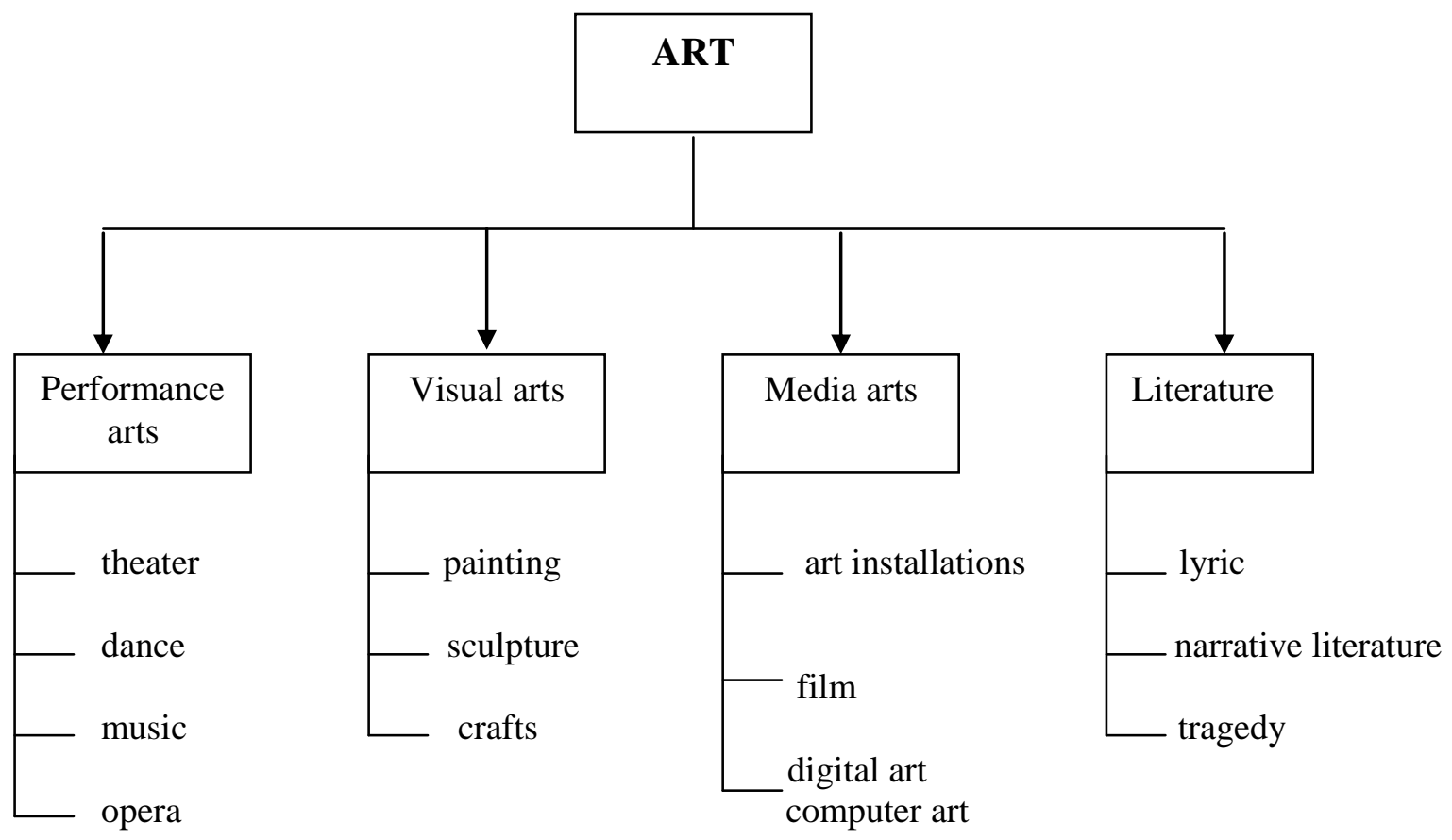

Figure 1.4 Division of art. Source McCarthy (2001), Kolb (2005)

Cultural institutions (e.g. theaters, opera houses, concert halls, museums, libraries) are listed among other core art activities. The diffusion of concepts, artistic ideas, and inspiration naturally extends from the core outward, reaching the related economic activities, and eventually to creative industries, distinguised from cultural industries (Table 1.2).

Table 1.2 Categorization of culture, cultural industries and creative industries

\begin{tabular}{|c|c|c|}
\hline Sector & Industry & Characteristics \\
\hline \multicolumn{3}{|c|}{ Core. Area of art } \\
\hline Visual arts & $\begin{array}{ll}\text { - } & \text { craft } \\
\text { - } & \text { painting } \\
\text { - } & \text { sculpture } \\
\text { - } & \text { photography } \\
\end{array}$ & $\begin{array}{l}\text { Usually not economic activity, its } \\
\text { products are prototypes or } \\
\text { products potentially protected by } \\
\text { copyright. }\end{array}$ \\
\hline Performance arts & $\begin{array}{ll}\text { - } & \text { theater } \\
\text { - } & \text { dance } \\
\text { - } & \text { music } \\
\text { - } & \text { opera } \\
\text { - } & \text { circus } \\
\end{array}$ & \\
\hline Media arts & $\begin{array}{ll}\text { - } & \text { film } \\
\text { - } & \text { electric installations } \\
\text { - } & \text { digital art, computer art } \\
\end{array}$ & \\
\hline Literature & $\begin{array}{ll}\text { - } & \text { lyric } \\
\text { - } & \text { narrative literature } \\
\text { - } & \text { tragedy }\end{array}$ & \\
\hline
\end{tabular}




\section{Circle 1. Other core artistic activity}

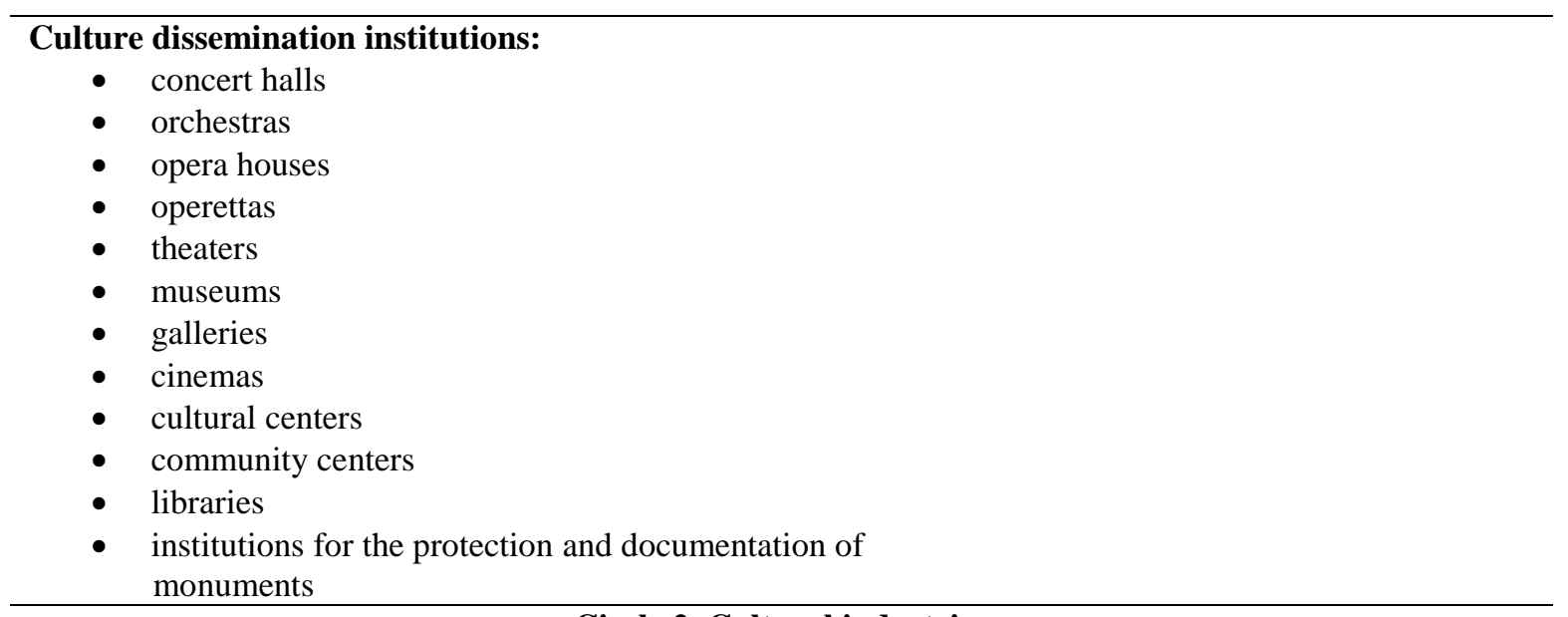

Circle 2. Cultural industries

\begin{tabular}{|c|c|c|}
\hline \multicolumn{2}{|c|}{ Film and video } & The circle includes economic \\
\hline \multicolumn{2}{|c|}{ Television and radio } & activities aimed at mass \\
\hline \multicolumn{2}{|c|}{ Video games, computer games } & reproduction, whose products are \\
\hline Music & $\begin{array}{ll}\text { - } & \text { recorded music market } \\
\text { - } & \text { live music } \\
\text { - } & \text { management of copyright in music }\end{array}$ & \\
\hline $\begin{array}{l}\text { Books and } \\
\text { newspapers }\end{array}$ & $\begin{array}{ll} & \text { book publishing } \\
\text { - } & \text { publishing of newspapers and } \\
\text { magazines }\end{array}$ & \\
\hline
\end{tabular}

Circle 3. Creative industries

\begin{tabular}{|c|c|c|}
\hline Design & $\begin{array}{ll}- & \text { fashion } \\
\text { - } & \text { graphic design } \\
\text { - } & \text { interior design } \\
\text { - } & \text { product design } \\
\end{array}$ & $\begin{array}{l}\text { Not necessarily economic in } \\
\text { nature, often providing prototypes; } \\
\text { products are protected by } \\
\text { copyright. }\end{array}$ \\
\hline \multicolumn{3}{|l|}{ Architecture } \\
\hline Advertising & & \\
\hline
\end{tabular}

Creative industries consist of ventures in which culture becomes a "creative" contribution to the production of goods which are classified into branches not directly related to culture. These are activities such as design (fashion design, interior design, industrial design), architecture, and advertising. It is assumed that in modern societies, creative industries are the fastest growing segment of the market of social goods and services. It is estimated that in the United States, this market (audiovisual sector, consumption of cultural industries, software, fashion, graphic design, and others) represents more than $50 \%$ of the 
entire market. The very notion of "creative industries", however, is relatively new and research concerning this sector is also a new field. The term has been used since the end of the twentieth century, and was popularized in 2000 by Richard Caves. The very title of his book Creative Industries: Contracts between Art and Commerce indicates that creative industries operate at the interface between cultural activities and business. The concept of creative industries is a broad category that includes the arts, cultural institutions, cultural industries, and other types of creative activity, including industries using new technologies (e.g. new media) in creative activities. The boundaries of this concept are determined by the understanding of creativity and innovation. At the widest point they are blurred and it is not possible to differentiate between creative industries and other types of intellectual activity containing elements of creativity and innovation, including scientific and technological innovation. The category of leisure time places cultural industries within the narrow definition of culture as art. However, the field of creative industries (a wider category than cultural industries) also includes products that meet the conditions described above, the consumption of which however is characteristic not only of leisure time, but also of activities pursued only partly during leisure. Due to focus on profit, new types of media, privatizing consumption, belonging to the sphere of entertainment rather than to art, or due to other reasons, these products go beyond the traditional fields of art and activities of cultural institutions.

The definition adopted by the Department for Culture, Media and Sport (DCMS) for creative industries acknowledges those areas of business activity in which individual creativity is the main input in the production process, and intellectual property is a characteristic of the product which is the result of this creativity (Figure 1.5). 


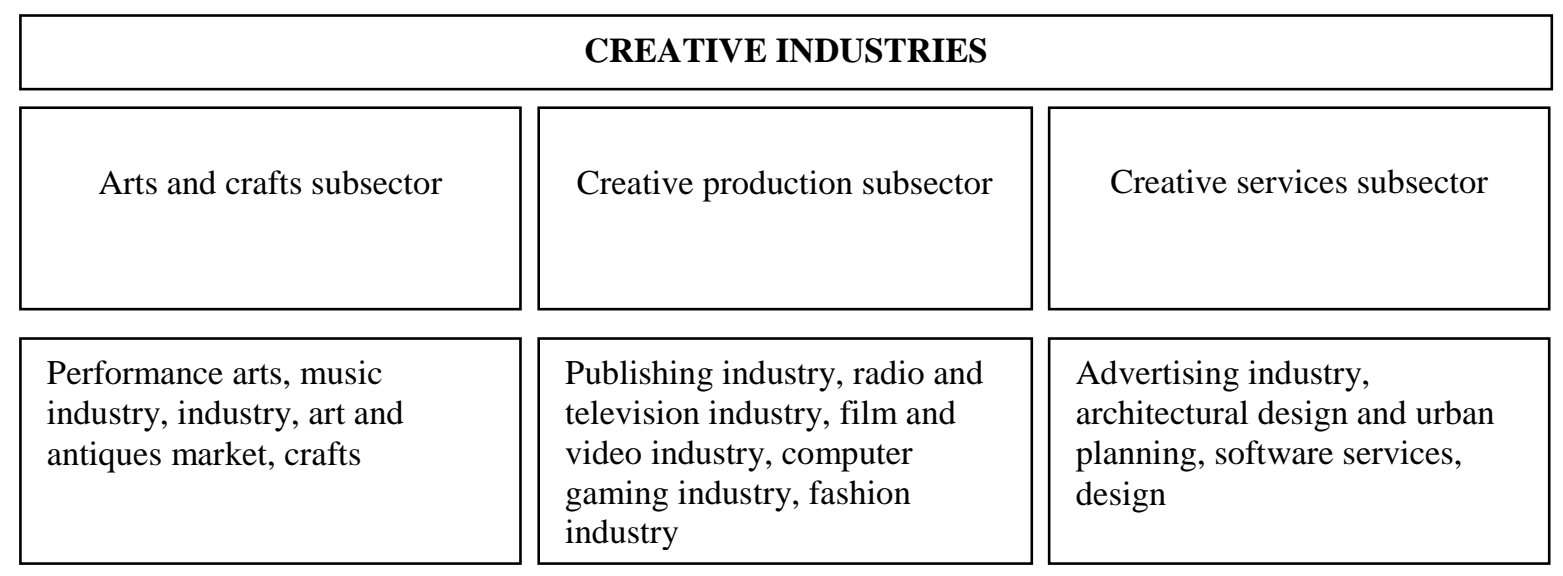

Figure 1.5 Typology of creative industries according to DCMS. Source Department for Culture, Media and Sport (2001)

The definition of creative industries adopted by the European Statistical Office (Eurostat) is based on two definitions:

- cultural industry enterprises are enterprises producing and distributing goods and services, which at the moment of their development are considered as having specific attributes, uses, or purpose which embodies or conveys cultural expression, irrespective of their commercial value (EU Commission 2010);

- creative industries and cultural industries are industries involved in the creation and supply of market products and services, which result from the cultural and creative contribution which gives them their value (Power and Nielsen, 2010: 3). The area of the creative sector consists of ten domains of culture: national heritage, libraries, archives, books and press, visual arts, performance arts, multimedia and audiovisual arts, architecture, advertising, and crafts.

These areas encompass activities varying in terms of their economic function in the areas of creation, production, publication, distribution, sales, maintenance, education, management, and control. Thus, according to Eurostat's definition, the cultural sector can be seen in broad terms (core activities, other core artistic activities, culture industries, and creative industries) as a collection of all the entities which are players in this sector (Table $1.3)$. 
Table 1.3 Institutional typology of the culture sector - in the broad definition

\section{LOCAL GOVERNMENT}

Largely responsible for the program of public services in the cultural sector, coordinating development strategies, financing cultural activities, and territorial marketing. The local area of cultural development depends on the local government's efficiency and effectiveness. It is usually heavily involved in the development of the local economy.

\section{CULTURAL INSTITUTIONS FINANCED BY LOCAL OR CENTRAL BUDGET}

Responsible for the implementation of the program of public services in the field of culture, they organize cultural activities and generate the circulation of culture around themselves through various partnerships, in cooperation with private parties and non-governmental organizations. Creating cultural capital through cultural education, they stimulate the potential for the development of cultural services.

\section{PRIVATE ENTITIES (COMPANIES, ENTERPRISES)}

They form a very important part of the cultural sector as they are actual businesses, creating the most jobs, inspiring innovation, stimulating increasingly advanced needs for the development of the educational system, attracting the so-called creative class. We can specify the following industries: film, video and audiovisual production industry; music industry; publishing industry; media industry (television, radio, newspapers, Internet); advertising industry; graphic design and industrial design; fashion design; architecture; performing arts; activities of artists and crafts; galleries and art trade; preservation of monuments and works of art; computer games and software; private cultural institutions (coffee shops, cultural centers, music clubs). We could even add the tourism industry (travel agencies, hotels, conference centers and convention centers, restaurants, amusement parks, services related to active tourism, cultural route operators).

\section{NON-GOVERNMENTAL ORGANISATIONS}

They form a large part of the cultural sector. The variety of forms and the range of activities, the interdisciplinary character of projects and the combination of commercial and social goals, are wideranging. Organizations function as corporations or as small entities established for a single project, remaining dormant until the next project. Foundations and associations form the densest network of cultural entities (creative industries are harder to find outside metropolises) with the highest number of cultural projects and number of people involved (staff and volunteers). NGOs acquire very large external financial support from EU and national funds.

\section{BUSINESS SUPPORT ENTITIES}

These include many varied institutions which provide developmental support. They include technology parks, investment zones, development incubators, economic development agencies, cluster initiatives, technology transfer centers, training institutions, chambers of commerce, and special purpose funds. Equally important are 3rd sector support institutions (volunteer centers, NGO incubators, specialized systemic foundations). Some of them are set up especially for the development of the cultural sector. Local Action Groups can be an example of this type of institution.

\section{RELIGIOUS COMMUNITIES}

They are significant cultural entities. They organize social activities, organize education, are associated with the development of cultural and pilgrimage tourism, and take care of a large number of historic buildings and monuments.

\section{SCHOOLS AND EDUCATIONAL INSTITUTIONS}

These entities may also fall within the scope of the cultural sector. Art schools are of particular importance. The development of education will strengthen the presence of culture in this system (this may be reflected in the development of cooperation with artists, after-school education, or new courses in the field of cultural education). 


\section{HIGHER EDUCATION INSTITUTIONS}

Higher education institutions (including the faculties of humanities, social sciences, management, education) and art universities are an important sub-system of the cultural sector. They run libraries, and museums and research institutions operate within them. A very large part of their activities can be considered cultural. Above all, they are concerned with the education of cultural personnel including artists, organizers, managers of culture, and specialists in the cultural sector.

\section{NATURE CONSERVATION INSTITUTIONS}

National parks or landscape parks are also part of the cultural sector. In addition to nature conservation, their duties include the protection of cultural heritage, and the management of museums and educational facilities. They are the "backbone" for the development of cultural and nature tourism, and wildlife is a cultural resource.

\section{NATURAL PERSONS AND LEGAL ENTITIES MANAGING MONUMENTS}

Natural persons and legal entities that own or manage monuments can form a separate group. Their protection generates revenue in the conservation sector. They include popular tourist attractions. Monuments are often transformed into profitable ventures within the leisure industry (hotels, conference centers, private museums, fashionable residential buildings).

\section{INFORMAL GROUPS}

Informal groups are for example artist groups, special interest groups, local activity groups, or informal associations. In order to operate, they spend money in "cultural needs shops" such as bookstores, shops for musical instruments or board games, and shops with accessories for allotments or tourism. They represent a huge market of needs within the cultural sector. New cultural businesses and NGOs also derive from here.

One of the approaches to the cultural sector (culture, cultural industries, and creative industries) is the use of the concept of a value chain, introduced to describe economic processes by Michael Porter in 1985. With respect to the creative industries, the value chain starts with artists and cultural institutions, expands further through various manufacturers and distributors of cultural products, and ends with the recipients, i.e. the broadly defined audience. In an ideal case, each link in the chain forms a kind of added value, making the product better adapted to the recipient. In reality, however, it is possible that the value is subtracted from, rather than added to, in the value chain. An example of a value chain in the music industry is shown in Figure 1.6. 


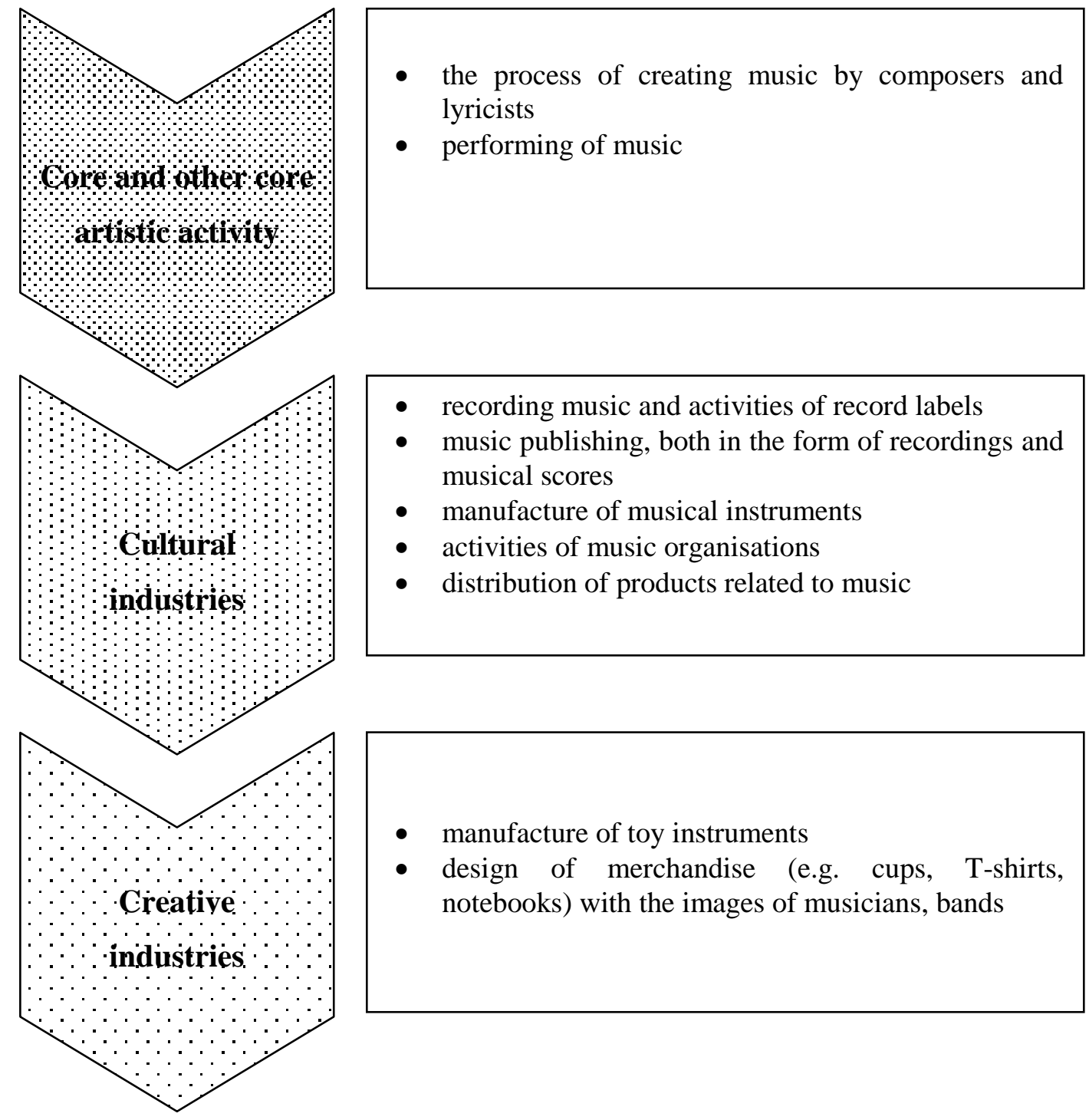

Figure 1.6 Value chain in the music industry

This approach assumes the commercialization of cultural production, which - in most cases means that mass production is assumed. The relationships between culture, cultural industries, and creative industries are shown in Figure 1.7. 


\begin{tabular}{|c|c|}
\hline \multicolumn{2}{|c|}{ INDIVIDUALS ARTISTS/CULTURAL INSTITUTIONS } \\
\hline $\begin{array}{c}\text { Artistic creativity } \\
\text { (e.g. literary, visual art, musical creativity) }\end{array}$ & $\begin{array}{c}\text { Activities of cultural institutions } \\
\text { (e.g. theaters, opera houses, concert } \\
\text { halls, museums, libraries, cultural } \\
\text { centres) }\end{array}$ \\
\hline \multicolumn{2}{|c|}{ CULTURAL INDUSTRIES } \\
\hline 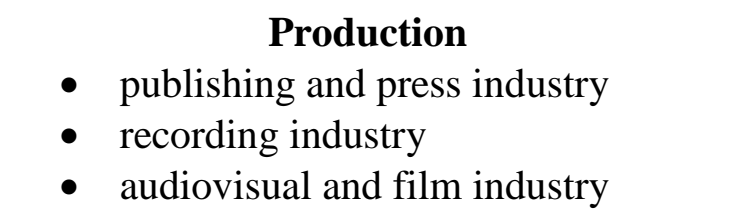 & $\begin{array}{l}\text { Distribution } \\
\text { (e.g. distribution and sale of newspapers, } \\
\text { books, CDs, DVDs, distribution, display } \\
\text { of films, trading in antiques) }\end{array}$ \\
\hline \multicolumn{2}{|c|}{ CREATIVE INDUSTRIES } \\
\hline $\begin{array}{c}\text { Production, creativity } \\
\text { (e.g. specialised design - design, software } \\
\text { development - computer games, } \\
\text { multimedia, photographic services, } \\
\text { manufacture of toys) }\end{array}$ & $\begin{array}{c}\text { Distribution, promotion } \\
\text { (e.g. advertising - advertising agencies, } \\
\text { news agencies, organisation of trade } \\
\text { fairs, conferences, exhibitions) }\end{array}$ \\
\hline
\end{tabular}

Figure 1.7 Relationship between culture, cultural industries, and creative industries. Source Kasprzak (2013: 43)

The World Intellectual Property Organization (WIPO) introduced the concept of a creative sector. According to WIPO, the creative sector means all the industries whose activities encompass the creation, production, manufacture, performance, broadcasting, exhibition, distribution, and sale of goods protected by copyright. They therefore include: press and literature, music, theater production, opera, radio and television, photography, software, visual arts, advertising services, and copyright and collective management societies (WIPO 2003). In turn, the Economy of Culture in Europe report released by KEA European Affairs in 2006 proposed the division of the creative sector into the cultural sector and creative industries. The cultural sector includes:

- Non-industrial sector - producing non-reproducible goods and services (concerts, art fairs, exhibitions, etc.). These are primarily the fields of arts (such as visual arts - 
painting, sculpture, crafts, photography; art and antiques markets; performance arts opera, orchestras, theater, dance, circus and heritage, including museums, historic and archaeological sites, libraries and archives; and

- The industrial sector - producing goods and cultural services on a massive scale (e.g. books, films, music recordings). These include cultural industries such as audiovisual production, video games, television and radio, recording industry, book and press publishing.

Due to the very wide diversity of entities in the cultural sector, this paper will use the concept of the cultural sector in its narrow sense. In this case it will mean core artistic activities, other core artistic activities, and cultural industries (Figure 1.3), as distinguished by Throsby.

\section{Typology of cultural institutions}

The concept of a "cultural institution" can be considered in a narrow or broad sense. The first of these approaches includes institutions creating and disseminating works of art dedicated to the art of interpretation (philharmonic orchestra, opera, operetta, theater, etc.), visual arts (art galleries, museums, etc.), libraries, and cultural heritage. In the broad sense, this concept also covers so-called cultural industries (e.g. film studios, cinemas, mass media, radio, television).

Depending on the mission of a cultural institution, it may fulfill different functions: creation, production, reproduction, dissemination, or storage. Various combinations of these functions are also possible, depending on the goals of the mission; e.g. some theaters are involved in the creation of art, its presentation, and dissemination, while others focus on promotion and sale (Mazurek-Łopacińska 1997: 92, Lehman and Wickham 2014). A characteristic trait of cultural institutions is their great diversity in terms of size, structure, and the fields they represent. From the marketing point of view, it is important to divide the entities in the cultural sector according to the focus on the product or market (Figure 1.8). 


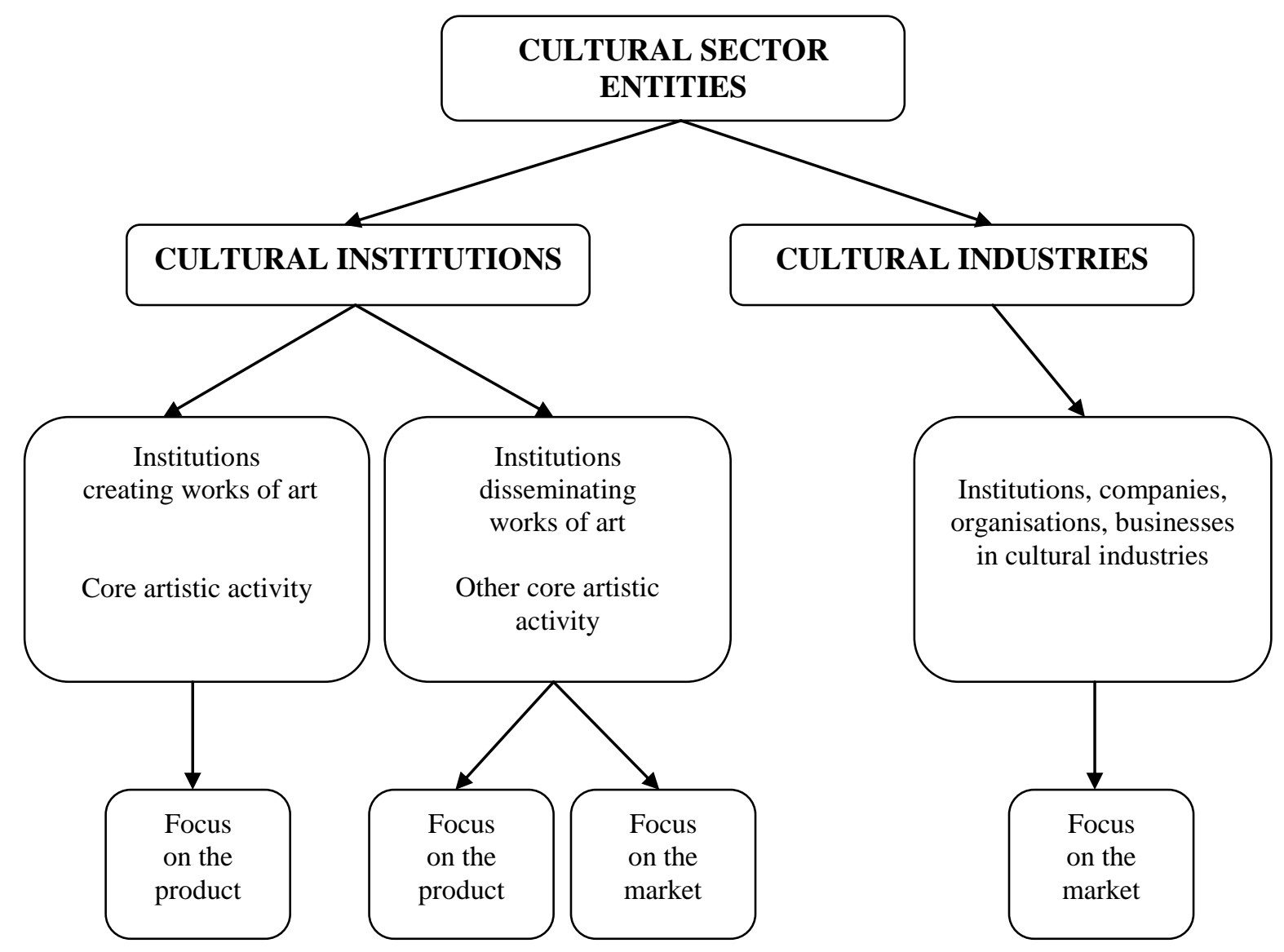

Figure 1.8 Division of cultural institutions on the grounds of their marketing focus

Focus on the product means placing it at the center of attention of a cultural institution, and examples could be: early music, contemporary art museums, one-man theater festivals. Focus on the market consists of building and addressing the cultural offer to the needs and expectations of customers (e.g. symphonic concerts of the Dutch virtuoso violinist Andre Rieu).

As entities belonging to the cultural sector, this paper primarily refers to the public, to private and mixed cultural institutions and companies, and to businesses and organizations focused on the production of various cultural goods and services whose production is based on the industrial duplication of the original works of artists (Figure 1.8). 


\section{Culture and its industries as a factor stimulating socio-economic development}

Estimates of the contribution of the cultural sector to the economy have been conducted by many organizations. For example, according to the World Bank, in developing societies the cultural sector helps to create new opportunities to generate income through knowledge and cultural production. The role of the cultural sector, in the view of the World Bank, is to catalyze regional development, to contribute to the development of tourism, and to strengthen social capital as well as human capital. By recognizing the role and importance of this sector, the World Bank undertakes actions to incorporate cultural factors in credit strategies and engages in cultural projects, e.g. in the field of cultural heritage in countries taking loans (World Bank 1999: 15). On the other hand, according to the calculations of the European Commission, the economic dimension of the cultural sector is expressed in the creation of $2.6 \%$ of the EU's GDP, and in the rate of development which is higher by more than 12\% than the rate of development of the EU economy overall (Kem et al. 2011: 4). In addition, the cultural sector provides $1.7 \%$ of all jobs in the European Union - among the European countries, the highest share of employment in the cultural sector can be observed in Iceland, Norway, Denmark, Finland, Sweden, and Latvia, the lowest in Romania and Portugal (Cultural Statistics 2011). Figure 1.9 presents the proportion of people employed in the cultural sector in relation to total employment in European countries. 
Łukasz Wróblewski: Culture Management. Strategy and marketing aspects

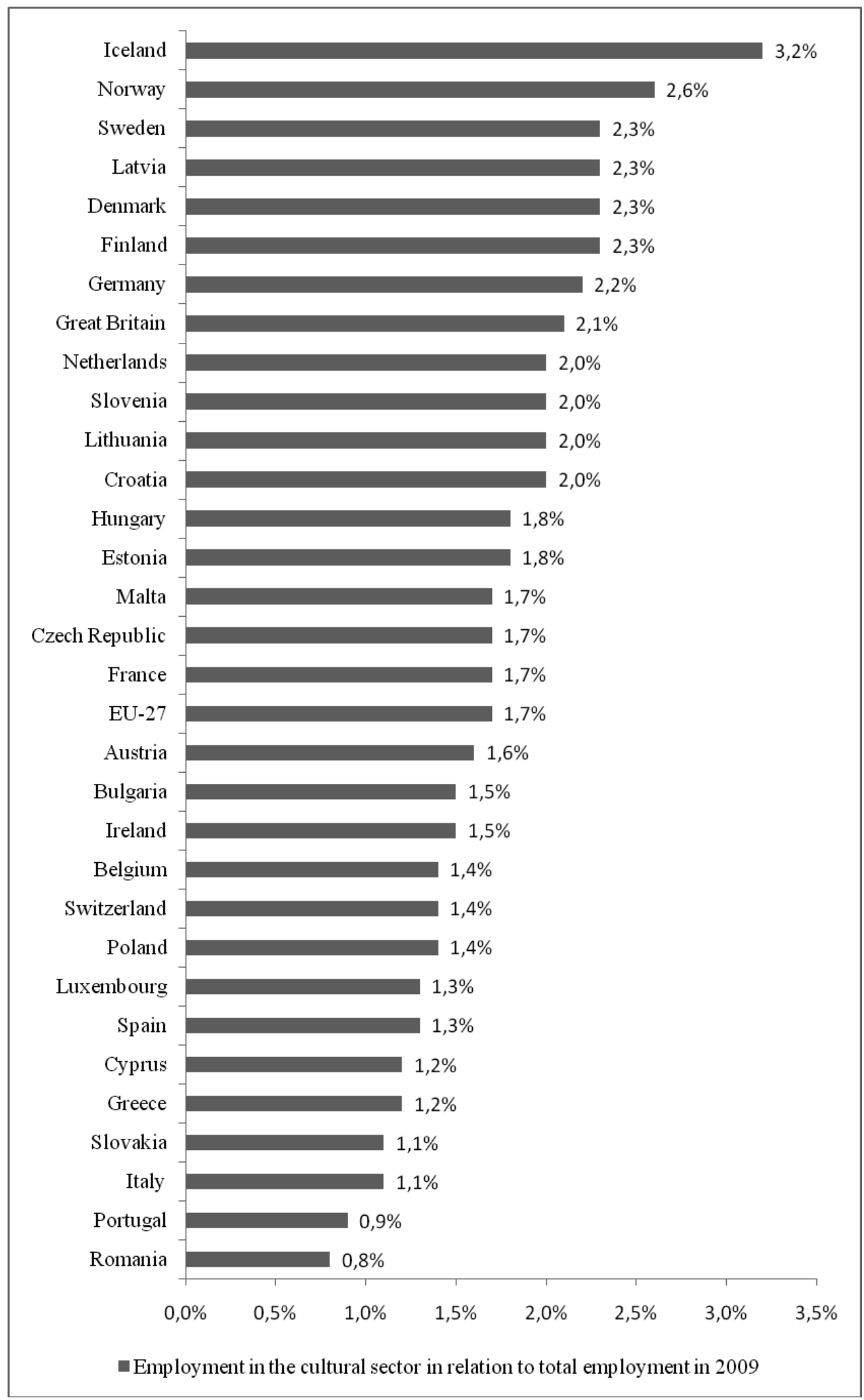

Figure 1.9 Proportion of people employed in the cultural sector in relation to total employment in European countries in 2009. Source Cultural Statistics (2011: 67)

38 Logos Verlag Berlin - Academic Books for Sciences and Humanities 
The growing importance of the cultural sector in national (and regional) economies has an impact on both the development of entrepreneurial and creative behaviors of the inhabitants of the region and on the improvement of its competitive position. It also increases the attractiveness of the country or the region for present and future residents, tourists, and investors. The cultural sector has become an engine of growth, analogous to agriculture in the 1920s, industry in the fifties and sixties, and the telecommunications and IT sector in the last two decades. Culture and its industries are therefore a generator of new solutions that penetrate into other sectors of the economy, and are adapted or modified there (Smoleń 2003, Morozova et al. 2016).

The importance of culture and the impact of cultural industries on socio-economic development can be analyzed from different points of view. Assuming a wide impact of culture, we may identify the following significant and major planes of impact of culture and cultural industries on economic development (Wróblewski 2016, Kasprzak 2007, 2013):

- A direct impact on the labor market by creating jobs friendly to the environment, based on knowledge and high technology - due to its innovation and the constant production of new goods and services, the cultural sector is now one of the fastest growing sectors of the labor market;

- Creating products for other sectors (branches of industry), which contributes indirectly to increasing the number of jobs in sectors complementary to the cultural sector - tourism, recreation, education. Culture, in fact, works for other sectors. An example would be national heritage, which in many countries, including the less developed ones, is an engine for the development of the tourism industry;

- Increasing the revenues of local or regional budgets directly through the sale of cultural goods and services in the internal and external markets, and indirectly through property taxes, income tax from individuals and companies, and profits generated in complementary industries;

- Investment attractiveness of the region (the Bilbao effect);

- An element of renewal and revitalization of urban and rural space and industrial facilities. Revitalization helps to improve the quality of life of the residents, restoring spatial order and the economic recovery and reconstruction of social bonds; 
- Help in creating a positive image of the region or the entire country;

- Increasing the level and quality of life which is reflected in the attractiveness of the place of residence, helps to attract and retain highly-qualified, creative people;

- A way to combat the so-called urban disease - the weakening of social ties.

An increase in individual income and an increase in the turnover of businesses results in the fact that local or state budgets experience higher tax revenues. Research in this area shows that culture and cultural industries, especially tourism motivated by cultural activities, promotes prosperity, creates additional economic activity, activates other industries, affects the real estate market, and encourages the development of infrastructure.

Estimating the impact of the cultural sector on socio-economic development is extremely difficult and requires an inquiry into the effects of what investing in culture (the cultural sector) brings to the economy. The source literature notes a rather obvious fact: that the positive effects of "investing" in culture are long-term. However, they rarely appear immediately after incurring expenditure, and are therefore more difficult to observe and evaluate. The evaluation of these relationships requires the following conditions to be met (Ilczuk 2007):

- A detailed examination of the structure of the cultural sector, establishing a list of institutions, business entities and other stakeholders, identifying the interdependencies between them and the relationship between cultural institutions and the rest of the economy; it is also important to understand the potential boost to the economy, which may have its origin in the operation of cultural entities (cultural institutions, businesses in cultural industries);

- The identification and selection of appropriate methods by which we can explore the direction and the impact of cultural entities and related events on economic, social, and cultural life;

- The existence (collection) of statistical data that would allow the use of available methods (the smaller the region under examination, the more difficult this condition is to apply, if only because of the lack of aggregation of certain data). 
The most tangible result, though often difficult to precisely evaluate, is the fact that a new demand and an inflow of new capital (and/or retention of local capital in the region or country) has appeared. An equally obvious effect is the creation of new jobs, which consequently increases the income of the population. 


\section{References}

Caves R.E. (2000), Creative industries: Contracts between art and commerce, Harvard University Press, Cambridge

Creative Industries Mapping Document (2001) Department for Culture, Media and Sport, London

Culture and Sustainable Development: A Framework for Action (1999), World Bank, Wahington, http://wwwwds.worldbank.org/external/default/WDSContentServer/WDSP/IB/2005/12/16/000011823_

200051216164532/Rendered/PDF/34671.pdf (accessed 14 June 2014)

Cultural Statistics (2011), Publications Office of the European Union, Luxembourg

Essen Declaration: Ten Axioms for the Culture Industries in Europe (1999), EU Presidency Conference:

Culture industries in Europe - A Comparison of Development Concepts, Essen

Grad J., Kaczmarek U. (2005), Organizacja i upowszechnianie kultury w Polsce, Wydawnictwo Naukowe

UAM, Poznań

Guide on Surveying the Economic Contribution of Copyright-Based Industries (2003), WIPO Publications

Ilczuk D. (2012), Ekonomika kultury, PWN, Warszawa

Kasprzak R. (2007), 'Kultura i przemysły kultury - nowy paradygmat rozwoju region’, in Karwowski J. (ed.)

Ustugi w rozwoju regionu - wybrane problem, Uniwersytet Szczeciński, Szczecin, pp. 181-188

Kasprzak R. (2013), Przemysty kreatywne w Polsce. Uwarunkowania i perspektywy, Wydawnictwo Kamon

Consulting, Warszawa

Kern P., Smits Y., Wang D. (2011), Mapping the Cultural and Creative Sectors in the EU and China: A working Paper in Support to the Development of an EU-China Cultural and Creative Industries. (CCIs) Platform, Brussels

Kłoskowska A. (1983), Kultura masowa, PWN, Warszawa

Kmita J. (1982), O kulturze symbolicznej. Centralny Ośrodek Metodyki Upowszechniania Kultury, Warszawa

Kolb B.M. (2005), Marketing for Cultural Organizations: New strategies for attracting audiences to Classical Music, Dance, Museums, Theater and Opera, Thomson Learning, London

Kroeber A., Kluckhohn C. (1952), 'Culture: A Critical Review of Concepts and Definitions', Papers of the Peabody Museum, Cambridge

Lehman K., Wickham M. (2014), 'Marketing orientation and activities in the arts-marketing context:

Introducing a Visual Artists' Marketing Trajectory model', Journal of Marketing Management, pp. 1-33, doi:10.1080/0267257X.2013.838987

Mazurek-Łopacińska K. (ed.) (1997), Kultura w gospodarce rynkowej, problemy adaptacji marketingu. Wydawnictwo Akademii Ekonomicznej im. Oskara Langego we Wrocławiu, Warszawa-Wrocław

Morozova O., Nozdrenko E., Zhukovskaya L., Kostylev S. (2016), 'Management and art-management: dimensions of conceptual interaction', Economic Annals-XXI, Vol. 158(3-4(2)), pp. 61-65, doi:10.21003/ea.V158-14 
Power D., Nielsén T. (2010), Priority Sector Report: Creative and Cultural Industries - Methodological Appendix. Raport przygotowany w ramach inicjatywy Europe INNOVA dla European Cluster Observatory, http://www.europe-innova.eu/c/document_library/get_file?folderId=261559\&name=DLFE-10734.pdf (accessed 12 April 2014)

Słownik języka polskiego (1995), PWN, Warszawa

Smoleń M. (2003), Przemysty kultury - wplyw na rozwój miast, Wydawnictwo Uniwersytetu Jagiellońskiego w Krakowie, Kraków

Sobocińska M. (2015), Uwarunkowania i perspektywy rozwoju orientacji rynkowej w podmiotach sfery kultury, Wydawnictwo Uniwersytetu Ekonomicznego we Wrocławiu, Wrocław Szczepański J. (1965), Elementarne pojęcia socjologii, PWN, Warszawa

The Economy of Culture in Europe, Study Prepared for the Eurpean Commission (2006), KEA European Affairs, Turku School of Economics, MKW Wirtschafts-forschung

Throsby D. (2008), Ekonomia i kultura, Narodowe Centrum Kultury w Warszawie, Warszawa

Unlocking the potential of cultural and creative industries (2010), in Green Paper COM (2010) 183, EU

Commission, Brussels

Wróblewski Ł. (2012), Strategie marketingowe w instytucjach kultury, PWE, Warszawa

Wróblewski Ł. (2016), Marketing strategiczny w sektorze kultury Euroregionu Śląsk Cieszyński, Wydawnictwo CeDeWu, Warszawa 



\section{Chapter 2}

\section{Conditions for the development of marketing in organizations in the cultural sector}

\section{Conditions for the application of marketing in culture and cultural industries}

In literature on marketing, next to the concept of classical marketing, a rather significant amount of material from the point of view of methodological values (where the differentiating factor of marketing is striving to meet customer needs and creating their satisfaction as a basis for achieving the company's objectives) is dedicated to the concept of strategic marketing, relationships, services, values, experiences, and territorial marketing. These concepts, without major modifications, have been adopted in commercial organizations and have also been widely applied in cultural industries. Nevertheless, relatively few authors have analyzed their application in the field of culture, which Thorsby classified as core or other core artistic activity. In addition, representatives of cultural institutions often do not recognize, or are opposed to, the use of marketing tools. They mistakenly equate marketing with selling, thinking that such methods reduce the value of the activities in which they engage. They believe that their products should not require a commercial approach. As explained by Diggles (1984: 18), there was a religious school of thought which considered art to be sacred, with God as the audience, and that all attempts to influence its range are a profanation. Meanwhile, there are many reasons which support adapting marketing concepts to the area of culture. They are related to the complexity of changes which occur in the environment of cultural institutions, and to the search for new approaches to the management of entities in the cultural sector. The first public discussion 
on the usefulness of marketing - the concept of classical marketing - in cultural institutions began in the late 1960s with the work of Kotler and Levy (1969). According to them, marketing can go beyond its narrowly perceived role in commercial organizations and gain a broader social significance. They believed that the use of marketing in the cultural sector is necessary due to increasing competition not only in the sector itself, but also in related sectors, for example in entertainment and tourism. Consequently, this implies the need for shaping positive attitudes towards culture and creating a model of spending free time in which art (the cultural offer) occupies an important position. In this perspective, Kotler and Levy (1997: 23) have defined marketing as satisfying human needs with sensitivity. Thus, in the cultural sector, marketing is concerned with facilitating the exchange of services between a cultural entity and consumers so that certain social needs can be met. Therefore, certain questions are raised: whose needs does a cultural entity aim to meet? Can we talk about its customers? Kotler and Levy have no doubts in this regard. The authors believe that all organizations have customers, regardless of whether they call them so or not. The public, of course, constitutes the typical group of customers of a cultural institution. However, donors, suppliers, artists, staff, volunteers, cultural foundations, and other entities should not be forgotten. Of course, it would be an oversimplification to think that marketing concepts and tools can be "blindly" applied to cultural institutions, without any modifications. In the cultural sector (especially the part identified with core and other core artistic activities), there should be a balance between attitudes towards culture, which include the claim that culture has its own inherent value which must be protected at all costs, and the views of people who think that, just like any other form of human activity, culture must pay for itself, and it is therefore essential to take the available audience into account. We must keep in mind that the mission of many cultural institutions (e.g. theaters, operas, museums, and concert halls) is seeking various forms of expression. Therefore, not only concerts and performances which are known to have the support of the community are performed (see Kolb 2005, Schroeder 2005, Rentschler and Shilbury 2008, Boorsma and Chiaravalloti 2010, Jyrama and Ayvari 2010, O’Reilly 2011, Fillis 2011, Lehman 2014, Colbert and St-James 2014).

We should also look at the reasons for implementing different marketing concepts in culture with reference to the ongoing lifestyle changes of the consumers of the cultural 
offer. In addition, an important role is played by the internationalization of the circulation of cultural goods and services, as well as by the problems with introducing products that have been created outside the so-called broadcasting centers (e.g. the Hollywood cluster) into global circulation. At the same time, among the reasons to implement marketing concepts in the cultural sector, the development of information and communication technologies plays an important role, triggering new opportunities for creating and distributing cultural goods and services, and communicating the related values to consumers of culture. Ongoing technological development changes the position of cultural players in the market. Given the fact that marketing is a multi-paradigmatic category, there are specific grounds for the implementation of various marketing concepts by entities in the cultural sector (Table 2.1).

Table 2.1 Reasons for adapting and implementing marketing concepts in the cultural sector

\begin{tabular}{|c|c|}
\hline $\begin{array}{l}\text { Type of } \\
\text { concept }\end{array}$ & lapting and implementing marketing concepts in the cultural sector \\
\hline $\begin{array}{l}\text { Classical } \\
\text { concept of } \\
\text { marketing }\end{array}$ & $\begin{array}{l}\text { - The main premise for implementing marketing concepts in the cultural sector is the } \\
\text { need to increase the scope of participation in culture } \\
\text { Modification of the classical concept of marketing resulting from the functions } \\
\text { performed by the cultural sector is expressed in the formulation of a principle, } \\
\text { according to which the role of marketing is to find the right audience for the products } \\
\text { created by artists, not to create products according to customer needs } \\
\text { - Understanding the behavior of participants in culture and their conditions, closely } \\
\text { related to the approach focused on the market, allows entities in the cultural sector to } \\
\text { achieve their goals because not only does the audience need artists and their works, but } \\
\text { the artists also need an audience } \\
\text { - Striving to build customer satisfaction is not in contradiction with a high quality of } \\
\text { artistic works }\end{array}$ \\
\hline $\begin{array}{l}\text { Concept of } \\
\text { strategic } \\
\text { marketing }\end{array}$ & $\begin{array}{l}\text { - Long-term development strategies for the cultural sector are formulated at the national } \\
\text { or regional level, as well as development strategies for the country and the region, } \\
\text { which contain references to culture and its industries } \\
\text { - There is a high potential for this concept from the standpoint of the management of } \\
\text { entities in the creative sector, especially transnational media corporations which are } \\
\text { considered to be part of the cultural industries } \\
\text { - There is a need for market segmentation due to an increase in the diversity of behavior } \\
\text { among culture participants } \\
\text { Implementation of the principles of strategic marketing by cultural institutions can } \\
\text { increase their chances of attracting donors who expect a long-term perspective to be } \\
\text { included in the management of cultural institutions } \\
\text { The specificity of the cultural sector, expressed in the pursuit of the cooperation of } \\
\text { many theaters, museums, and other indigenous areas of culture means that there is a } \\
\text { need to modify the assumptions of the concept of strategic marketing by substituting the } \\
\text { category of competitive struggle with the category of cooperation or cooptation }\end{array}$ \\
\hline
\end{tabular}


Concept of relationship marketing

- Entities in the cultural sector operate within a network of relationships created with current and future artists as well as other employees, participants in culture, donors, the media, city, regional or national authorities, different types of schools and volunteers

- Due to the role of culture and cultural participation, both from the perspective of the individual as well as social groups, there is a need to treat participation in culture not as an incidental act, but an important element of lifestyle

- Many artists feel the need to create and deepen relationships with consumers of culture, who become their fans

- The development of the cultural sector is inherently associated with raising the quality of the offer as a category, which is one of the foundations of relationship marketing

- In the context of the risks associated with low levels of participation in culture, it is necessary to adapt the concept of the principles of relationship marketing to the specificity of the cultural sector, which stems from the fact that, along with the need to deepen relationships with loyal participants in culture, acquiring new customers who have not yet participated in culture continues to be of crucial importance

Concept of - Services provided by cultural entities are referred to in terms of services and possess the marketing of services typical features such as: intangibility, impermanence, heterogeneity, inseparability of the process of their creation and consumption, and the inseparability of the services from the person providing them

- Extending the "4 Ps" by another three elements: people, performance, and proof are relevant for the cultural sector as well

- The cultural sector is subject to servitization, and the expression of this is the introduction of different types of services, not only by institutions providing services, but also by the cultural industries and entities engaged in the production of cultural goods

Concept of territorial marketing

- Urban and regional development is not possible without their cultural functions

- Goods and services created by entities in the cultural sector are a sub-product of the territorial product

- Development of the offer created by cultural institutions is important from the point of view of the needs of residents, tourists, and investors, which are important target groups - consumers of activities in the field of territorial marketing

- The importance of communication through culture is growing from the perspective of the processes of creating a brand for a location or an image of a region

\begin{tabular}{|c|c|}
\hline $\begin{array}{l}\text { Concept of } \\
\text { value } \\
\text { marketing }\end{array}$ & $\begin{array}{l}\text { - Marketing assets including, for example, the brand and customer loyalty resulting from } \\
\text { the relationship, are key categories not only for business and cultural industries, but also } \\
\text { for cultural institutions which are non-profit organizations } \\
\text { Private entities are also found in the cultural sector and for them the purpose of } \\
\text { marketing is to provide value for their owners }\end{array}$ \\
\hline $\begin{array}{l}\text { Concept of } \\
\text { experience } \\
\text { marketing }\end{array}$ & $\begin{array}{l}\text { - Sensations and experiences are included in the processes of the creation and reception } \\
\text { of art } \\
\text { Application of the principles of the concept of experience marketing increases the value } \\
\text { and the attractiveness of the offer created by entities in the cultural sector for its } \\
\text { customers and makes it possible to have an impact on many different senses during } \\
\text { various contacts between the consumers and the cultural institution } \\
\text { - Implementation of the concept of experience marketing in the cultural sector means that } \\
\text { the symbolic capital gained by the consumer is increased } \\
\text { - Implementation of the concept of experience marketing enables the aestheticization of } \\
\text { actions taken at the stage of communicating and delivering value } \\
\text { - Transfer of the assumptions of the concept of experience marketing to the area of art } \\
\text { without taking into account its specificity may cause excessive development of culture } \\
\text { based on events }\end{array}$ \\
\hline
\end{tabular}

Source Sobocińska (2015: 91-92) 
According to the classical concept of marketing, a product, such as a theatrical performance, a symphonic concert, or a film festival should be created with the viewers or listeners in mind who we want to persuade to purchase tickets. It cannot, however, lead to the displacement of a repertoire of innovative works, or valuable but less popular ones, among the audience (Kolb 2005, Colbert 2014). There is thus a mismatch between meeting the needs of current customers and the fulfillment of the mission of specific cultural institutions. It even seems that there is an internal conflict between the classical concept of marketing and the whole ethos of artistic activity. The question of whether cultural institutions should begin with conducting a thorough examination of the possible expectations of their audiences, and then intertwine their program into a mosaic of all kinds of desirable forms of art, regardless of the level of demand which can be expected. Mokwa, Piere and Dawson (1980: 6) profess the first view: "Most can deny it, but art has been living for too long in the world of faith, hope and charity and it is getting stuck in it. Faith - that art represents a value. Hope - that someone will recognize these values and will come to examine them. Charity - that someone will pay for it, or cover the deficit. Faith is right and should be protected, but hope is blind by nature, and charity does not appear when it is needed." Searles (1980: 69), in turn, opted for the second view: "If the audience had to decide, our art world would become increasingly tighter and more sterile. Viewers have to be attracted, encouraged, or even forced towards new artistic experiences. This aspect of life the content and character of the American art world - is just too serious to be entrusted to non-artists." There is therefore a need to reconcile these two extreme views and find a balance between the preferences of the audience on the one hand and the needs of the artists on the other. The real contribution of marketing (selected concepts of marketing) in the cultural sector may be to facilitate this process. Cultural institutions often have to sacrifice short-term customer satisfaction for the long-term benefits that they can offer to the public. The role of marketing in this context thus becomes to "satisfy social needs with sensitivity".

The adoption of a particular concept of marketing and focusing on customer needs does not always mean "giving" the customers the products which are currently expected, but also understanding customer needs and wishes in the foreseeable future and finding ways to more effectively carry out the objectives of the organization, both in the short and long term. 
Products in the cultural sector are not always created the same way as other products, made in order to be placed on the market and to meet the needs of the consumer. For example, a work of art, like the entire creative effort, becomes the object of exchange under specific conditions, that is, when the market demand is created to provide such a specific product. In other cases, a work of art is created without the condition that it will become the subject of a sale. Goods and services in the field of culture and its industries are often goods of a higher order, therefore appropriate dissemination activities appear necessary. A marketing approach, fully equipped with the right instruments, may just be a competent method for integrated dissemination. This approach is evolving, with the appearance of new areas and elements alongside it, to where we might witness its positive impact on the development of the cultural sector and consequently on socio-economic development.

\section{The concept and objectives of marketing in culture}

The concept of marketing as a rational reaction of commercial and non-commercial entities to changes in the market has already reached maturity. Initially, marketing referred to the sphere of the production of consumer goods (1950s), and then to the sphere of the production of industrial goods (1960s). Over time, we began to consider the possibility of using marketing concepts in relation to non-profit organizations (1970s). Currently, the use of the classical concept of marketing in the non-profit sector is not unusual, and the status of marketing in comparison to its position at the beginning of the 70 s is incomparably higher. It has been accepted that it can be very useful in various types of organizations, including in cultural institutions. Unfortunately, when compared to other categories of non-profit organizations, not to mention commercial enterprises, these institutions very often refuse to recognize the usefulness of the concept of marketing, as witnessed by the fact that in some circles related to art, only a few years ago it was embarrassing to even mention the word "marketing".

The issue of marketing in culture first appeared in source literature in 1967. Kotler determined that cultural institutions such as concert halls, museums, opera houses, libraries, 
and universities provide specific goods, which are very popular among customers. In view of this fact, these entities have started competing for customers. Marketing activities may turn out to be very useful in this struggle, and the classical concept of marketing, after certain modifications, can also be applied in the cultural sector (Kotler 1967: 628).

Thirteen years later, the first scientific work devoted entirely to the issues of marketing in culture was published, Marketing the Arts edited by Mokwa (1980). A study by Melillo Market the Arts appeared a few years later (1983), as well as the Guide to Arts Marketing by Diggles (1986). These works largely dealt with the topic of management in culture, but proposed some important definitions of marketing in culture.

Diggles (1986: 243) writes that "the main goal of marketing in culture is to obtain an adequate number of customers for the product, i.e. the artist's creation, which in turn will result in achieving better financial results." Diggles' definition puts the artist and his product at the center of marketing. The main emphasis was placed on ensuring contact between the artist and his art, and the consumer. Diggles notes that in contrast to the commercial sector (including cultural industries), which creates a product in line with the expectations of the customer, in the case of public cultural institutions, the product is first created by the artist, and only then appropriate customers are sought. The aim of marketing in culture is therefore not meeting the specific predefined needs of a customer, but to reach an audience which will appreciate the artist's work. In the opinion of Diggles, the ultimate goal of marketing in culture is artistic rather than financial in character. Such an approach seems appropriate for a number of cultural institutions, however it does not have a wide application in the case of cultural industries that cannot count on support from the state budget or on local support, and their activities must be conducted on the basis of an economic calculation.

The definition developed by Mokwa (1980: 286) goes in the same direction: "The role of marketing is not telling the artist how to create art, the role of marketing is rather to ensure contact between the artist and the relevant audience." Thus, marketing in this sense is concerned with facilitating the exchange of services between a cultural entity and consumers so that certain social needs can be met. Therefore, the aim of marketing is to get to know the clients and recognize their desires in order to be able to meet them by creating a suitable offer. It should be added that these needs should be met in such a way as to ensure the 
development of the cultural entity, and consequently lead to the improvement of its financial results. Hence, a very important marketing objective is to develop sales, which in the case of cultural activities is often neglected. Sobocińska (2015: 102) notes that the role of marketing in the cultural sector should take into consideration artistic assumptions and economic objectives. According to Sobocińska, there are four variants related to the achievement of artistic and economic goals by entities in the cultural sector (Figure 2.1).

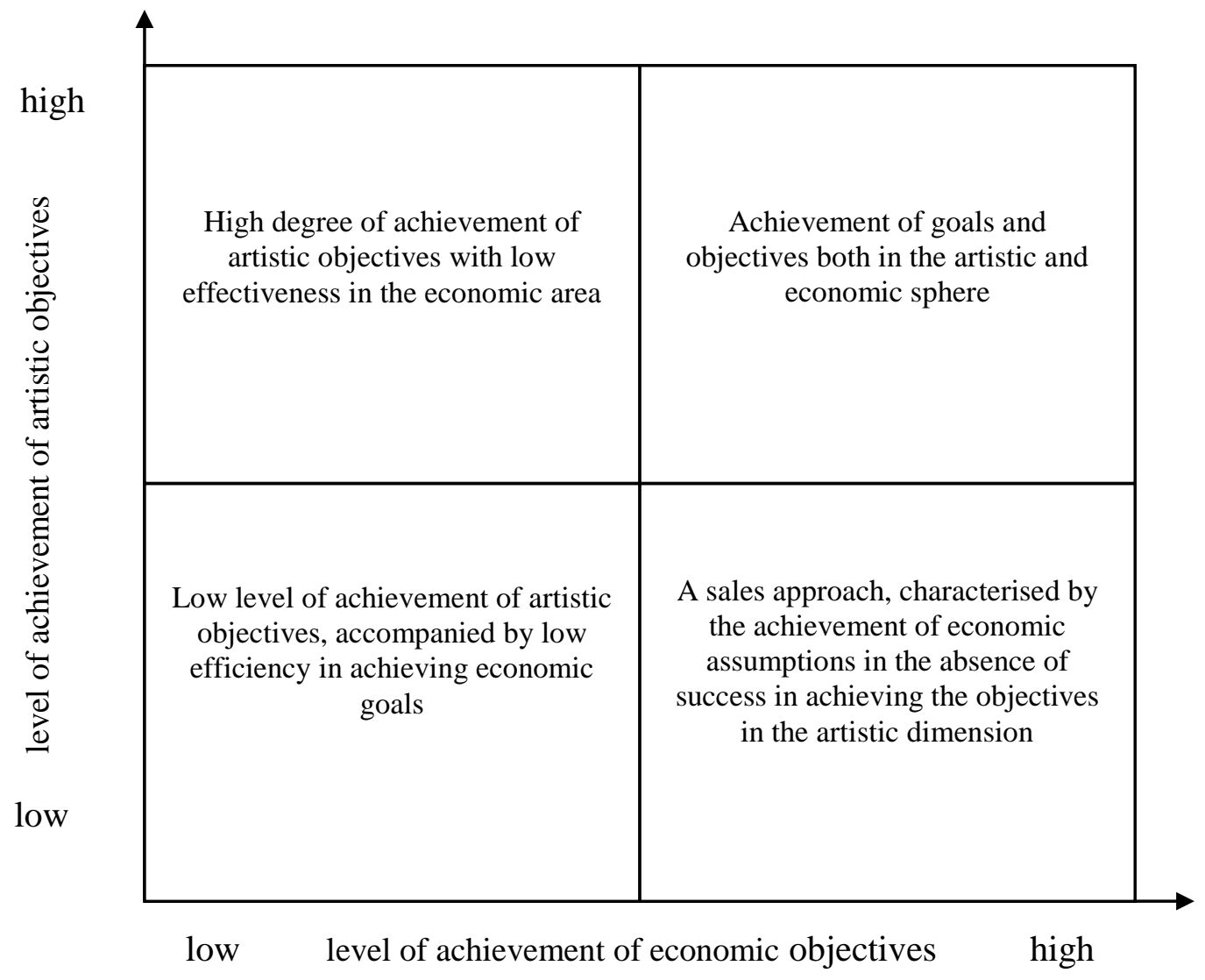

Figure 2.1 Achievement of artistic and economic objectives in the cultural sector - potential variants. Source Sobocińska (2015: 102)

Of course, in the case of entities in the cultural sector, the most desirable option is the one in which the achievement of artistic objectives is accompanied by the achievement of objectives in the economic dimension. We must remember, however, that in relation to the core artistic activity (artists, authors) or other core artistic activity (public cultural institutions), the economic objective cannot be based on the maximization of profits, but in this case it is more important for the institutions to achieve the assumed income allowing for 
their continued operation and fulfillment of their mission. In view of this, the role of marketing is to contribute to the achievement of economic objectives, which, in turn, allows for the subsequent achievement of artistic objectives. Therefore, marketing in the cultural sector is sometimes seen as work on the image, promotion, and dissemination which will attract the audience. The focus, however, must be on sales and income from sales. The purpose of such marketing is to get people to buy, to buy more, more often, now (Dragicevic-Šešić and Stojković 2010: 156). The aim of marketing activities in the cultural sector should be, in particular:

- Research into the culture market to assess the situation on the basis of which the economic policy, the nature of cultural entities, and the offer can be defined, i.e. the market structure of the programs and products of cultural institutions and cultural industries;

- Broadening cultural audiences (customers, potential audience), the promotion of specific institutions, projects, or artistic works, and the provision of relevant, factual information about programs (authors, performers, works, etc.) through various cultural management projects. These activities are aimed at arousing the interest of potential customers, so that in the future they will become regular consumers of the offer of cultural entities;

- Achievement of the highest possible income, which, in the case of public cultural institutions, will reduce dependence on financing institutions;

- Building long-term relationships with donors, volunteers, artists, and other stakeholder groups;

- Increasing the sense of autonomy at work, such that its results will become more visible both inside the organization as well as to a wide range of consumers; authority will also increase and the external and internal image of the entity will improve;

- Independence and increasing income will contribute to the growth of self-awareness of the organization's employees, strengthening incentives to work. All these factors are very important elements of human resource management that influence the effectiveness and efficiency of the work of cultural institutions, businesses, and cultural industries as a whole. 
With regard to marketing in the theater, Melillo (1983: 287) wrote: "Plays which are put on, above all, for their artistic nature, require modified marketing principles before they are included in the creative process. Only then is it possible to gain an audience for a particular event." The definitions quoted, both from Mokwa and Melillo, highlight the following issue: "Marketing has to be adapted to the needs of cultural entities, especially in relation to the specific product of public cultural institutions. The artist imposes his vision of the product on the audience, not vice versa." (Colbert 2012)

At the same time, it should be noted that marketing in the cultural sector should be treated as a set of principles and processes used when offering services in the field of culture and/or when using culture in marketing activities by enterprises treating it as an information carrier. Marketing in culture is therefore considered on two levels. These are:

- Marketing of culture - i.e. conducting the activities of manufacturing and selling products or services in the field of culture by applying the principles of marketing. This applies to cultural institutions such as cultural centers, cinemas, theaters, museums, concert halls, libraries, etc.;

- Marketing "using" culture - means the use by any company of, for example, the image of a cultural institution in the strategy of communicating with their clients. Volvo, as a company which builds its image based on the elements of durability, safety, and ecology, has been sponsoring the Gothenberg Philharmonic Orchestra since 1979. It is accepted that there is no contradiction in this, since the orchestra hall adheres to the highest values, like Volvo (Grzegorczyk 2003: 66). This part of marketing in culture is usually referred to as cultural sponsorship.

\section{Typical objections to marketing in culture}

Despite the benefits which cultural entities can draw from marketing, numerous objections have been made for years, even questioning the possibility of using marketing in the cultural 
sector (particularly with respect to the core and other core artistic activity). Arts organizations often do not recognize or are opposed to the use of marketing tools, and their decision-makers believe that the product of an artist or a cultural institution should not require any commercial approach. Hence they make many erroneous assumptions which oppose the marketing approach to culture. The most common objections which conservative decision-makers in cultural institutions have to marketing are:

- We have a good product, which is why we do not have to make marketing efforts. Assuming the expendability of marketing stems from the belief that a cultural institution conducts a valuable activity and simply deserves support per se. Cultural institutions often do not feel the need to promote their services, expecting that customers who wish to participate in a particular project will independently check the quality of activities and be attracted to them. This idea, however, is outdated. These days, customers of cultural entities have a much wider choice of leisure activities than they had even a decade ago, so they can pick among many offers;

- We know our audience, so there is no need to define the market in which we operate. All people belong to our market. Research conducted by the author in Polish concert halls shows that a considerable number of culture managers recognize that the consumers of the cultural institutions' offer should be the whole of society, and the target group of the institutions' offer should be everyone (Wróblewski 2012, 2016);

- Aggressive marketing methods should not be used when promoting culture - we have to be humble and avoid bragging. As explained by Diggles (1984: 18), the religious school of thought considers art to be sacred, with God as the audience, and that all attempts to influence its range are a profanation;

- Marketing is immoral and true cultural values will always be appreciated in the end. The allegation of immorality stems from a fundamental misunderstanding of the concept of marketing. It is often formulated this way, since marketing is seen as manipulating customers in order to convince them to buy products they do not really need. The source of this objection lies in the misunderstanding of the difference between marketing and sales (Sargeant 2004: 41). 
Despite all the objections, it seems that cultural institutions should strive to implement marketing principles. Despite their different character, these institutions have many common traits with economic enterprises and businesses in cultural industries. If the potential audience does not turn up, because it selects more attractive and perhaps also less expensive forms of leisure activities, the cultural institution will sooner or later face the dilemma of "to be or not to be". Therefore, being aware of this state of affairs, theaters, museums, concert halls, opera houses, and other cultural institutions, despite having many objections to marketing, more and more often choose to focus their activities on the customer and on the market.

\section{Model of the marketing concept in the cultural sector}

The adoption of marketing principles by cultural institutions and companies in the cultural industries does not mean that we can apply the same marketing concept to them. The specificity of the products offered by cultural institutions often leads to a situation in which the focus on the product takes precedence over the focus on the market. It seems that in the case of institutions creating works of art (core artistic activities) this is the proper focus (otherwise we are not dealing with art, but rather with entertainment). However, the situation looks different with regard to institutions which disseminate works of art (other core artistic activities), where the subjects of exchange are largely undisputed works of art. Here, without harming the artistic work itself, consumers may participate in the development of the offer intended for them, or, finally, with regard to cultural industries which are not non-profit organizations, their activities are purely commercial. Market conditions for the development of the concept of marketing in the cultural sector are presented in Figure 2.2. 


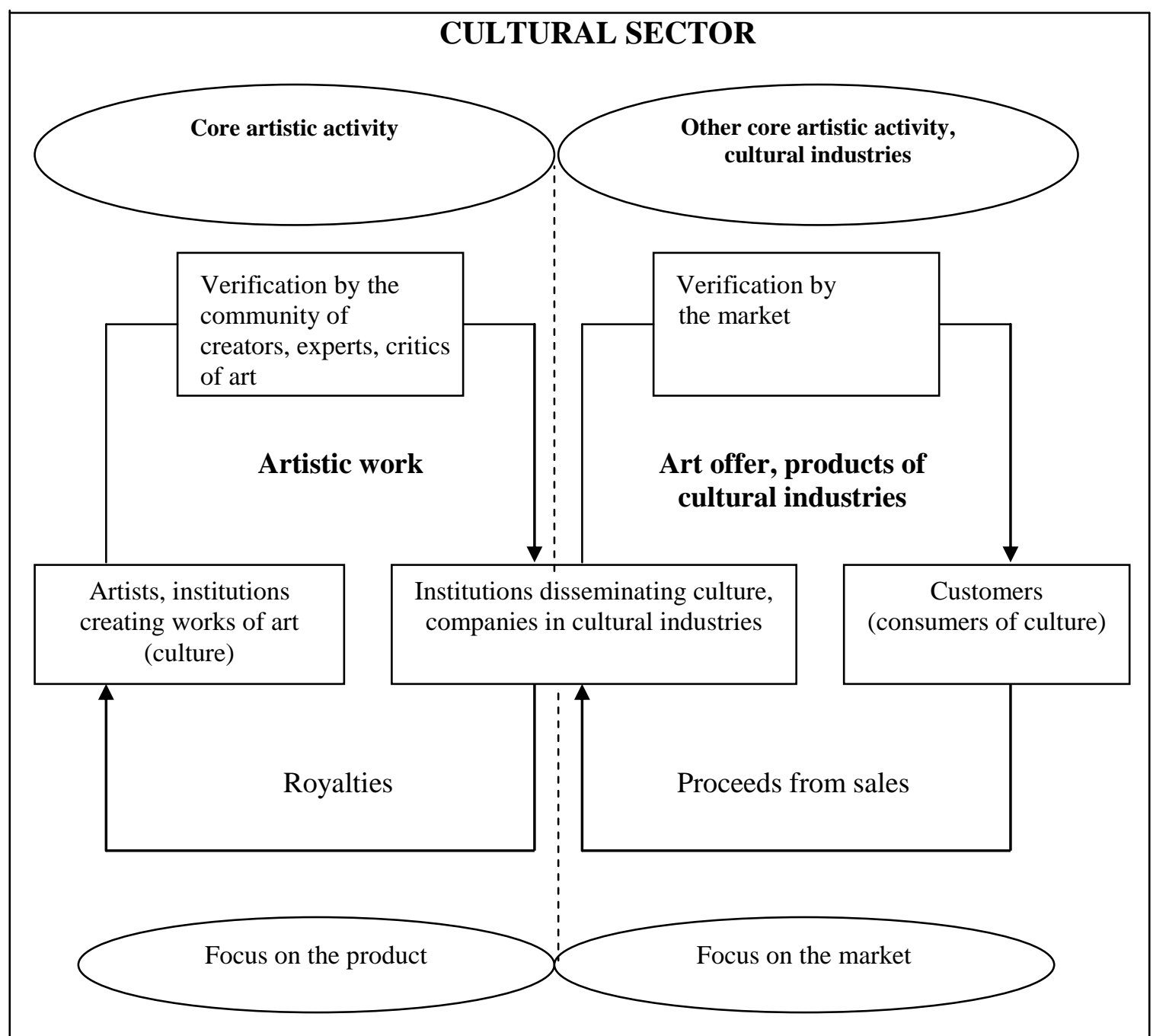

Figure 2.2 Market conditions for the development of the concept of marketing in the cultural sector

As shown in Figure 2.2, in the cultural sector, the widely understood creators of art institutions creating works of art (culture), as well as individual creators, are located on the supply side (core artistic activity). The creators produce works of art, which are then subjected to verification by the community of critics, art experts, and other artists. When the verification is successful, according to the institutional definition of art by Dickie and Danto $^{1}$, the work of art is given the status of a candidate for artistic evaluation, which is

\footnotetext{
${ }^{1}$ According to the institutional definition of art, a work of art in terms of classification is an artefact (physical object, artificially made) which constitutes a set of aspects (connotationally assigned current of meanings), which was given the status of a candidate for artistic evaluation by a person, or persons acting on behalf of the art world (renowned critic, artist, gallery director, etc.). The candidate is then subject to final verification by the audience.
} 
carried out, via the institution disseminating culture, by customers - consumers of culture. If the offer put forward by artists, cultural institutions, and cultural industries is appreciated by its audience, then it reaches the general public. In return for the artistic offer, the audience gives money to the institutions disseminating culture, which is transferred to the creators.

It should be noted, however, that this procedure applies mainly to new works placed on the market and is mostly related to the visual arts, media arts, and some literature. The performance arts which are dealt with in the cultural sector, such as musical and literary works, have often been considered unquestionable masterpieces for many years and are no longer subject to verification by the community of creators, experts, or art critics. Their authors - mostly well-known figures from the past - for obvious reasons no longer claim the rights to royalties. Customers and consumers of culture, when choosing a particular event taking place in a cultural institution (orchestra concert, opera, museum exhibition), are guided by their own preferences, so in order to discover these preferences it seems important for institutions disseminating culture and cultural industries to adopt a marketing strategy focusing on the market, and not as is the case with core artistic activity, focusing on the product.

At the same time, Levitt (1960: 50) drew attention to the fact that the concepts of sales and marketing should be clearly distinguished in the cultural sector. According to him, sales focus on the needs of the seller, while marketing focuses on the needs of the buyer. Sales are concerned with the seller's need to replace the products with cash, marketing by the idea of meeting customer needs using the product and the steps in the process associated with creating, delivering, and finally consuming it. The marketing concept is focused from the outside in. Here, the starting point is a well-defined market. The concept of sales is focused from the inside out. In this case, we start from the cultural institution (creator) and focus on existing artistic activity (Kotler 1994: 17-18). The relationship between the method of focusing on the product/market and the type of entity within the cultural sector is presented in Figure 2.3. The adaptation of theoretical models of the marketing concept in cultural institutions and cultural industries is presented in Figures 2.4 and 2.5. 


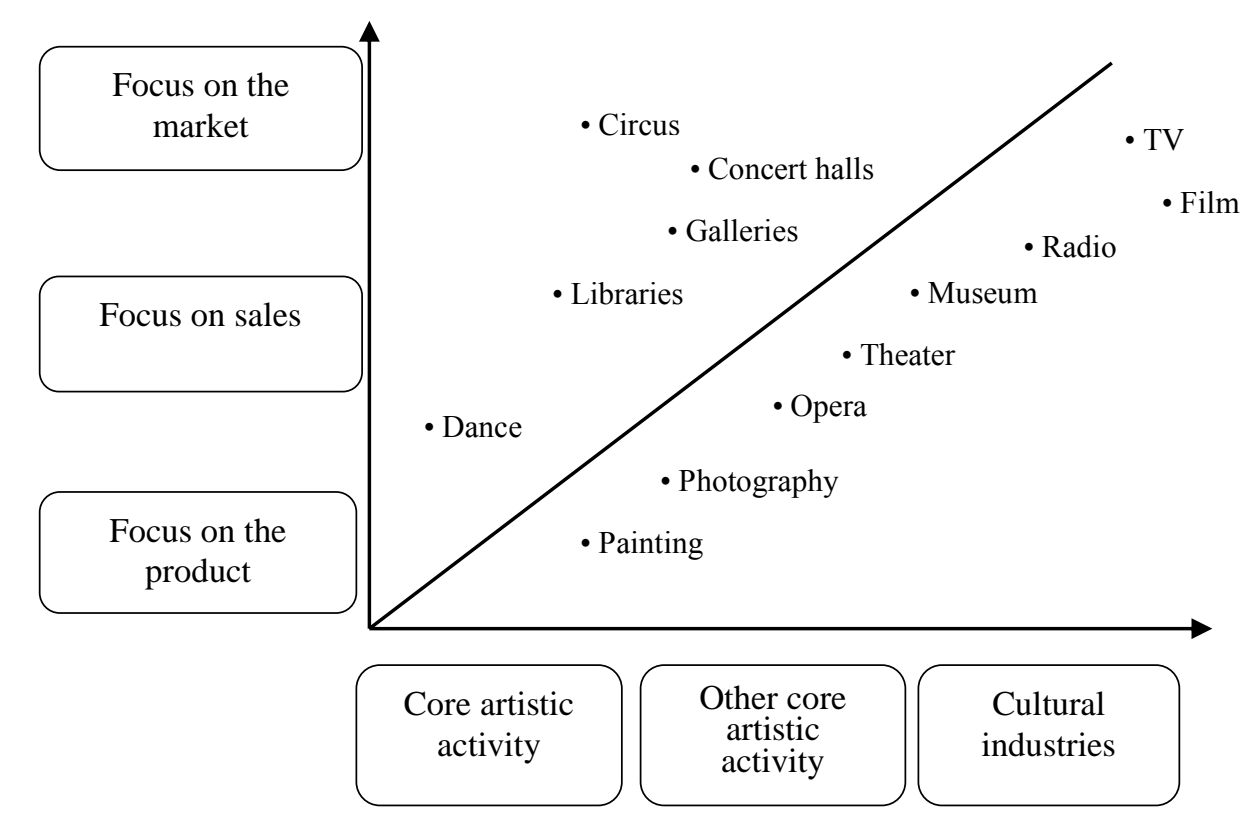

Figure 2.3 Relationship between the method of focusing on the product/market and the type of entity in the cultural sector

In the case of institutional creators (core artistic activities), as well as some institutions disseminating culture (other core artistic activity - avant-garde theaters, contemporary art museums, etc.), we are dealing with focus on the product, in which the starting point is the product or artistic creation (Figure 2.4).

The product is subject to verification by the market (is subject to evaluation by the audience of cultural institutions), but before that (according to the institutional definition of art according to Dickie and Danto), it meets with the opinion of the community of artists, critics, and art experts. These opinions provide authors with valuable information, which may or may not affect the final shape of the product offered to customers. Information is collected in the information system belonging to a cultural company, which is a coordinated team of people, activities, and tools, which aims to produce, store, and use the data provided by marketing research (Żurawik 1996: 83). 
Cultural entity

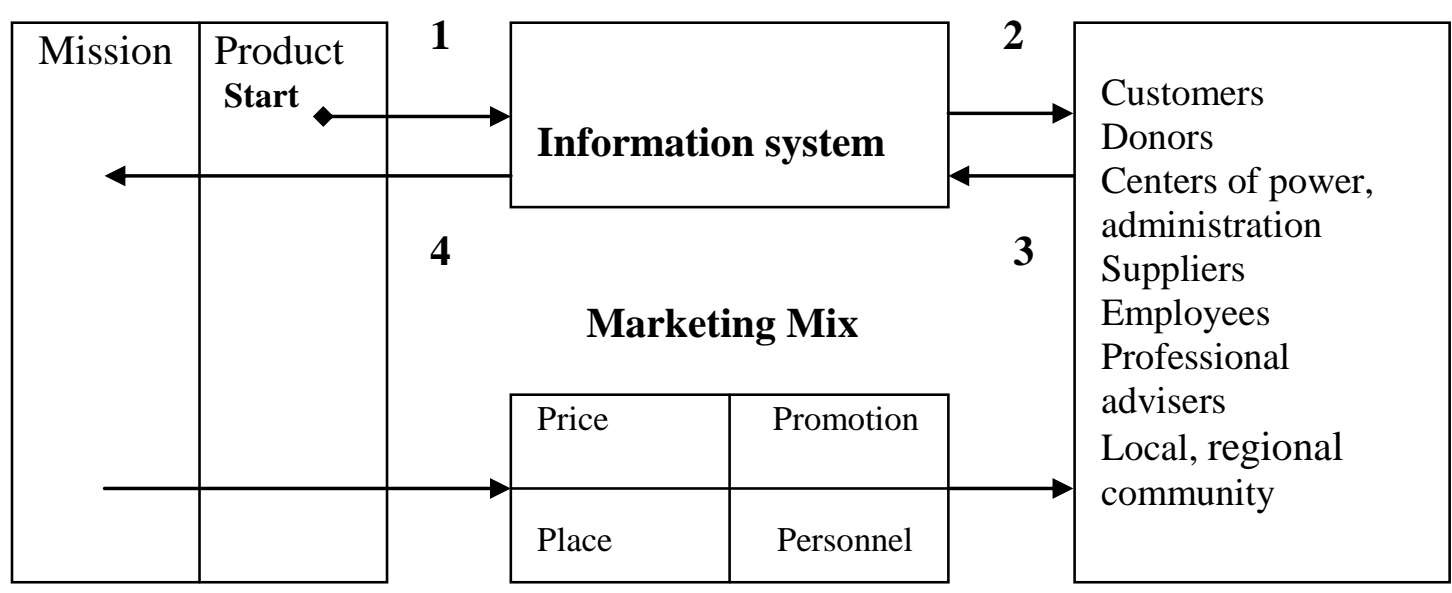

Figure 2.4 Marketing model in cultural entities focused on the product. Source Colbert et al. (1994: 22)

The system includes the following elements: information sources, a database (the place where data is collected in raw form), an interactive decision support subsystem, an interpretation and decision-making subsystem, and a results subsystem (Prymon 2001: 9). After the introduction of the product, the market sends feedback, which reaches the information system and provides the cultural entity with further valuable data on the groups of customers most interested in the new product (consumers of the artistic offer, and possibly donors). Based on the information obtained, which is analyzed and reviewed in conjunction with the mission of the institution, the cultural institution makes decisions regarding the selection of the target audience for the product. It then develops (in accordance with the segmentation previously carried out) appropriate activities in the field of the marketing mix (strategy tools) for the product, which once again reaches the market.

In regard to other core artistic activities and companies in cultural industries, it seems appropriate to focus on the market and apply the typical marketing model (Figure 2.5). 
Cultural entity

Market

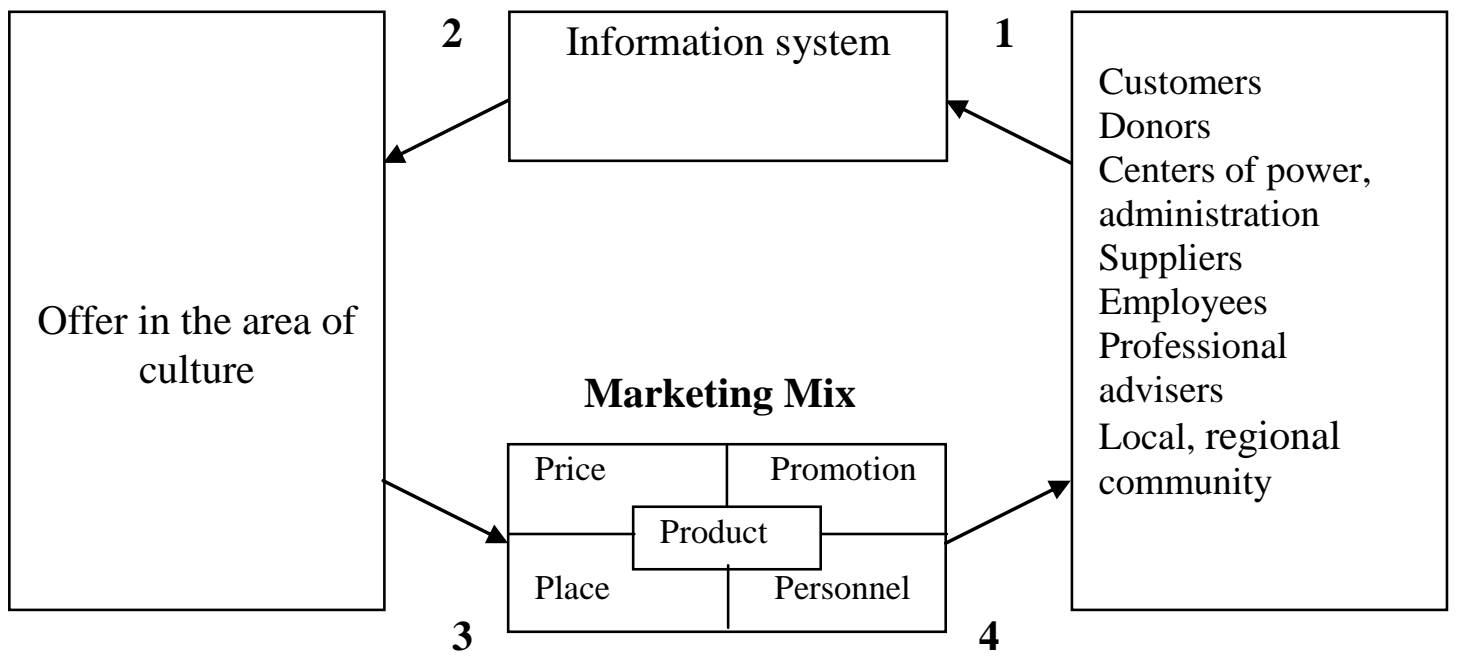

Figure 2.5 Marketing model in cultural entities focused on the market. Source Colbert et al. (1994: 15)

The starting point for cultural institutions and companies in cultural industries in this model is not the product, but the market - the customers' needs. Organizations, based on previous market research, obtain information about, for example, the preferences of consumers concerning the offer, their expectations in terms of price, distribution methods, the type of information about the product which the consumer expects, or the staff. This information is stored in the marketing information system, where it is subject to an analysis, as a result of which the organization receives valuable knowledge necessary for further action. Following the information received, market segmentation is carried out. Then, guided by the expectations and needs of the customer, a suitable offer is prepared, as well as marketing mix activities. After developing the appropriate functional strategies, the product is placed on the market.

The use of a market-focused marketing model has full justification for businesses in cultural industries; however, it must be remembered that in the case of cultural institutions, the impact of market conditions when creating a cultural offer often leads to the inclusion of 
performances, concerts, and festivals which are more commercial - closer to entertainment, i.e. cabaret, comedy, musicals, and film music. These art forms are preferred by the general public and are essential for the improvement of the financial condition of an institution. Such a choice of repertoire cannot, however, be to the detriment of the general level of art. Therefore, the task of the directors of cultural entities is the pursuit of a policy of shaping the cultural offer so that the concerts, performances, exhibitions, etc. prepared for a wide audience also allow for financing the plays, concerts, and exhibitions the reception of which is more "difficult", often avant-garde and innovative. Such a policy for shaping the offer may employ marketing portfolio methods, including the McKinsey matrix, wherein the criteria for the division of products into groups is their attractiveness on the one hand, and the competitive situation (in a given field of art) on the other. Market criteria for the choice of repertoire must be supported (supplemented) by artistic criteria and only then the concerts, performances, and exhibitions which play a fundamental role in the achievement of financial income can be identified. 


\section{References}

Boorsma M., Chiaravalloti F. (2010), 'Arts marketing performance: an artistic-mission-led approach to evaluation', The Journal of Arts Management, Law and Society, Vol. 40, pp. 297-317

Colbert F. (2012), Marketing Culture and the Arts, Carmelle and R'emi-Marcoux Chair in Arts Management, Montreal

Colbert F. (2014), 'The Arts Sector: A Marketing Definition', Psychology and Marketing, Vol. 31(8), pp. 563565, doi:10.1002/mar.20717

Colbert F., St-James Y. (2014), 'Research in Arts Marketing: Evolution and Future Directions', Psychology and Marketing, Vol. 31(8), pp. 566-575, doi:10.1002/mar.20718

Diggles K. (1984), Arts Marketing, Rhinegold Publishing, London

Diggles K. (1986), Guide to Arts Marketing: The Principles and Practice of Marketing as They Apply to the Arts, Rhinegold Publishing Limited, London

Dragićević-Sesić M., Stojković B. (2010), Kultura: zarządzanie, animacja, marketing, Narodowe Centrum Kultury, Warszawa

Fillis I. (2011), 'The evolution and development of arts marketing research', Arts Marketing: An International Journal, Vol. 1(1), pp. 11-25

Grzegorczyk A.M. (2003), Sponsoring kultury, Oficyna Wydawnicza ASPRA-JR, Warszawa

Jyrama A., Ayvari A. (2010), 'Marketing contemporary visual art', Marketing Intelligence and Planning, Vol. 28(6), pp. 723-735

Kolb B.M. (2005), Marketing for Cultural Organizations: New strategies for attracting audiences to Classical Music, Dance, Museums, Theater and Opera, Thomson Learning, London

Kotler P. (1967), Marketing Management: Analysis, Planning and Control, Prentice-Hall, Englewood Cliffs

Kotler P., Scheff J. (1997), Standing room only: strategies for marketing the performing arts, Harvard Business School Press, Boston

Lehman K., Wickham M. (2014), 'Arts-Marketing and Marketing Strategy Development: Modeling The Marketing Activities of Visual Artists across Their Career', Academy of Taiwan Business Management Review, Vol. 9(2), pp. 133-141

Levitt T. (1960), Marketing Myopia, Harvard Business Review, Boston

Melillo J.V. (1983), Market the Arts, Foundation for the Extension and Development of the American Professional Theater, New York

Mokwa M.P., Prieve E.A., Dawson W.M. (eds) (1980), Marketing the Arts, Praeger Press, New York

O’Reilly D. (2011), 'Mapping the arts marketing literature', Arts Marketing: An International Journal, Vol. 1(1), pp. 26-38

Prymon M. (2001), Współczesne badania marketingowe, Redakcja Wydawnictw Katolickiego Uniwersytetu Lubelskiego, Lublin 
Rentschler R., Shilbury D. (2008), 'Academic assessment of arts management journals: a multidimensional rating survey', International Journal of Arts Management, Vol. 10(3), pp. 60-71

Sargeant A. (2004), Marketing w organizacjach nonprofit, Oficyna Ekonomiczna, Kraków

Schroeder J.E. (2005), 'The artist and the brand', European Journal of Marketing, Vol. 39(11/12), pp. 12911305

Searles P.D. (1980), 'Marketing Principles in the Arts', in Mokwa M.P., Prieve E.A., Dawson W.M. (eds)

Marketing the Arts, Praeger Press, New York

Sobocińska M. (2015), Uwarunkowania i perspektywy rozwoju orientacji rynkowej w podmiotach sfery kultury.

Wydawnictwo Uniwersytetu Ekonomicznego we Wrocławiu, Wrocław

Wróblewski Ł. (2012), Strategie marketingowe w instytucjach kultury, PWE, Warszawa

Żurawik B., Żurawik W. (1996), Zarządzanie marketingiem w przedsiębiorstwie, PWE, Warszawa

64 Logos Verlag Berlin - Academic Books for Sciences and Humanities 


\section{Chapter 3}

\section{Strategic and marketing planning in cultural institutions}

\section{The role and importance of a mission in cultural institutions}

The process of formulating marketing strategy in the cultural sector must be correlated with its public and social mission, which is of specific importance in relation to cultural institutions. According to Lambin (2001: 368), a mission presents the long-term vision of the company from the point of view of what the company intends to do and whom it wants to serve. It defines the value system of the organization and its economic and non-economic objectives. On the other hand, Obłój (2007: 389) states that the mission of a company (including cultural institutions and companies in cultural industries) gains strategic importance when it meets three requirements: it sets the direction and applies to the future, expresses dreams and challenges (which are shared by employees), and the process of its implementation is reliable. However, with regard to the cultural sector, it should be remembered that the expression "the mission of a cultural institution" is far more important than the expression "the mission of companies in cultural industries" (mostly offering material goods - CDs, DVDs, books, newspapers, etc.). The offer of cultural institutions is mostly intangible and therefore what the cultural institution is really going to offer must be determined very precisely. Generally, the entire process of developing a marketing strategy in cultural institutions is different from the procedure used in commercial enterprises including companies and organizations operating in cultural industries, because: 
- The mission and long-term objectives in cultural institutions are usually determined by their founders at the time of establishing these entities and in most cases do not change during their operation;

- The product of cultural institutions is exceptional and often even unique;

- In cultural institutions, as opposed to cultural industries, gaining a competitive advantage is of small importance; instead, these institutions focus on cooperation or cooptation;

- The main strategy of action is the result of functional strategies and occasional strategies appearing in the environment.

A well-articulated mission, in addition to being the starting point in the process of formulating the organization's strategy and ultimately its marketing strategy, is also a point of reference which allows the cultural entity to determine appropriate and clear goals. It is also very important in terms of marketing, as it shapes its image in the environment, and in terms of information, both for those inside the organization, as well as people outside of it. The purpose of defining a mission is to make it easier for the employees of cultural institutions, companies in cultural industries, the consumers of their offer, donors, and the general public to understand the reasons for their establishment, the direction of development, and the formation of positive attitudes towards its activities. The mission of cultural institutions is conditioned by five elements: history, current preferences of the management, market environment, resources, and expertise based on competences and experience (Kotler 1994: 61). In regard to companies in cultural industries, the most useful definition of a mission should take into account three components (Abell 1980: 30-35):

- The group of clients who are to be served;

- The needs of the clients which are to be met;

- The technology to be used to meet these needs.

The development of the mission is such a responsible strategic endeavor that we must be aware of certain pitfalls. It is difficult to formulate a good mission for a cultural entity because we have to reconcile three contradictions:

- A mission should be concise, yet it has a lot to express, which is difficult to reconcile; 
- A mission should have an element of a dream, and at the same time indicate the operational road toward its implementation;

- A mission must be both general and specific.

The research which was conducted in the entities operating in the cultural sector of the Euroregion Śląsk Cieszyński in 2014, 2015, and 2016 (Wróblewski 2016) indicates that the difficulties faced by managers of entities in the cultural sector in defining the mission of cultural institutions or institutions in cultural industries mostly relate to the lack of understanding of the differences between a vision and a mission. Managers of these institutions often forget that a vision is an image of the future that the participants in the organization want to create. A mission, on the other hand, is a precise expression - in a language understood by employees and the organization's environment - of the far-reaching goals and aspirations of the organization. A mission is therefore the formulation of the vision of the company or institution for the purposes of its strategy. Difficulties also arise from a lack of faith in the success of the organization, which determines the scale of the vision and the inability to accurately convey the essence of the activities of cultural institutions in the context of the types of social needs. Selected problems associated with the formulation of the mission of entities in the cultural sector, which have been designated on the basis of studies in-depth interviews conducted with 50 managers of entities in the cultural sector of the Euroregion Śląsk Cieszyński - are presented in Table 3.1.

Table 3.1 Difficulties associated with the formulation of the mission in entities in the cultural sector Identified by employees, managers of cultural Observed by the author during consultation, institutions, institutions in cultural industries interviews, educational workshops

- $\quad$ The desire to say everything at once, which means that they became too long and wordy

- $\quad$ Distinction between the essence of a mission

The choice of vocabulary and the use of terminology appropriate for culture management

- Some of the wording seems too trivial or obvious, but if it were simplified the missions would become blurred

- Clarifying the key messages of the mission

- Expressing thoughts in words, so as not to confuse a mission with a vision

- Differentiation between a vision and a mission not in theory, but at the stage of its preparation

- Confusing the mission with the statutory objectives of the organization and a vision

- Not perceiving the sense in formulating these two elements

- Failure to take into account the social effects of cultural activities in the mission

- Depreciation of the entertainment values of cultural services

- Lack of visionary imagination in the formulation of visions: too much caution or a lack of faith in the possibility of implementing a "grander" vision

- Inability to group the activities of an institution according to the criterion of the social needs to be satisfied by the services provided and the cultural products 
In the analysis of the missions of Polish operas and concert halls (Table 3.2) we can see that they are defined very conservatively; it is difficult to see future plans or dreams in them. This was also confirmed by research which was carried out among a group of 50 managers of cultural institutions and institutions in cultural industries during the "Educational Workshop for Managers of Cultural Institutions", which was conducted by the author in Poland (Cieszyn) and Czech Republic (Český Těšín) in 2014, 2015, and 2016. The managers, when asked to imagine their organizations 15 years from now, mostly responded with the hope that they would manage to survive in an increasingly competitive market. Examining the missions of Polish operas and concert hall more closely, we can also say that the concept of the mission of ten of them stems directly from the main idea of marketing, according to which companies achieve long-term success if their goals are subordinated to satisfying the needs of consumers. The missions of these institutions contain a statement saying that the goal of the opera or concert hall is to meet the needs and musical aspirations of the public. A list of the missions of all opera houses and concert halls in Poland is included in Table 3.2 .

Table 3.2 Missions of Polish opera houses and concert halls

\begin{tabular}{|c|c|c|}
\hline $\begin{array}{c}\text { No } \\
.\end{array}$ & $\begin{array}{c}\text { Cultural } \\
\text { institution }\end{array}$ & Mission included in the statutes of the organization \\
\hline 1 & $\begin{array}{l}\text { Grand Theater - } \\
\text { National Opera } \\
\text { in Warsaw }\end{array}$ & $\begin{array}{l}\text { Preparation and display of operas, ballets, and musical pieces from the national and } \\
\text { international repertoire. }\end{array}$ \\
\hline 2 & Krakow Opera & $\begin{array}{l}\text { Co-creation and dissemination of the achievements of the Polish national opera and } \\
\text { international operas, operettas, ballets, musicals, and other cultural activities. }\end{array}$ \\
\hline 3 & $\begin{array}{l}\text { Baltic Opera in } \\
\text { Gdansk }\end{array}$ & $\begin{array}{l}\text { Meeting the cultural needs of the public through artistic activities in the field of } \\
\text { opera, ballet, and other musical forms, as well as educational activities promoting } \\
\text { the opera and ballet. }\end{array}$ \\
\hline 4 & Wroclaw Opera & $\begin{array}{l}\text { Promoting culture, music, and theater by organizing opera, ballet, theatrical } \\
\text { performances, and concerts. }\end{array}$ \\
\hline 5 & $\begin{array}{l}\text { Grand Theater in } \\
\text { Łódź }\end{array}$ & $\begin{array}{l}\text { Conducting artistic activity in the field of opera, ballet, and other forms of music, } \\
\text { with the participation of artists and performers who hold appropriate professional } \\
\text { qualifications, in order to meet the cultural needs of the public and the development } \\
\text { of culture and art in Łódź, in the Łódź Province and throughout the country, as well } \\
\text { as representing Polish culture abroad. }\end{array}$ \\
\hline
\end{tabular}


\begin{tabular}{ll}
\hline & Warsaw \\
& Chamber Opera
\end{tabular}

7 Opera Nova in

Bydgoszcz

8 Podlasie Opera and Philharmonic

- European Art

Centre in

Białystok

9 Opera na Zamku in Szczecin

13 Częstochowa Philharmonic

14 Lower Silesian Philharmonic in Jelenia Góra

15 Olsztyn Philharmonic

16 Szczecin Philharmonic

17 Wrocław Philharmonic

18 Kalisz Philharmonic

19 Lublin Philharmonic
Shaping and promoting music and theater by organizing opera performances and concerts with professional soloists, vocal groups, instrumental groups, ballet groups, and acting groups.

Promoting music, theater, and ballet.

Development and dissemination of culture and music education.

Preparation and staging of operas, ballets, musicals, the promotion of Polish and international achievements in opera, operetta, ballet, musicals, and other forms of cultural activity, with the participation of in-house groups and artists, as well as with the help of groups and artists which are invited from the national and international arena.

Co-creation and dissemination of musical culture through the preparation and staging of operas and ballets with the participation of professional performers.

Promoting culture and creating performances in the field of musical theater, opera, and ballet both in Poland and abroad.

Cultivating and developing the tradition of Polish music, depicting the wealth of world musical heritage, promoting contemporary music, and the dissemination of musical culture both in Poland and abroad. Aiming to achieve the highest level of artistic activity and attentiveness to the representative nature of music programs.

Presentation of valuable forms of classical music, jazz, and popular music from Poland and abroad, as well as musical education which prepares children and youth for the conscious reception of music in all its genres.

Dissemination of music, and meeting the needs and musical aspirations of the public as well as the representation of Polish culture both in Poland and abroad.

Conducting artistic activities with the participation of artists and performers with professional qualification in the field of music in order to meet the cultural needs of the inhabitants of the Warmian-Masurian Province.

Activity in the sphere of artistic culture through the implementation of music concerts, their presentation, and the carrying out of projects which accompany them with the use of an in-house band.

Dissemination of music, the development of musical culture, and the meeting of the needs and musical aspirations of the public, as well as the representation of Polish culture both in Poland and abroad.

Dissemination and protection of culture in the field of music, as well as meeting the musical aspirations and needs of the public.

Conducting cultural activities in the field of music based on the artistic work of the symphony orchestra, chamber ensembles, individual musicians, and choirs. 
20 Krakow

Philharmonic

21 Koszalin Philharmonic

22 Łódź Philharmonic

23 Opole Philharmonic

24 Pomeranian Philharmonic in Bydgoszcz

25 Poznań Philharmonic

26 Sudety Philharmonic in Wałbrzych

27 Silesian Philharmonic in Katowice

28 Świętokrzyska Philharmonic in Kielce

29 Zabrze Philharmonic

30 Zielona Góra Philharmonic

31 Rzeszów Philharmonic

32 Polish Baltic Frédéric Chopin Philharmonic in Gdańsk
Co-creation and dissemination of musical culture. The management of professional music groups: orchestra, choir, instrumental chamber ensembles, as well as conducting educational activities for children and adolescents.

Presentation of valuable forms of Polish and foreign symphonic music, chamber music, classical music, and contemporary music. Recognizing and meeting the needs in the field of music culture.

Conducting cultural activities with the participation of artists and performers, which hold appropriate professional qualifications, in order to meet the cultural needs of the public and for the development of culture and art in Łódź, the Łódź region, as well as in areas without access to cultural institutions. Representation of Polish culture abroad.

Conducting artistic activity with the participation of artists and performers with professional qualifications in the field of music in order to meet the cultural needs of the inhabitants of the Opole Province, and promoting music among children, youth, and adults both in Poland and abroad.

Conducting artistic activity in the field of music with the participation of artists and performers with relevant professional qualifications.

Promoting and dissemination of musical culture based on an in-house orchestra and a boys' and men's choir, as well as with the participation of guest soloists and musical ensembles.

Co-creation and dissemination of musical culture by organizing symphonic concerts, chamber music concerts and recitals, competitions and festivals, school concerts and programs, making recordings for radio, television, vinyl/CD and audiovisual recordings, representation of Polish culture both in Poland and abroad.

Co-creation and dissemination of musical culture.

Meeting the needs and cultural aspirations of the public and the creation of conditions for active participation in culture. In particular: the systematic raising of the level and shaping of the musical culture of the public, meeting the needs and preferences of customers in the field of music, the fulfillment of leading functions in the development of musical culture in the region.

Popularizing musical culture using means appropriate for this type of cultural institution.

Conducting artistic activity in the field of music with the participation of artists and performers with relevant professional qualifications.

Shaping the cognitive and aesthetic sensitivity of the public, providing opportunities for contact with the values of Polish and world culture in the field of music and related arts.

Satisfying the cultural needs of the public through artistic activities in the field of music.

70 Logos Verlag Berlin - Academic Books for Sciences and Humanities 
The mission should state what the entity in the cultural sector intends to achieve, but it must be worded in such a way that the mission can be consistently fulfilled over a longer period of time. Generally the mission should be reevaluated every five years. It should not be necessary to update it every year, since its purpose is only to set a general direction. The specific details of the results which should be achieved in individual planning periods are usually part of the strategic objectives. Specific, measurable strategic goals are essential to bring the mission to life.

\section{Strategic objectives and the main directions of development of cultural entities}

In contrast to the cultural industries, where the main client is the consumer of the offer or the purchaser of goods and services, the presence of different groups of customers in the environment of a cultural institution (e.g. consumers of the artistic offer, donors, regional community, employees) has serious implications in the formulation of its strategic objectives. Despite the fact that these groups do not have to appear in the environment of all the cultural institutions, as well as the fact that the importance of their individual types is not the same for them, positive relationships should be created with all existing groups (Limański and Drabik 2007: 185). As a result, the strategic objectives of entities in the cultural sector and in particular of public cultural institutions correspond to the heterogeneous structure of their customers and their character can be either: artistic, focused on dissemination, sociostructural, focused on the market, financial, or organizational. The directions of the strategic objectives of entities in the cultural sector with examples are shown in Table 3.3. 
Table 3.3 Strategic objectives of entities in the cultural sector

\begin{tabular}{|c|c|}
\hline Strategic objectives & Examples of directions \\
\hline Artistic & $\begin{array}{l}\text { - } \quad \text { Presenting the most valuable works of art } \\
\text { - } \quad \text { Representing the national culture both in Poland and abroad } \\
\text { - } \quad \text { Promotion of young talented artists } \\
\text { - } \quad \text { Creating conditions conducive to the development of creativity }\end{array}$ \\
\hline $\begin{array}{l}\text { Focused on } \\
\text { dissemination }\end{array}$ & $\begin{array}{l}\text { - Dissemination of works of art } \\
\text { - Promoting and dissemination of culture } \\
\text { - Cultural education and the preparation of children and youth to become } \\
\text { future customers and creators of works of art }\end{array}$ \\
\hline Sociostructural & $\begin{array}{l}\text { - } \quad \text { Ensuring the prestige of cultural entities } \\
\text { - } \quad \text { Achieving an undisputed place in history }\end{array}$ \\
\hline $\begin{array}{l}\text { Focused on the } \\
\text { market }\end{array}$ & $\begin{array}{l}\text { - Achieving a certain market share } \\
\text { - Increasing the degree of acceptance in the chosen market segment }\end{array}$ \\
\hline Financial & $\begin{array}{l}\text { - Increasing the budget revenues of the cultural entity } \\
\text { - Increasing donations from donors } \\
\text { - Increasing own revenues } \\
\text { - Increasing the value of property at the disposal of the cultural entity }\end{array}$ \\
\hline Organizational & $\begin{array}{l}\text { - Acquiring talented artists, professionals } \\
\text { - Creating new branch offices, subsidiaries of the institution, new artistic } \\
\text { groups, etc. }\end{array}$ \\
\hline
\end{tabular}

The objectives focused on dissemination in cultural institutions should be understood as the implementation of participation in culture, rather than promoting participation in culture. In the latter case, we can talk about the objectives of cultural institutions focused on the market, not on dissemination.

In addition to missions, all the operas and concert halls in Poland have also defined their strategic objectives. In the vast majority, these are artistic and dissemination objectives, such as: presentation and dissemination of the musical achievements of Polish culture and the musical works the most recognized composers of the world. Some institutions also have sociostructural objectives - making radio, television, vinyl/CD and audiovisual recordings, as well as organizational objectives - engaging eminent Polish and foreign artists. A detailed list of the strategic objectives of Polish operas and concert halls (main directions) are presented in Table 3.4 . 
Table 3.4 Strategic objectives of Polish opera houses and concert halls

\begin{tabular}{|c|c|c|}
\hline No. & $\begin{array}{l}\text { Cultural } \\
\text { institution }\end{array}$ & Main strategic objectives \\
\hline$\overline{1}$ & $\begin{array}{l}\text { Grand Theater - } \\
\text { National Opera } \\
\text { in Warsaw }\end{array}$ & 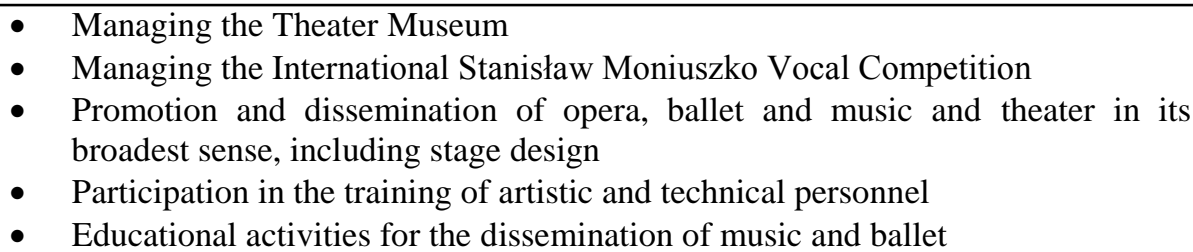 \\
\hline
\end{tabular}

2 Krakow Opera

- Managing professional groups and an opera and operetta house, a ballet studio, and a choir for children and youth

- Creating conditions for cultural education, education through art, in particular, the preparation of children and youth to become consumers and future contributors to the national culture

- Creating conditions conducive to the development of creativity and artistic talents

- Ensuring the protection of national heritage by preserving opera souvenirs and traditions

- Exchange of artistic achievements and creative thoughts with other operas and musical theaters both in Poland and abroad

- Cooperation with state and local cultural institutions, non-governmental organizations and other entities and individuals both in Poland and abroad

3 Baltic Opera in Gdansk

$4 \quad$ Wroclaw Opera
- Organizing musical, opera and ballet performances, symphony concerts, chamber music concerts, recitals, and other artistic forms with the participation of in-house groups and artists, as well as guest or temporarily hired national and international groups and artists

- Recordings of artistic productions and their dissemination for archival, promotional, and advertising purposes

- Acting as an impresario

- Organizing and supporting festivals, reviews, competitions, exhibitions, and other events

- Cooperation with the social art movement, particularly through promotion, teaching aid, material aid and the training of musically talented youth, sponsoring the participation of the consumers of culture from various social groups in events organized by the Opera

- Attentiveness to artistic development and the proper use of the professional qualifications and abilities of performers employed in the opera

- Cooperation with artist unions and associations in the field of inspiring Polish creativity in the opera, ballet and music

- Cooperation with artistic training in the preparation of artistic human resources for the opera

- Cooperation with national and foreign cultural institutions, in particular with opera theaters, through the artistic exchange of artists, groups and performers, as well as the exchange of experiences in the implementation of artistic projects

- Organizing and inviting other theaters, groups and performers in order to present performances and events worthy of dissemination

- Promotion of Polish operas, ballets and music both in Poland and abroad (in the press, radio and television, at fairs and other events 
5 Grand Theater in - Preparation and the production of opera and ballet performances in order to Łódź disseminate the most outstanding works of Polish and international opera and ballet music

- Shaping, presenting and disseminating historical and contemporary cultural heritage

- Cultural education and education through art

- Cooperation with creative communities and the socio-cultural movement

6 Warsaw Chamber Opera

- Staging Polish and foreign operatic works

- Organization of concerts, performances and meetings, also outside the seat of the opera

- $\quad$ Promotion of Polish and foreign musical works

- Running the in-house music library

- Editorial activities, publishing and educational activities popularizing musical theater culture

- Acting as an impresario in the field of domestic and foreign cultural exchanges

- Ensuring the protection of the cultural heritage of Polish and foreign music (including works of early Polish music)

- Creating conditions conducive to the development of creativity and artistic talents

7 Opera Nova in Bydgoszcz

$8 \quad$ Podlasie Opera and Philharmonic - European Art Centre in Białystok
- Organizing operas, operettas, musicals, ballet performances, concerts, musical and stage forms with the help of in-house and external professional ensembles and soloists

- Implementation of the artistic program based on the seasonal repertoire plans and impresario activities

- Organizing and performing stage forms: opera, operetta, musical, ballet, dance, theater, and concert forms: symphonic concerts, oratorios, chamber music, recitals, and other artistic events

- Cultural education and education through art, in particular the preparation of children and youth to become future consumers and creators of culture

- Creating conditions conducive to the development of creativity and artistic talents

- Maintaining contacts with artistic education and creative communities

- Establishing cooperation and the implementation of agreements with institutions, organizations, associations both in Poland and abroad, in the field of the popularization and dissemination of music both in Poland and abroad

- Initiating new forms of the dissemination of art in different social environments

- Documenting the audio and video of all artistic events and have them at the institutions disposal to use in accordance with the interests of the institution

- Dissemination of film culture by creating the conditions for universal access to the achievements of Polish and international film art

- Organization of other projects aimed at the dissemination of culture, such as seminars, conferences, courses, workshops and competitions

- Conducting advertising and promotional activities for the dissemination of culture 
9 Opera na Zamku - Creating conditions for cultural education, education through art, in particular in Szczecin the preparation of children and youth to become consumers and future contributors to the national culture

- Shaping the artistic sensitivity of young people

- Promotion and dissemination of opera, ballet and music

- Exchange of artistic achievements and creative thoughts with other operas and musical theaters both in Poland and abroad

- Cooperation with state and local cultural institutions, non-governmental organizations and other entities and individuals both in Poland and abroad

10 Silesian Opera in - Acting as an impresario in accordance with the artistic profile, making the stage Bytom available to other cultural institutions and groups for operetta, theater and stage performances, in order to broaden the repertoire

- Conducting educational activities in the field of statutory tasks

11 Grand Theater in Poznań

12 Warsaw Philharmonic

13 Częstochowa Philharmonic

14 Lower Silesian Philharmonic in Jelenia Góra
- Cooperation with social and cultural organizations in the preparation of various projects relating to the promotion and creation of musical, theater, ballet and opera culture

- Cultural education and support of amateur art movements

- Collection, documentation and sharing of materials related to the activities of the opera

- Recording and the transmission of audio-visual material on its own accord and in cooperation with other entities

- Cooperation with artistic education

- Publishing activities

- Training and teaching activity as well as acting as an impresario and manager both in Poland and abroad

- Organizing concerts with the use of in-house and external groups

- Hiring prominent Polish and foreign artists

- Conducting promotional, publishing and journalistic activities

- Conducting music promotion campaigns for children and youth, and also teaching and popularization

- Organizing symphonic concerts, oratorios and cantatas, chamber music, jazz and popular music concerts at the concert hall and externally, with the participation of in-house groups and guest artists from Poland and abroad

- $\quad$ Promotion of Polish and foreign contemporary music

- Recognizing, arousing and meeting the needs in the field of musical culture

- Organizing and co-organizing music festivals

- Development and the implementation of programs in the field of music education for children and youth

- Promotion of the city of Częstochowa through campaigns in the field of musical culture

- Promotion of local music circles, artists and performers through concerts, recordings for radio, television and vinyl/CD, as well as editorial activities

- Cooperation with music schools and social cultural movements in terms of initiating new forms of the dissemination of music in different environments

- Presentation and dissemination of the musical achievements of Polish culture, and the most valuable works of international music

- Developing, cultivating and the dissemination of national, regional and Euroregional traditions in the field of music 
- Cooperation and the exchange of experiences with other cultural institutions both in Poland and abroad

- Cooperation with non-governmental institutions in the country and abroad, especially the Association of Polish Municipalities Euro region Nysa

- Cooperation and the exchange of experiences with music schools on various levels both in Poland and abroad

- Musical education for children and youth by promoting music among children and youth

- Creating conditions conducive to the development of creativity and musical talents

- Creating conditions for the presentation of historic sites in the city and in the region by organizing various musical forms

- Artistic and scientific activity in different fields of art (music, dance, acting)

15 Olsztyn

Philharmonic

16 Szczecin

Philharmonic

17 Wrocław Philharmonic

18 Kalisz Philharmonic
- Shaping, presenting and disseminating historical and contemporary national and international cultural heritage

- Cultural education

- Presentation of Polish and international cultural heritage characterized by its high artistic level

- Musical education of children and youth

- Promotion of local music circles

- Cooperation and cultural exchanges both in Poland and abroad

- Cooperation with institutions, associations, social art movement, and individual artists for the development of musical culture

- Organization of cultural events with a local, national, and international reach

- Presentation and the dissemination of the musical achievements of Polish culture, and the most valuable works of international music

- Promotion of young musicians, creating conditions conducive to the development of creativity and musical talents

- Musical education for children and youth by promoting music among children and youth

- Cooperation with the artistic, scientific, social environment, and the cultural social movement

- Participation in domestic and foreign artistic cooperation and exchange

- Management and organization of group participation in culture

- Various forms of music education

- Individual forms of cultural activation

- Symphonic concerts, chamber music concerts and recitals

- Concerts and musical programs for children and youth

- Music-related events

- Cooperation with the social cultural movement and artistic associations

- Domestic and foreign artistic cooperation and exchange 
- Musical education, preparing children and youth for the conscious reception of music in all its genres

- Promotion of Polish and foreign contemporary music

- Promotion of musical interests and activities among consumers

- Cooperation with the social music movement for the development of musical culture

- Organizing symphonic, oratorio and cantata, chamber music and popular concerts with the participation of in-house ensembles, soloists, conductors as well as guest artists from Poland and abroad, in the concert hall and other locations

- Development and implementation of educational and music programs for children and youth

- Organizing and co-organizing concerts and music festivals in the concert hall and other locations

- Promotion of local music circles, artists and performers through concerts, recordings and editorial activities

- Keeping a sheet music archive

20 Krakow Philharmonic

21 Lublin Philharmonic

22 Łódź Philharmonic

23 Opole Philharmonic
- Management of professional groups: symphony orchestra and choir

- Organizing symphonic and chamber music concerts, recitals, festivals

- Creating conditions for cultural education, education through art, in particular preparing children and youth to become consumers and future contributors to the national culture (concerts and programs for children and youth)

- Creating conditions conducive to the development of creativity and artistic talents

- Concert activities carried out at the headquarters of the institution and externally

- Musical education for children and youth, by organizing regular programs and musical education concerts, etc.

- Promotion of early and contemporary Polish music

- Cooperation with musical circles, cultural social movements and musical institutions both in Poland and abroad

- Creating conditions for the improvement of the artistic and professional skills of employees and talented youth

- Preparation and the implementation of concerts in order to promote the most outstanding works of Polish and international music

- Shaping, presenting and disseminating historical values and contemporary national and international musical heritage

- Cultural education and bringing up children and youth as future consumers and creators of art, taking into account their cultural needs through concerts and music programs

- Cooperation with creative communities and the socio-cultural movement

- Shaping, presenting and disseminating national and international musical heritage

- Musical education and the preparation of children and youth to become future customers and creators of musical art

- Cooperation with the social cultural movement, artistic associations and local governments in undertaking joint initiatives to arouse and satisfy the needs and cultural interests

- Presenting and cultivating regional musical output, the presentation of outstanding performers and musical works associated with the region 
24 Pomeranian Philharmonic in Bydgoszcz
25 Poznań Philharmonic

26 Sudety Philharmonic in Wałbrzych

27 Silesian Philharmonic in Katowice

28 Świętokrzyska Philharmonic in Kielce
- Shaping, presenting and disseminating historical and contemporary national and international cultural heritage

- Developing, cultivating and promoting national and regional traditions and cultural heritage protection

- Cultural education and education through art and in particular the preparation of children and youth to become future creators and consumers of culture

- Creating conditions conducive to the development of creativity and artistic talents

- Organization of cultural events and campaigns with a special emphasis on musical forms

- Cooperation and cultural exchange with foreign partners, participation in the organization of international cultural events, aimed at discovering and bringing together the cultures of nations cooperating with Poland

- Publishing and information activities in the field of music education and art

- Organizing, domestically and abroad, symphonic concerts, cantata and oratorio concerts, chamber music concerts, choral concerts, vocal and instrumental recitals

- Cooperation with public organizations

- Cultural education

- Collection, documentation and the sharing of materials related to the activities of the Philharmonic concert hall

- Organizing symphonic concerts, chamber music concerts and recitals, competitions, festivals, school concerts and programs

- Making radio, television, vinyl/CD and audio-visual recordings

- Representation of Polish culture both in Poland and abroad

- Management of professional groups: symphony orchestra, chamber orchestra and a choir

- Preparing and presenting symphonic concerts, choral concerts, operas, oratorios, chamber music concerts and recitals, as well as educational concerts and school programs

- Organizing competitions and festivals, including the Grzegorz Fitelberg International Competition for Conductors

- Making radio, television and vinyl/CD recordings, creating book and audiovisual publications

- Organizing symposia, sessions and conferences in the field of musical art

- Organizing symphonic concerts, chamber music concerts and recitals, and other forms of presentation of music in the broad sense of the word

- Participation in the musical education of children and youth by organizing school concerts and music programs in schools

- Appropriate selection of program items, taking into account their real and objective artistic value as well as the historical and contemporary social function

- Promotion of Polish and foreign musical works

- Patronage of amateur musical movements, in particular the support and promotion of amateur artistic movements

- Integrating the music environment of the Świętokrzyskie Province 
29 Zabrze

Philharmonic

30 Zielona Góra Philharmonic

31 Rzeszów Philharmonic

32 Polish Baltic Frédéric Chopin Philharmonic in Gdańsk
- Preparation of repertoire items, valuable in artistic terms, responding to the different needs and interests of the public

- Inspiring musical creativity

- Bringing together the most talented musicians and soloists in the orchestra

- Cooperation with artist associations and arts organizations

- Cooperation with musical institutions both in Poland and abroad

- Establishing cooperation with cultural and educational institutions in order to pursue music education

- Cooperation with art high schools and colleges as the main source of the selection of young art staff

- Shaping, presenting and disseminating historical and contemporary national and international cultural heritage

- Developing, cultivating and promoting national and regional traditions and cultural heritage protection

- Cultural education and education through art, in particular the preparation of children and youth to become future creators and consumers of culture

- Creating conditions conducive to the development of creativity and artistic talents

- Organization of cultural events and campaigns with a special emphasis on musical forms

- Cooperation and cultural exchange with foreign partners, participation in the organization of international cultural events, aimed at discovering and bringing together the cultures of nations cooperating with Poland

- Publishing and information activities in the field of music

- Presentation of symphonic concerts and other musical forms at the Philharmonic concert hall and in other locations

- Various forms of music education aimed at preparing children and youth to become future consumers and creators of culture

- Cooperation with national and foreign institutions conducting similar activities

- Cooperation with the social cultural movement in organizing individual and group participation in culture

- Cooperation with other scientific, social and charitable organizations in activities aimed at developing the cultural community

- Making recordings in order to popularize and promote music

- Dissemination of the artistic achievements of the orchestra in the form of printing publications (brochures, newsletters, programs) and recordings using available audiovisual techniques

- Organization of orchestra tours

- Presentation and dissemination of the musical achievements of Polish culture, and the most valuable works of international music

- Various forms of music education aimed at preparing children and youth to become future consumers and creators of culture

- Cooperation with musical institutions both in Poland and abroad

The study confirms that cultural institutions in Poland do not exclude market-related and financial objectives. The representatives of the 18 surveyed concert halls strongly agreed with the statement that the strategic objective of the concert hall should be to attract new 
consumers interested in the artistic offer, and $67 \%$ of the institutions surveyed felt that the strategic objective of the concert hall should also be to increase sales. The main marketing objectives in concert halls include increasing the level of knowledge of the concert hall among current and potential listeners (100\%), shaping the image of the concert hall (89\%), keeping current customers interested in the artistic offer (83\%), increasing the level of customer satisfaction (83\%), cooperation with distinguished conductors and artists (78\%), providing information about the activities of the concert hall (72\%), extending the degree of knowledge of the repertoire (67\%), and promotion of young talented artists (55\%).

The strategic objectives of cultural institutions and companies in cultural industries stem from intentions relating to the desired position of the company or institution on the market. We can observe, however, a certain dependency: in the case of public cultural institutions artistic, dissemination-related, or sociostructural objectives come to the foreground (which results directly from the mission of these institutions), while in the case of companies in cultural industries (mostly business organizations), financial and market-related objectives seem to be key (Figure 3.1).

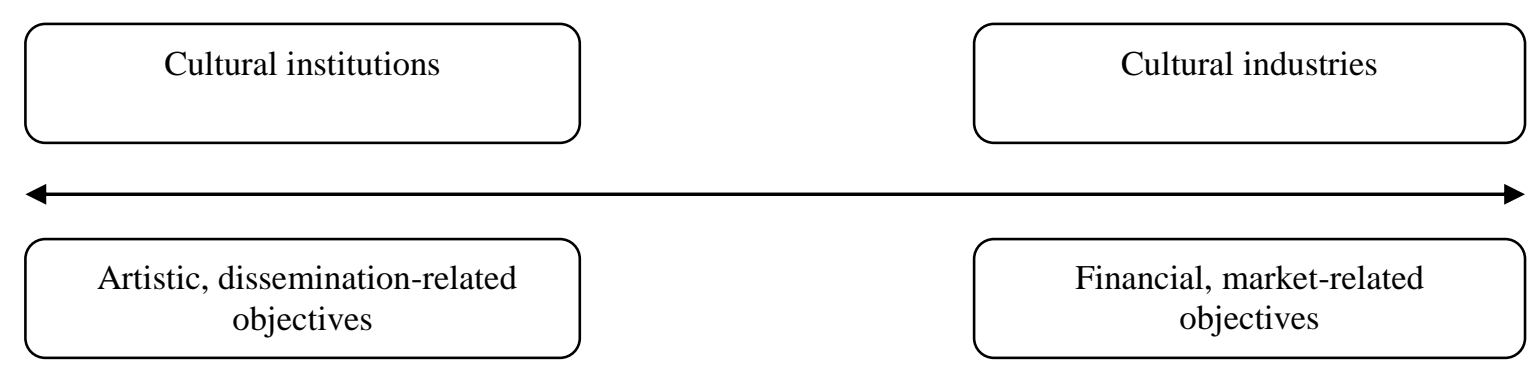

Figure 3.1 Strategic objectives of cultural institutions, companies in industries - continuum

Simon (1964) stated that the strategic objectives should be regarded as a bundle of limitations, and which of these limitations are treated as the most important at a given time, and which are the focus of cultural institutions or companies in cultural industries at any given time is quite an arbitrary decision. As we cannot normally optimize the state of several variables at once, we have to select one variable and calculate its optimum under the conditions of the limitations created by the other variables. Research conducted in selected 
entities in the cultural sector of the Euroregion Śląsk Cieszyński showed that seven out of ten organizations try (often unconsciously) to implement more than ten strategic objectives, and these objectives are very different from one another, for example the introduction of a new offer, improving the quality of customer service, or increasing sales (Wróblewski 2016). Whether cultural entities will optimize profits, market share, or attendance during an event a concert, performance, or a festival is a decision of the directors, the organizer, management, or owners - but generally the state of only one variable can be optimized and it becomes a somewhat arbitrary, primary strategic objective, which is very often forgotten by the managers of cultural institutions. Interviews (using a questionnaire) which were carried out with directors, owners, or marketing specialists in twenty entities in the cultural sector of the Euroregion Śląsk Cieszyński showed that all the entities which were analyzed have a formulated mission, and seventeen of them also undertake strategic measures. However, it is much worse with strategic objectives formulated in writing. Out of the twenty entities surveyed, only seven declared having long-term strategic objectives formulated in writing.

Research conducted in Polish concert halls and selected entities in the cultural sector of the Euroregion Śląsk Cieszyński prove that the lack of formulated long-term strategic objectives is related to the lack of time, lack of an adequately prepared management, and a rapidly changing environment. The main factors hampering the development of strategic objectives in entities in the cultural sector are associated with adopting too many strategic objectives, difficulties in establishing the proper hierarchy of organizational goals, inadequacy with regard to the most important areas of activity of the cultural institution, and the lack of a precise definition of the expected results of its operations (Table 3.5). 
Table 3.5 Difficulties in defining strategic objectives in entities in the cultural sector

\begin{tabular}{|c|c|}
\hline $\begin{array}{l}\text { Identified by employees, managers of cultural } \\
\text { institutions, institutions in cultural industries }\end{array}$ & $\begin{array}{l}\text { Observed by the author during consultation, } \\
\text { interviews and educational workshops }\end{array}$ \\
\hline 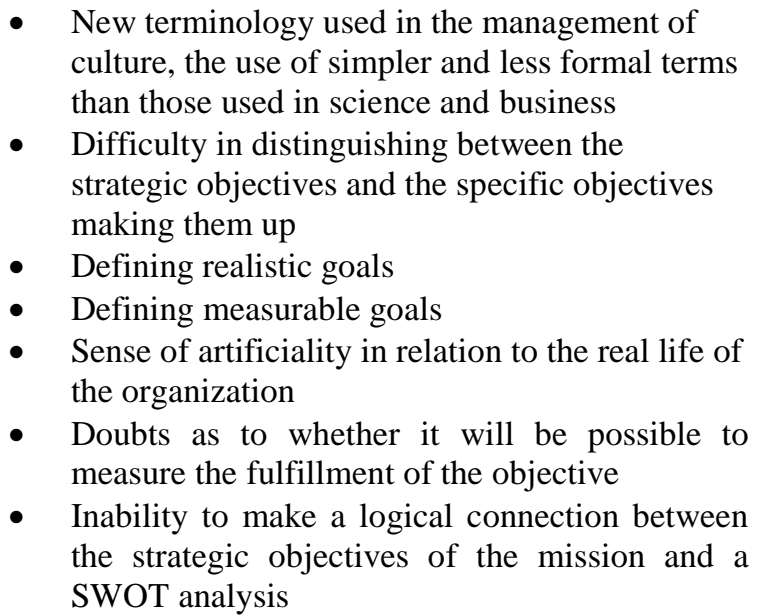 & 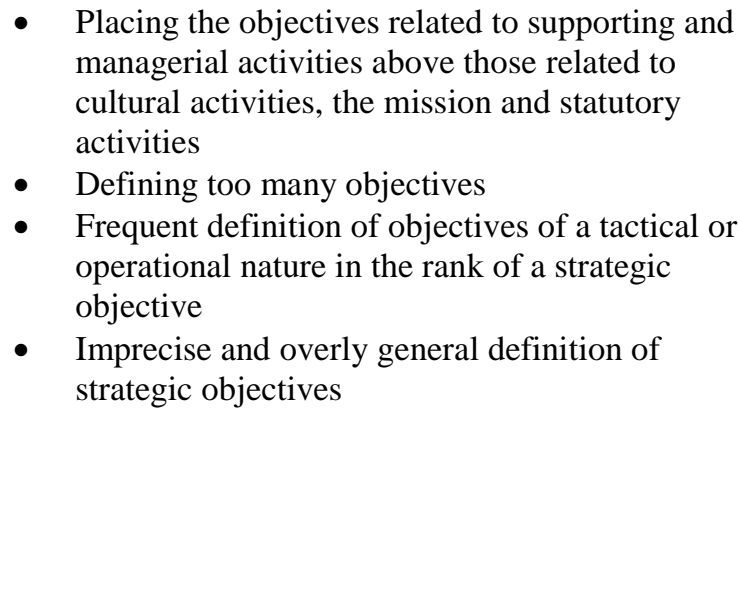 \\
\hline
\end{tabular}

When formulating marketing objectives, it must be kept in mind that the marketing strategy is part of the overall strategy of cultural institutions, an expansion of the organization's strategy, and therefore this interdependence must be reflected in marketing objectives (Figure 3.2). Marketing objectives are more specific and should therefore specify what products will be offered on what market.



Figure 3.2 Factors influencing the choice of marketing strategy in cultural institutions and cultural industries 
The selection of a particular type of marketing strategy depends on controllable factors, which primarily include conditions within the organization (e.g. a unique system of resources, skills, relationships within the organization and with the environment) and some elements of the microenvironment of entities in the cultural sector, as well as on uncontrollable factors, which include the other elements of the organization's microenvironment and all the components of its macro environment. The decision to implement a particular strategic option also depends on the concept of development and growth which has been adopted by the cultural institution or a company in cultural industries; on the other hand, the implementation of the selected option determines the development and growth of cultural entities, their pace, and their time horizon.

\section{Market segmentation in the cultural sector}

The basic premise of marketing is the need to recognize the conditions in which the organization operates, which includes the identification of consumers. It comes from the belief that the organization has the best chance of achieving its objectives when it is familiar with the needs of the consumer and tries to satisfy them in the best possible way. In the case of companies in cultural industries (business organizations), these consumers are mostly buyers of goods and services. With regard to public cultural institutions, clearly defining who the consumers are is far more difficult. This is due firstly to the nature of the organization and secondly to the type of dependencies to which they are subject. The identification and recognition of the needs of the most important customer groups of cultural institutions and then selecting the appropriate approach to them (type of marketing activities) is a key step in the process of formulating a marketing strategy. 


\subsection{Criteria for segmentation}

The consumer market of the cultural institution's offer and the offer of companies in cultural industries is extremely varied and therefore there is a need for a number of segmentation criteria. A summary of the most important criteria for customer segmentation applicable in the cultural sector is presented in Table 3.6.

Table 3.6 Types of customer segmentation in the cultural sector

\begin{tabular}{ll}
\hline $\begin{array}{l}\text { Type of } \\
\text { segmentation }\end{array}$ & Methods and criteria for dividing the market \\
\hline Geographical & $\begin{array}{l}\text { Division of the market into distinct geographical units such as nations, countries, } \\
\text { regions, provinces, cities, districts, etc. }\end{array}$
\end{tabular}

Demographic

Division of the market into groups of consumers according to demographic variables such as gender, age, family size, family life cycle, occupation, education, race, or nationality

According to age and life cycle

According to income

Psychographic

According to consumer behavior

According to purchasing opportunities

According to benefits

According to the user's status: the intensity of the user
Offering products or the use of methods of marketing influence in a way that takes into account the changing needs of consumers in different phases of their life cycle

Division of the market into groups of buyers with different incomes, relatively high, medium, or low, also indicating material conditions

Division of the market into distinct groups of buyers on the basis of their membership to a social group or lifestyle, or by personality traits

Division of the market into groups of buyers on the basis of their knowledge, attitude, etc.

Division of the market on the basis of situations in which the intention to buy a product appears, its purchase takes place or the purchased product is being used

Division of the market into groups of buyers on the basis of the different benefits that they expect from the former product; this means identifying the major benefits that people expect from the given category of products, buyers looking for all of these benefits, and the leading brands that provide them.

Division of the market into groups of buyers: those who do not use the product, exusers, potential users, new users, and those regularly using the product. In some markets, segments of customers can be distinguished based on high, medium, and low intensity of product use. Those using the product intensively are usually a small percentage of the market, but they have a large share in the total value of purchases. 
According to the degree of loyalty

According to purchasing readiness

According to the attitude towards the product
Division of the market into groups of buyers fully loyal (always using the services of the same cultural institution, loyal to one brand), loyal to a certain extent (faithful to two or three brands, products, or preferring a certain brand, but from time to time buying another) or disloyal (when buying products they choose a different brand every time or choose the one which is offered in a promotion) to their products, and then focusing on profitable, loyal consumers.

Division of the market into groups of buyers at different stages of readiness to purchase a particular product into those unaware of the existence of the given product, those conscious and interested in the product, those wanting to have it, and those who intend to buy it. The relative abundance of each of these groups has a significant impact on building loyalty programs. The stages through which the usual consumer moves when making the purchase are: awareness, knowledge, liking, preference, conviction, and purchase.

Division of the market into groups of buyers who are enthusiastic, positive, indifferent, negative, or hostile towards a given product. Attitude to the product can be an effective variable of market segmentation when marketing programs can confirm the belief of people having a positive attitude towards a product and try to convince those who are indifferent. Little time is devoted to attempting to change the negative or hostile attitude of the consumer to the product.

In order to perform a typical segmentation of the consumers of an offer of cultural entities, basic criteria for the division of customers according to certain characteristics can be used (Kolb 2005). This division should start from simple and objective criteria and end on increasingly specific and subjective criteria and characteristics, so that in the final phase of this process full information about a particular group of customers is obtained. A customer profile is created as a result of segmentation (Figure 3.3).



Figure 3.3 Types of segmentation. Source Kotler and Bloom (1984: 70) 
The choice of segmentation criteria in the entities in the cultural sector has a significant impact on the determination of strategies shaping the product of these entities and the use of other strategy elements: price, distribution, promotion, and on the selection and development of personnel. The choice of the target market should therefore be preceded by a thorough analysis of many factors, such as the size of the segments, their development prospects, the cost of reaching individual segments and their competitive position.

\subsection{Most important categories of customers in the cultural sector}

Hirschman (1993) states that in the cultural sector there are three categories of customers or levels of consumers of services (Figure 3.4). The first and second level of the consumers of a cultural offer - a consumer of the offer understood as the creator of a work of art, as well as consumers of the offer in terms of the art world - occur mainly in the case of core artistic activity. With the third level we mainly deal with consumers of culture, in the broadest sense, in the case of the remaining core artistic activity and cultural industries.

\begin{tabular}{|l|l|l|}
\hline \multicolumn{1}{|c|}{ 1st level } \\
\begin{tabular}{|l|l|} 
Author of the work \\
of art \\
(self-oriented \\
creative ability)
\end{tabular} & $\begin{array}{l}\text { 2nd level } \\
\text { People of the art world } \\
\text { (similarly oriented } \\
\text { people, other artists, art } \\
\text { critics, directors of } \\
\text { concert halls, galleries, } \\
\text { etc.). }\end{array}$ & $\begin{array}{l}\text { 3rd level } \\
\text { Wide audience } \\
\text { (commercialized } \\
\text { creative ability, } \\
\text { broadly defined } \\
\text { consumers of art) }\end{array}$ \\
\hline
\end{tabular}

Figure 3.4 Levels of the public in the cultural sector. Source Hirschman (1993: 49)

The artist who creates a certain work is directed primarily by his internal artistic needs and the desire for self-expression, therefore he is the first consumer of his art. Only later does he seek recognition or applause in similarly oriented people, people from the art world, as well as recognition from the general public (people not connected professionally with art). Additionally, it must be kept in mind that the overriding nature of the social mission of cultural institutions may cause different groups of entities to be interested in the activities, among them there are those who do not directly benefit from artistic services. This is 
determined by the phenomenon of the external effects of the use of the services, involving the occurrence of effects perceptible to third parties (Styś 1996: 120).

Hill et al. (2003: 37) noted that the consumers of cultural entities can be considered in a narrow or broad sense. They have identified the following categories of consumers in the culture sector: audiences as arts receptors, audiences as stakeholders, and audiences as customers.

According Lamons and Stewart (1983: 17-21), the category of consumers called audiences as arts receptors is formed by people directly interested in works of art. These are people who deeply experience the arts or participate in the arts. These are the people who are present in the concert hall, theater, gallery, museum not only in the "body", but also (and perhaps above all) in "spirit." For many artists this category of the audience is the most important. However, this is a very narrow understanding of the consumers of cultural institutions.

The category of consumers as stakeholders is made up of all entities directly or indirectly interested in the artistic services of cultural institutions. It must be remembered that the majority of public cultural institutions are not economically independent. This lack of independence is apparent when external funding sources - both public and private - are used. Entities supporting cultural institutions with funds and labor are treated as consumers, since in their relations with cultural institutions we can also see the characteristics of an exchange. In exchange for material resources and effort, they receive benefits of a social and psychological nature (e.g. an increase in the company's prestige, improving the image, social recognition, and personal satisfaction). This is the widest definition of the public of cultural institutions.

Audiences as customers according to Schlosser (1983: 87-98) are all entities (individuals, organizations) which are directly interested in the artistic activities (art services) of the cultural entity and are willing to pay the designated price for participation in certain artistic events. These are all people involved directly in the artistic event, regardless of whether they are capable of being active and deeply experiencing art (participation in art) or not. These people come to the concert halls, opera, theater, and galleries not necessarily for the sake of art in itself, but also for other reasons (e.g. snobbish reasons). 
One of the most important criteria for segmentation in the cultural sector is the criterion that takes into account the nature of the links between a cultural institution and its consumers. Under this criterion, it is possible to distinguish the following segments or categories of customers:

- Consumers of the cultural offer - customers;

- Local or regional community which is within the impact area of the cultural institution;

- Centers of local and regional administration and authority;

- Donors (patrons, sponsors) voluntarily supporting the activities of cultural institutions in various forms (financial, material, services);

- Professional advisers cooperating permanently or temporarily with the cultural institution;

- Entities cooperating with the cultural institution (media, suppliers);

- The internal environment created by the employees of cultural institutions: artists, administration, technical staff, etc.

The above categories of customers do not necessarily occur in the environment of all cultural entities. The importance of particular types is also the same. In the cultural sector, the presented groups of consumers have different roles. The primary group are the consumers of the cultural offer, but according to past experience related to this type of institution, the second important market of the marketing impact are donors. Both of these groups are separate customer segments that require the preparation of distinct marketing strategies by the cultural institution. With regard to cultural industries, the most important group of consumers are the buyers of goods and services; however, we should not overlook advertisers, as well as the creators of culture who decide, for example, to make a record or publish a book in a given company (a publishing house must on the one hand seek authors of valuable texts or books, and on the other hand, potential buyers of these publications). 


\subsection{Types of marketing approaches}

In determining the target market, entities in the cultural sector can opt for one of four types of marketing activities:

- Undifferentiated approach,

- Differentiated approach,

- Focused approach,

- Individualized approach (Figure 3.5).

\section{Undifferentiated activities}

Marketing mix $\longrightarrow$ Market

\section{Differentiated activities}

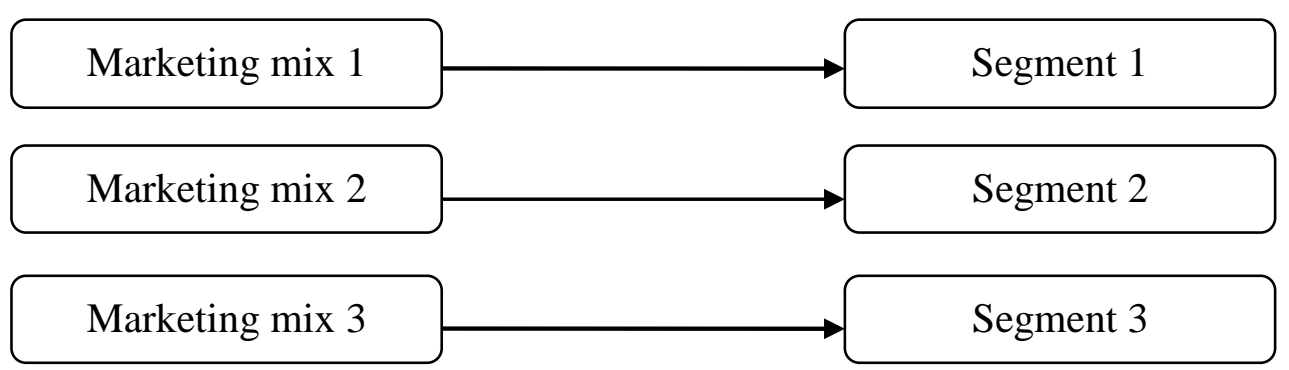

\section{Focused activities}

\section{Segment 1}

\section{Marketing mix}

\section{Segment 2}

Segment 3

\section{Individualized activities}

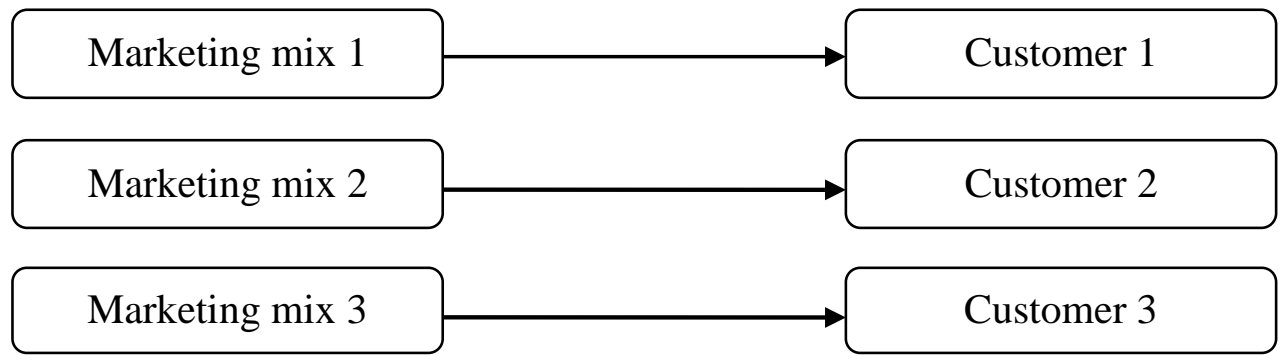

Figure 3.5 Methods of the activities of cultural entities and market segmentation. Source Garbarski (1998: 141) 
The undifferentiated approach consists of developing a single marketing strategy for the entire market. For most entities in the cultural sector, such activity could lead to failure due to the multiplicity of markets that need to be supported and the very different needs of consumers. In a developed and competitive market, also within the cultural sector, there is no concept of an average customer, and not everyone can be a consumer of the offer of cultural institutions or companies in cultural industries, or the addressee of their marketing activities. Too much time and too many resources would be needed to reach out to all clients. It would also probably turn out that all the clients mean little, because some of them are not yet interested in the offer of the cultural institution or company in the cultural industries, while others are no longer interested, and still others cannot afford to participate in cultural events or purchase this type of product. A differentiated approach seems to be much more appropriate for entities in the cultural industries as it allows for the preparation of various compositions of the marketing mix for pre-determined market segments (e.g. a separate offer for adults and children). This approach may, however, be used by institutions or companies with an established position in the market which have considerable financial resources. A focused approach is recommended for entities in the cultural sector that do not have a large budget for marketing. Their actions should then be focused on one selected segment. An individualized approach consists of treating each customer individually and adjusting the composition of the marketing mix to his particular requirements. Such an approach can be applied in relation to the donors of a cultural institution or, for example, the institutional clients of companies in cultural industries.

\section{Choosing the course of action and marketing instruments}

In shaping their marketing strategy, entities in the cultural sector (cultural institutions, companies in cultural industries) must also make decisions on how to proceed in the chosen target market. Choosing an effective course of action, which at the same time is realistic given the conditions, is determined by a number of various factors that should be comprehensively analyzed before making a final decision, the result of which will be 
specific marketing activities. In the most synthetic terms, the selection boils down to a defensive or offensive course of action. Cultural institutions and cultural industries which choose a defensive course of action recognize the preferences and needs of customers in order to meet them in an existing and unchanged manner. A trait of such a course of action is adapting the activities of the institution, company, organization, and their offer to the existing preferences and needs of the buyers (e.g. musical theaters on Broadway). Entities which choose an offensive course of action recognize the preferences and needs of consumers in order to know how to shape and create new needs. This method should be employed, in particular, by public cultural institutions whose task is to both educate and promote culture which is not only the "easy" option (e.g. musicals, commercial cinema) but also the more ambitious ones (symphonic music, opera, etc.). A feature of the offensive course of action is striving to differentiate oneself in comparison to competitors and to reduce their competitive abilities. The basis for the selection of the course of action is the information characterizing the target market, making it possible to (Wrzosek 2004: 45):

- Determine the development phase of the market, i.e. whether it is a developing or growing market, or a mature or declining one;

- Determine the degree of differentiation of buyers' expectations;

- Assess the competitive effects, in particular the likelihood of the emergence of new competitors, not only in the industry (publishing industry, audiovisual industry, etc.), but also in related sectors (e.g. tourism).

In addition, in order to select the best course of action, many factors influencing the effectiveness of the various strategic alternatives should be considered. Generally, factors that should be taken into account when choosing a particular course of action can be divided into two groups (Baruk 2001: 17):

- External factors, which are independent of the entity in the cultural sector or the dependence is negligible, therefore they can be described as uncontrollable factors;

- Internal factors, most of which are dependent on cultural institutions or companies in cultural industries, and so they have a controllable nature.

Internal and external factors determining the choice of a particular course of action in the entities in the cultural sector are presented in Table 3.7. 
Table 3.7 Internal and external factors determining the choice of a particular course of action in the entities in the cultural sector

1. The mission and objectives of the cultural entity

2. Resources of the cultural entity

3. Competences of the cultural entity

4. Feasibility and acceptance from the point of view of internal participants

5. Preferences of local authorities - the founding body, board, shareholders

6. Organizational culture

7. Organizational climate

8. Expected rate of return

9. Internal consistency of all the elements, giving a synergy effect

10. Phase of the product life cycle

Source Baruk (2001: 23)

Individual authors of papers on marketing describe different factors influencing the choice of a particular procedure, whereby this diversity arises from the application of different criteria for division, and at the same time highlights the complexity and importance of strategic marketing decisions. A summary of the criteria for the division is shown in Table 3.8 .

Table 3.8 Factors influencing the choice of the course of action

\begin{tabular}{ll}
\hline $\begin{array}{l}\text { Classification } \\
\text { according to: }\end{array}$ & Factors influencing the choice of the particular course of action \\
\hline Niestrój & - $\quad$ The degree of concentration of the competitive sector \\
$(1996: 167-173)$ & - $\quad$ Phase of the product life cycle \\
& - The development phase of the market in which the company operates \\
& - Economic conditions resulting from the current phase of the economic cycle \\
Pierścionek & - The potential of tangible and intangible assets \\
$(1996: 80-81)$ & - The possibility of obtaining the necessary resources \\
& - Organizational culture \\
& - Organizational climate
\end{tabular}

10. Business risk 


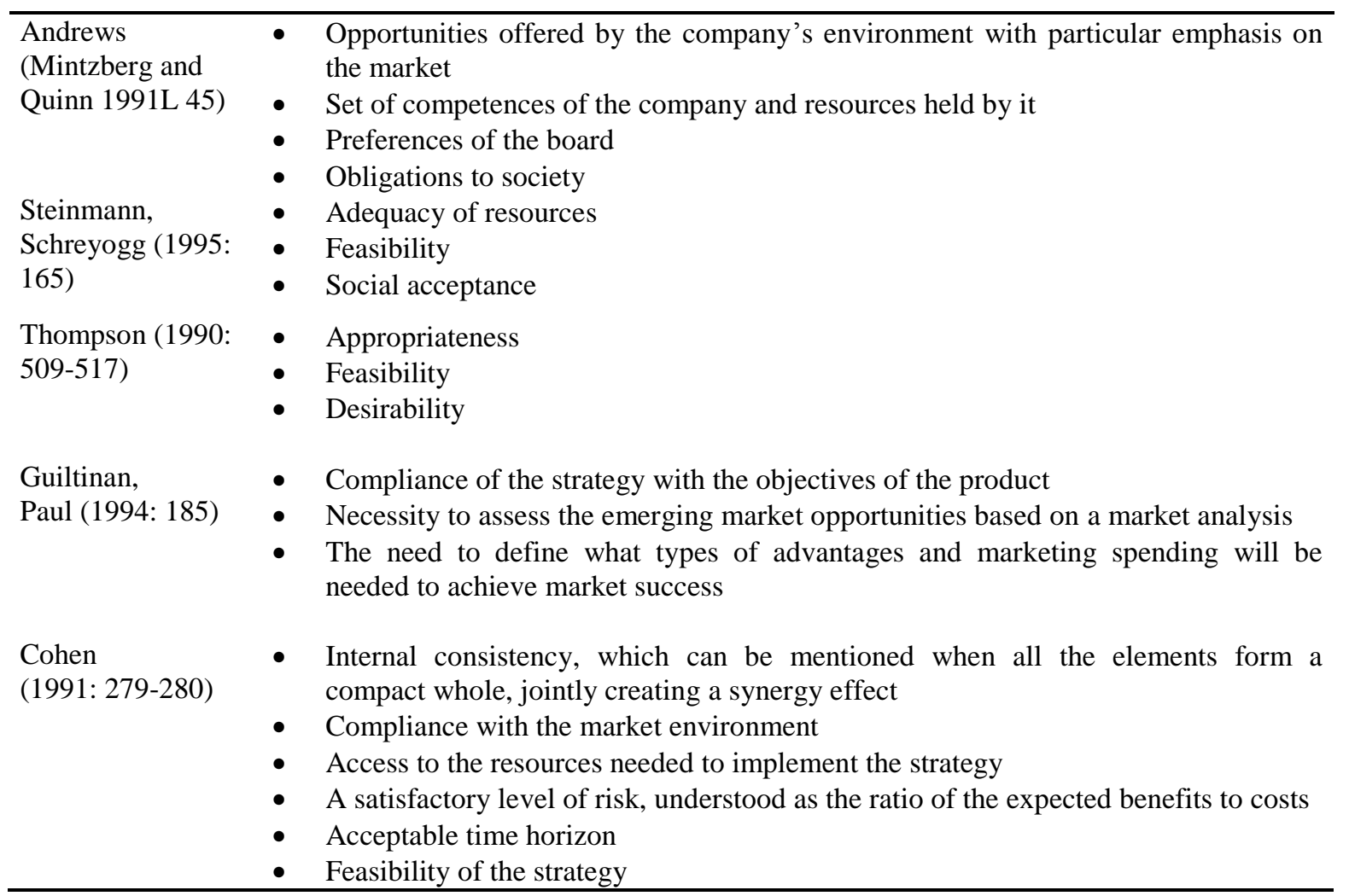

Due to the nature of the activities of cultural institutions (especially public cultural institutions), the specific products and the mission of these institutions, the offensive course of action would be more appropriate. As regards cultural industries, in many cases adopting a defensive course of action may be justified. Choosing the right course of action is based on a qualitative balancing of all the relevant aspects with regard to the economic criteria of the objective.

The stage which ends the process of formulation and the selection of a marketing strategy is to develop the marketing mix for the target segment or segments isolated in the process of segmentation, while taking into account the position which the product of cultural institutions or companies in cultural industries is to occupy in the minds of customers. When shaping the structure of marketing instruments, we should take into account the following group of conditions resulting from Wrzosek (2004: 47):

- The specific nature of the target market and the chosen course of action (taking into account the specificity of buyers making up the target market, the behavior of competitors in this market, passive or aggressive course of action); 
- The specific nature of individual marketing instruments (the mandatory or nonmandatory nature of the instruments, the varied degree of susceptibility of different instruments to changes, the varied degree of the effectiveness of marketing instruments over time);

- The essence of the concept of the marketing mix (a set of marketing instruments product, price, distribution, promotion, personnel - must be internally integrated);

- The size and structure of the resources and competences (the size and structure of resources and competences available to the cultural institution, company, organization in cultural industries determines the highest, realistic possibilities for shaping and using marketing instruments and making an impact on the market).

Shaping an efficient and effective set of marketing instruments in entities in the cultural sector is difficult, as marketing instruments are not only quantitative but also qualitative. This means that they can be subject to evaluation, but they cannot be subject to measurement. As a result, shaping an integrated system of instruments and activities is a multidimensional procedure, whose variables are stochastic in nature, therefore their impact cannot be clearly and precisely determined. The effectiveness of individual instruments is variable and depends on changes in operating conditions (Garbarski et al. 2001: 63). Typical marketing instruments, known as the marketing mix, in relation to cultural institutions and companies in cultural industries include: product, price, distribution, promotion, and staff. This five-component concept should be regarded as the most useful for shaping the marketing instruments of cultural institutions. This concept can also be successfully applied to cultural industries. Figure 3.6 graphically depicts the framework of instruments in this concept. 


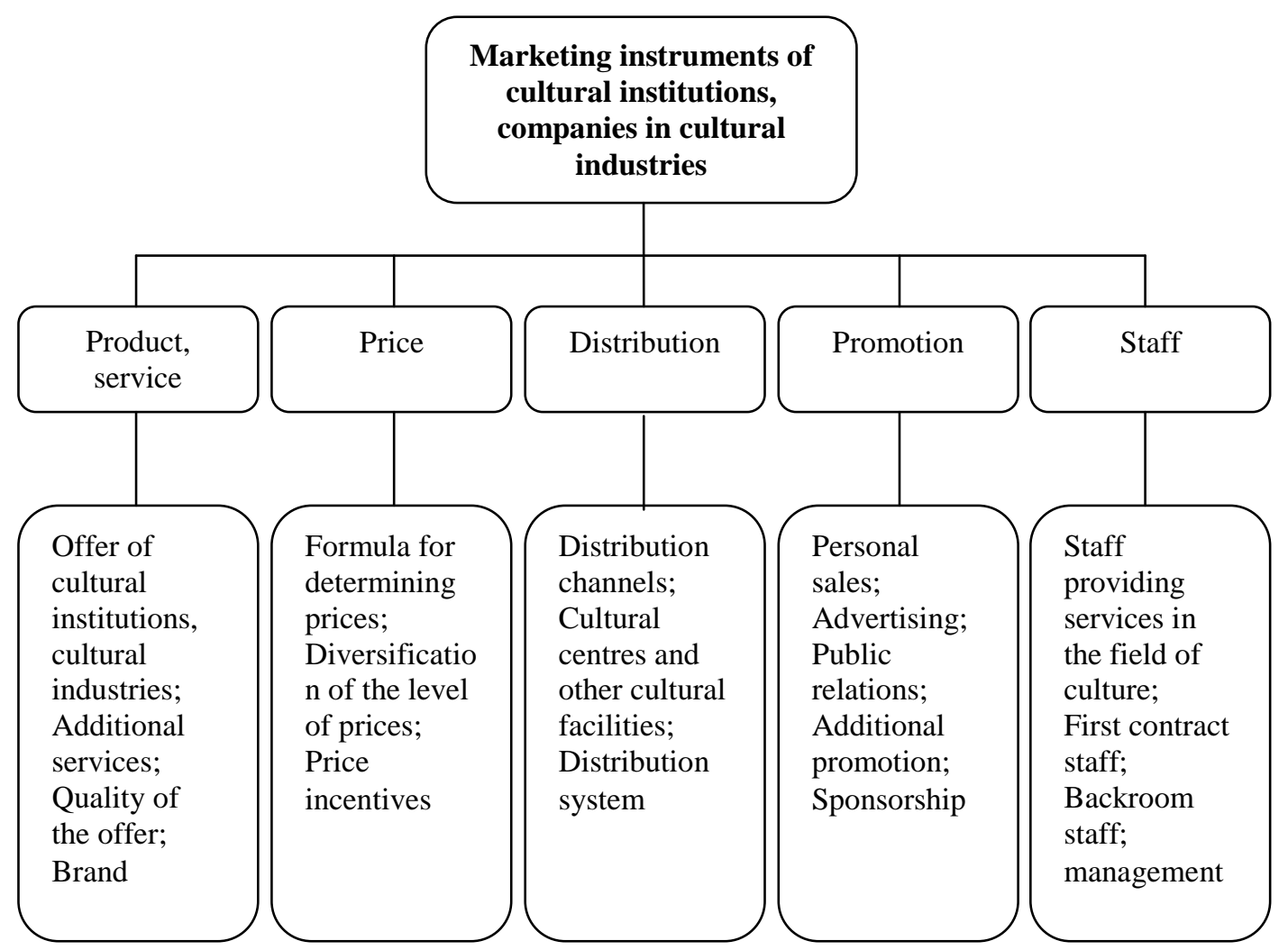

Figure 3.6 Basic instruments of the marketing mix of entities in the cultural sector

Research carried out by Sobocińska (2015) in 451 Polish cultural sector entities indicates that the marketing activities of these institutions usually consist of running their own website, cooperation with the media, or building relationships with the authorities of city or region. Table 3.9 presents the most widely used marketing activities of cultural entities within the scope of the marketing mix. They have been ranked from the most to the least frequently used by the analyzed entities of the cultural sector. 
Table 3.9 Scope of marketing activities in cultural sector entities

\begin{tabular}{|c|c|c|c|c|c|}
\hline Marketing activities &  & 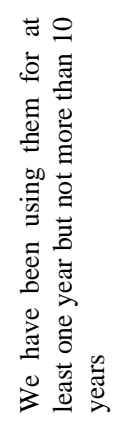 & 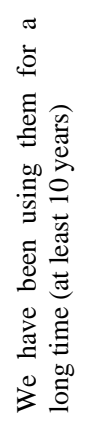 & 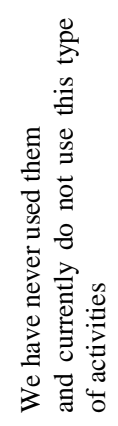 & 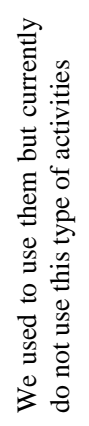 \\
\hline Having a website & 1.3 & 68.5 & 29.3 & 0.7 & 0.2 \\
\hline Cooperation with the media & 1.6 & 45.5 & 49.2 & 2.6 & 1.1 \\
\hline $\begin{array}{l}\text { Keeping good relations with the authorities of the } \\
\text { city, region }\end{array}$ & 1.6 & 37.5 & 56.5 & 3.5 & 0.9 \\
\hline Acquiring information through observation & 4.9 & 46.8 & 42.6 & 4.8 & 0.9 \\
\hline Introduction of new goods and services & 8.0 & 50.3 & 32.4 & 7.7 & 1.6 \\
\hline Attracting sponsors & 1.6 & 44.8 & 42.6 & 8.3 & 2.7 \\
\hline $\begin{array}{l}\text { Analyzing publications, press, reports about } \\
\text { culture }\end{array}$ & 3.3 & 44.3 & 40.8 & 10.5 & 1.1 \\
\hline $\begin{array}{l}\text { Advertising on television, radio, newspapers, } \\
\text { billboards }\end{array}$ & 1.8 & 49.7 & 35.5 & 10.6 & 2.4 \\
\hline Analyzing data from sales & 4.4 & 43.7 & 37.9 & 13.1 & 0.9 \\
\hline Advertising on the Internet & 3.3 & 71.2 & 10.9 & 12.6 & 2.0 \\
\hline Developing distribution channels & 4.7 & 53.9 & 23.7 & 16.1 & 1.6 \\
\hline Cooperation with universities & 3.8 & 44.1 & 33.0 & 16.0 & 3.1 \\
\hline Differentiation of prices & 5.3 & 41.0 & 32.8 & 19.8 & 1.1 \\
\hline Having a profile on Facebook & 12.9 & 62.5 & 2.0 & 22.4 & 0.2 \\
\hline Attracting volunteers & 5.5 & 46.6 & 18.0 & 25.9 & 4.0 \\
\hline Sales over the Internet & 7.3 & 56.8 & 4.0 & 30.3 & 1.6 \\
\hline Using one's own databases, CRM systems & 4.9 & 41.9 & 16.0 & 36.1 & 1.1 \\
\hline $\begin{array}{l}\text { Getting customers involved in the promotion and } \\
\text { sales on the Internet }\end{array}$ & 7.1 & 43.7 & 3.5 & 43.7 & 2.0 \\
\hline Creating fan clubs of cultural institutions & 4.0 & 29.7 & 16.4 & 44.1 & 5.8 \\
\hline The use of loyalty programs & 4.2 & 31.9 & 11.5 & 48.9 & 3.5 \\
\hline Conducting quantitative research & 7.5 & 30.6 & 8.4 & 43.9 & 9.6 \\
\hline $\begin{array}{l}\text { Conducting qualitative research (IDI, FGI, expert } \\
\text { surveys) }\end{array}$ & 8.4 & 27.5 & 7.3 & 52.4 & 4.4 \\
\hline
\end{tabular}

Source Sobocińska (2015: 215)

96 Logos Verlag Berlin - Academic Books for Sciences and Humanities 
From a marketing point of view, in cultural institutions and companies in cultural industries the product is the core business, and therefore product strategy plays a key role in these entities. This is also confirmed by the results of research carried out by the author in the Euroregion Śląsk Cieszyński (Figure 3.7).

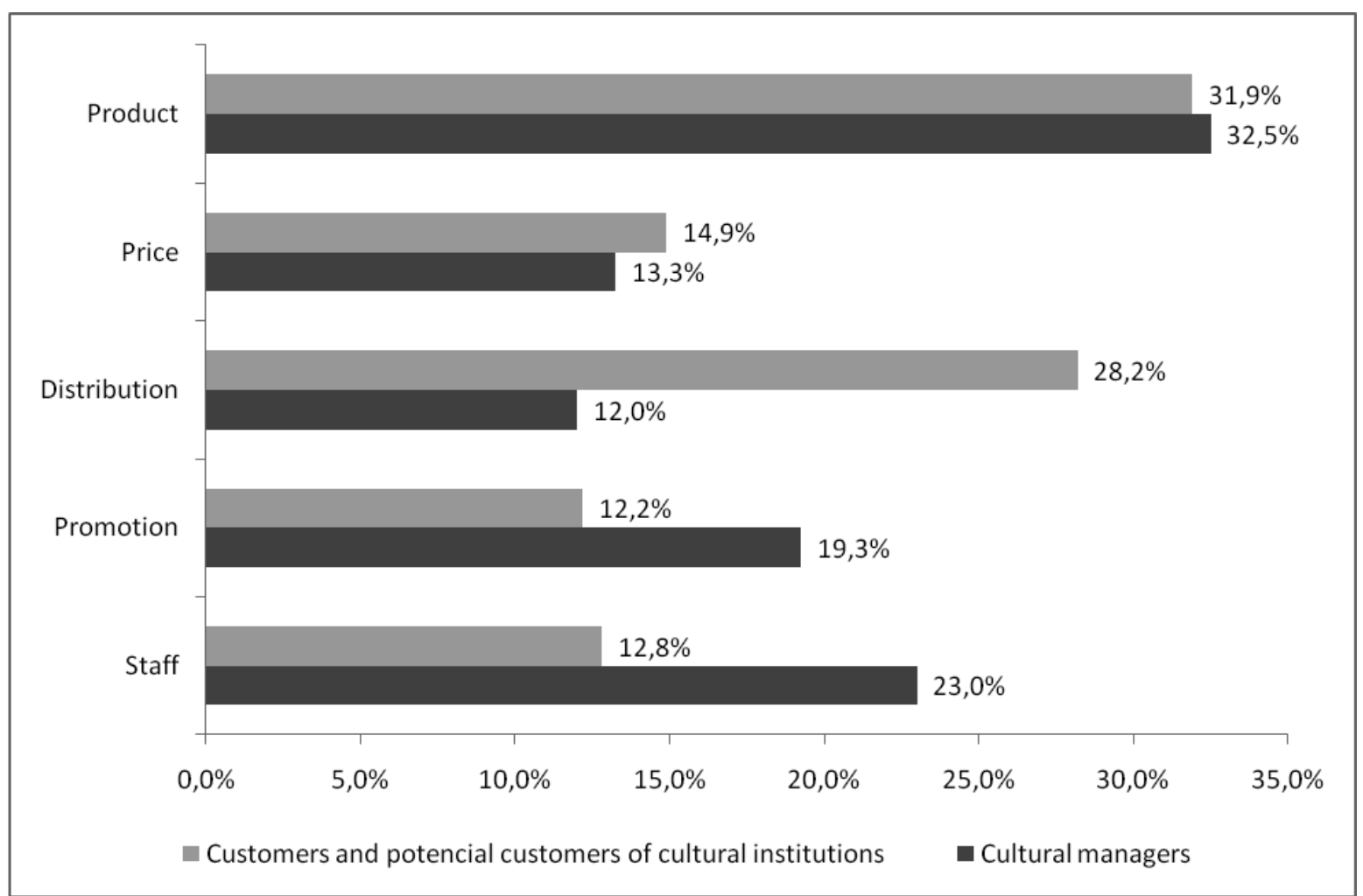

Figure 3.7 Preferred marketing mix instruments in the opinion of surveyed managers of culture, as well as customers and potential customers of cultural institutions in Euroregion Śląsk Cieszyński

According to the surveyed managers of culture, $32.5 \%$ of decisions concerning the activities from the marketing mix are concerned precisely with the product. This seems absolutely right - the largest group of potential customers of entities in the cultural sector of the Euroregion Śląsk Cieszyński which were surveyed (31.9\%) considered that, for them, the product is the most important factor in the decision-making process to purchase the product. 


\section{Models of marketing strategies of cultural institutions in relation to specified target markets}

Cultural institutions wanting to effectively disseminate culture should work on the basis of a carefully developed marketing strategy. Unfortunately, research conducted in Polish concert halls and selected entities in the cultural sector of Euroregion Śląsk Cieszyński has shown that despite the fact that all of the cultural institutions analyzed undertake marketing activities, they are mostly operational in nature, often implemented intuitively, and therefore cannot be considered as activities of a strategic nature (Wróblewski 2012, 2015, 2016). Therefore, it seems reasonable to propose model solutions of marketing strategies to cultural institutions, which can become an inherent part of their mission and strategic objectives. An example of such strategies are utility strategies, relating to specific target markets.

\subsection{Characteristics of the analyzed target markets of cultural institutions}

Taking into account both the artistic and aesthetic competences of the consumers of the cultural offer (those present and potential), and the intensity of marketing activities in cultural institutions, four main customer segments can be identified:

- People associated with art professionally,

- People with a positive attitude towards art,

- People indifferent to art,

- People reluctant towards art.

People associated with art professionally are a customer segment which is often included in the so-called art world (artists, critics, employees of cultural institutions, etc.), which evaluates the artistic offer and often determines the success of a given artistic project (which in turn can translate into financial success). This segment has the expertise necessary for the proper reception of art and is knowledgeable about both the market for the creation and dissemination of art. Therefore, in comparison with other segments, it is relatively insusceptible to the marketing activities of cultural institutions. This group primarily looks 
for information about the artistic offer in traditional media, on the Internet, and in magazines devoted to cultural issues. It makes its market decisions autonomously and when choosing a cultural event to participate in, it is directed primarily by the message of the work and its content, which is much more important than the promotion of the event, or the price of admission. These customers have a high level of requirements and highly diverse expectations, not all of which can be met by cultural institutions. These are people for whom being with art is a way of life, and the main motivation for participating in a particular artistic event is intellectual development and communicating with authors, artists, and other people.

People with a positive attitude towards art create a segment not professionally involved with art, but participating in the artistic events organized by cultural institutions. Cultural needs occupy a relatively high position in the hierarchy of values in their life, but compared with the previous segment, their spending on culture is lower. It should be noted that although such forms of activity like going to a museum, gallery, concert hall, opera, or theater are considered by this group of people as valuable, they are not implemented frequently. When choosing an artistic event in which they will participate, in addition to the content and message of the work, they often pay attention to comfort. In making their purchasing decisions, a significant role is played by the place where the artistic event will take place. It should also be noted that these customers are sensitive to the promotion of a cultural event and the artistic offer of cultural institutions is more suited to their expectations. Therefore, convincing them to participate in a particular artistic event should not pose a major difficulty to the institutions. This group, compared with people associated with art professionally, is somewhat less prepared for the reception of art, so next to individual development and leisure, the main motivating factor for participation in an artistic event is cultural education.

Those indifferent to art are a segment of customers who occasionally participate in cultural events, especially high culture (opera, philharmonic, ballet, etc.). In comparison with the previous segments of customers, the cultural needs of this group occupy a low position in the hierarchies of their life values and are felt with a lower intensity. Their market decisions depend to a greater extent on the price and the places where the cultural event will be held. Expenditures on participation in culture are at a relatively low level. However, among the 
behavioral patterns of a large part of this group, attention should be paid to the display effect (snobbery), which can be interpreted as a regularity describing the tendency of the customer to be similar to others (e.g. frequenting exclusive symphony concerts or openings, where one can meet members of groups with higher incomes or higher social prestige). This group is particularly vulnerable to the marketing activities of cultural institutions. This group seeks information about the cultural offer above all in the press and on television and the family is also a source of information. It should be emphasized that they do not read magazines devoted to cultural issues.

The group reluctant towards art is the least educated segment and at the same time the worst prepared for the reception of art. Deficiencies in education, in particular concerning knowledge of culture, often lead to a misunderstanding of art which, in turn, creates an aversion towards it. This is a group of people who are not interested in events in the field of culture, as they often perceive them as boring, designed for social elites or snobs. Therefore, the activities of cultural institutions must be aimed at changing this specific group's perception of the institution itself and its offer. This task is very laborious, time consuming, and also very expensive. This group, although it is a strategic challenge for many cultural institutions, cannot constitute the main segment on which these institutions focus their marketing efforts.

Through separating the market segments presented, as well as determining the direction in which the cultural institution's artistic offer is moving (elitism, popularity), it is possible to use one of the following four marketing strategies:

- Elitist art strategy,

- Art emphasizing strategy,

- Strategy of increasing sensitivity to art,

- Art popularization strategy.

The elitist art strategy is mainly designed for people associated with art professionally. In relation to people with a positive attitude towards art, the use of the art emphasizing strategy seems to be the most appropriate. In regard to those indifferent to art, the strategy for increasing sensitivity to art should be used, and for people reluctant to art, the art popularizing strategy. 


\subsection{Elitist art strategy}

The implementation of the elitist art strategy by the cultural institution is associated with the development of an artistic offer of the highest quality. The priority of this strategy is to popularize works of art whose level can match that of global cultural heritage and revive and enhance it. This is achieved through patronage extended by the cultural institution to the most valuable works of global cultural heritage, individual creators, and artists with significant achievements, or by promoting new prestigious investments, unique at an international level (e.g. the organization of an international music festival, competition or building a new museum, theater, opera house, concert halls).

The marketing is focused on a relatively narrow group (mostly people associated with art professionally), which is looking for an original, exclusive offer of the highest quality, made up of both classic works of art, as well as modern/avant-garde ones. Therefore, the strategy may be used by cultural institutions focused on marketing which, when seeking market opportunities, often market a new offer, paying particular attention to its acceptance by the public. Addressees of the elitist art strategy are mostly well off, therefore according to Engel's law, the Katona effect, as well as the Veblen paradox, they are willing to allocate more funds to satisfying their needs in the field of culture. This fact, as well as an original cultural offer of the highest quality, entitles the cultural institution to use a prestigious price strategy, which makes it possible for the organization to achieve a satisfactory income. In the elitist art strategy it also seems to be the most appropriate to use the exclusive distribution strategy, the informing promotion strategy, and the image promotion strategy, as well as the strategies of soliciting employees. However, other combinations are possible. It is very important that marketing activities facilitate the creation of a positive image of the cultural institution, which is both exclusive and prestigious.

The most important advantage of using this strategy is the originality and high quality of an ambitious artistic offer. One of the main disadvantages is the high price, which is a barrier to accessing culture for those less privileged. Therefore, national cultural institutions that want to effectively promote culture in society should not only use this strategy. It seems 
necessary to combine it with the art emphasizing strategy, or even with the strategy of increasing sensitivity to art.

\subsection{Art emphasizing strategy}

The art emphasizing strategy is addressed to people with a positive attitude towards art, and its main goal is to distinguish the artistic offer of the cultural institution from competing products. Institutions seek to create such a position of their offer in the minds of buyers that it is seen as exceptional or even unique. Essentially, this should not pose major problems since cultural institutions, as one of the few, uphold the highest values through their activity. Theodor Adorno (1991), the author of the most systematic and most critical analysis of popular culture, and also high culture, says that in contrast to popular music - the reception of which is always passive, endlessly repeated, confirming the world as it is - art, for example symphonic music, refers to the pleasure derived from the imagination, proposing participation in a world as it could be (Storey 2003: 89-94). Therefore, this is a strategy in which a very important role is played by the positioning of the artistic offer. The positive perception of art and the positive attitude of the client in relation to the artistic offer results in the customer's readiness to a specific behavior, e.g. formulation of the intent to make a purchase or making a purchase. Using this strategy, however, requires the cultural institution to move away from the passive transmission of information and replace it with stimulation and developing the ability to have a deeper participation in art, and also an individual understanding of the phenomena, processes, and people who create it. At the same time, this cannot be easily absorbed into the institution's specific programs and activities. Employees of cultural institutions, in addition to personal predisposition, must have enormous substantive knowledge, abilities, and real skills, e.g. to take innovative, creative actions in addition to those basic ones related to reawakening and stimulating individual needs and interests. Institutions wishing to apply this strategy should strive for maximum penetration of the current market through appropriate promotional activities (mainly the strategy of building loyalty) and distribution activities (the strategy of selective distribution). 
It is also possible to achieve through the use of the neutral price strategy, which is based on the prices of competing products.

The main advantage of the art emphasizing strategy is that it puts a lot of emphasis on the development of long-term relationships between the cultural institutions and the existing customers of their offer. Unfortunately, acquiring new customers of the artistic offer is a secondary issue here, which is its weakness.

\subsection{Strategy of increasing sensitivity to art}

Hypothetically, it can be assumed that every person is sensitive to art, regardless of the level of culture, profession, environment, etc., but it must be added that this trait is not stable and is easily influenced by all these factors which affect the human psyche. It is formed through contact with art, acquiring experiences, and broadening the scope of reflection on artistic phenomena and, although it manifests itself spontaneously, it cannot occur without the appropriate stimuli. What stimulates it is the specific qualities of objects, e.g. rhythmic or expressive qualities, and particularly complicated structures occurring in art, harmonious or disharmonious, referred to as aesthetic structures (Gołaszewska 1986: 287). The purpose of the strategy of increasing sensitivity to art is therefore to bring the people who are indifferent to art into contact with the offer of cultural institutions more frequently, and consequently stimulate their sensitivity to art. These activities rely heavily on ensuring the proper distribution of tickets and, more importantly, the services themselves. The cultural institution, in order to popularize its offer among the broadest possible group of people indifferent to art and to stimulate their ability to interpret art, should organize artistic events not only in its headquarters, but also in places closer to the target group (schools, workplaces, or churches). It is also important that the distribution of services (the selective distribution strategy) is supported by appropriate pricing strategies. It seems that the most appropriate strategy is the compensation price strategy, but promotion strategies, in particular the stimulating strategy, can be adopted. 
An important advantage of this strategy is that the cultural institution has the possibility of obtaining a customer segment which has not participated regularly in cultural events before, while the disadvantage is the relatively high cost of customer acquisition in relation to the low revenues earned from ticket sales.

\subsection{Art popularizing strategy}

A person's response to external stimuli regarding art (a cultural institution's offer) can be negative (Niemczyk, 2007: 25). This reveals itself in perceiving certain negative attributes of a given product; expressing negative feelings towards the product; demonstrating a tendency to avoid the acquisition of the given services (Barbeka 2004: 53).

In such cases, cultural institutions should adopt the art popularizing strategy. Its main purpose is to change the image of the organization, resulting in a change in the perception of the institution and its offer in the minds of customers. It must be remembered that in the cultural sector, we come into contact with certain psychological regularities of customer behavior. For example, a regularity consisting in assigning certain characteristics to products according to their appearance and other physical properties is very important. The assessment of a given object is made from the point of view of social judgments, which are considered correct and valid (Drab and Wielgus 1993: 76-84). It is widely recognized, for example, that formal attire is required in the opera or concert hall which, for a certain group of customers, can be embarrassing. In other words, a cultural institution must attempt to change the beliefs of the customer through its impact on the cognitive element of the customer's attitude or to change the customer's feelings, which affect his emotions (e.g. ambition aspects), or attempt a simultaneous change of beliefs and feelings. To achieve this, modification appears necessary, as well as the adaptation of the cultural institution's existing products to existing attitudes. This, however, poses a risk that they will become closer to entertainment than art. At the same time, it is necessary to use intensive distribution, which offers potential customers the possibility to come into contact with the institution's offer in places not yet associated with high culture (stadium, park, town square, etc.). 
The appropriate shaping of price is also important. It should not be a barrier in the decisionmaking process on participation in an artistic endeavor and therefore the symbolic (minimum) price strategy seems the most appropriate. Of course, a special role in promoting art is played by appropriate promotion, which should be directed at changing the image of the cultural institution.

The main advantage of the popularization strategy is that the perception of the institution and its offer is altered by those people who have a reluctant attitude to art. This, in turn, leads to changing the attitude from reluctant to neutral or even to positive. Its most significant drawback is the commercialization of the cultural institution's offer, due to which it begins to manifest qualities closer to entertainment than art.

\section{Problems with the implementation of marketing strategy in entities in the cultural sector}

Interviews conducted both in Polish concert halls and selected entities in the cultural sector of the Euroregion Śląsk Cieszyński (Wróblewski 2016) indicate that marketing strategies are identified continuously by a significant number of cultural managers (especially art directors) by using different sales and advertising techniques (nearly $73 \%$ of the concert halls analyzed) or even a set of gimmicks and tricks aimed at persuading the customer to participate in a particular artistic event. Acceptance of the use of marketing in the cultural sector is significantly delayed because of this. This is often the cause of a so-called vicious circle which occurs in the process of implementing the marketing strategy in the cultural sector. The confirmation of this thesis is the fact that in 17 Polish concert halls, where employees of marketing units were responsible for the implementation of the marketing strategy, the biggest implementation problems were considered to be:

- Lack of financial resources for the implementation of the strategy;

- Staff shortages, frequent staff turnover;

- Lack of proper communication between the marketing department and the arts department; 
- Blurring the responsibility for the implementation and execution of the strategy;

- Skeptical attitude of artistic management to strategic marketing;

- Lack of the artistic staff's trust in marketing.

The results of the research carried out in Polish concert halls can also be extended to other cultural institutions (e.g. theaters, opera houses, museums). The vicious circle in the process of the implementation of the marketing strategy in the entities in the cultural sector is shown in Figure 3.8.

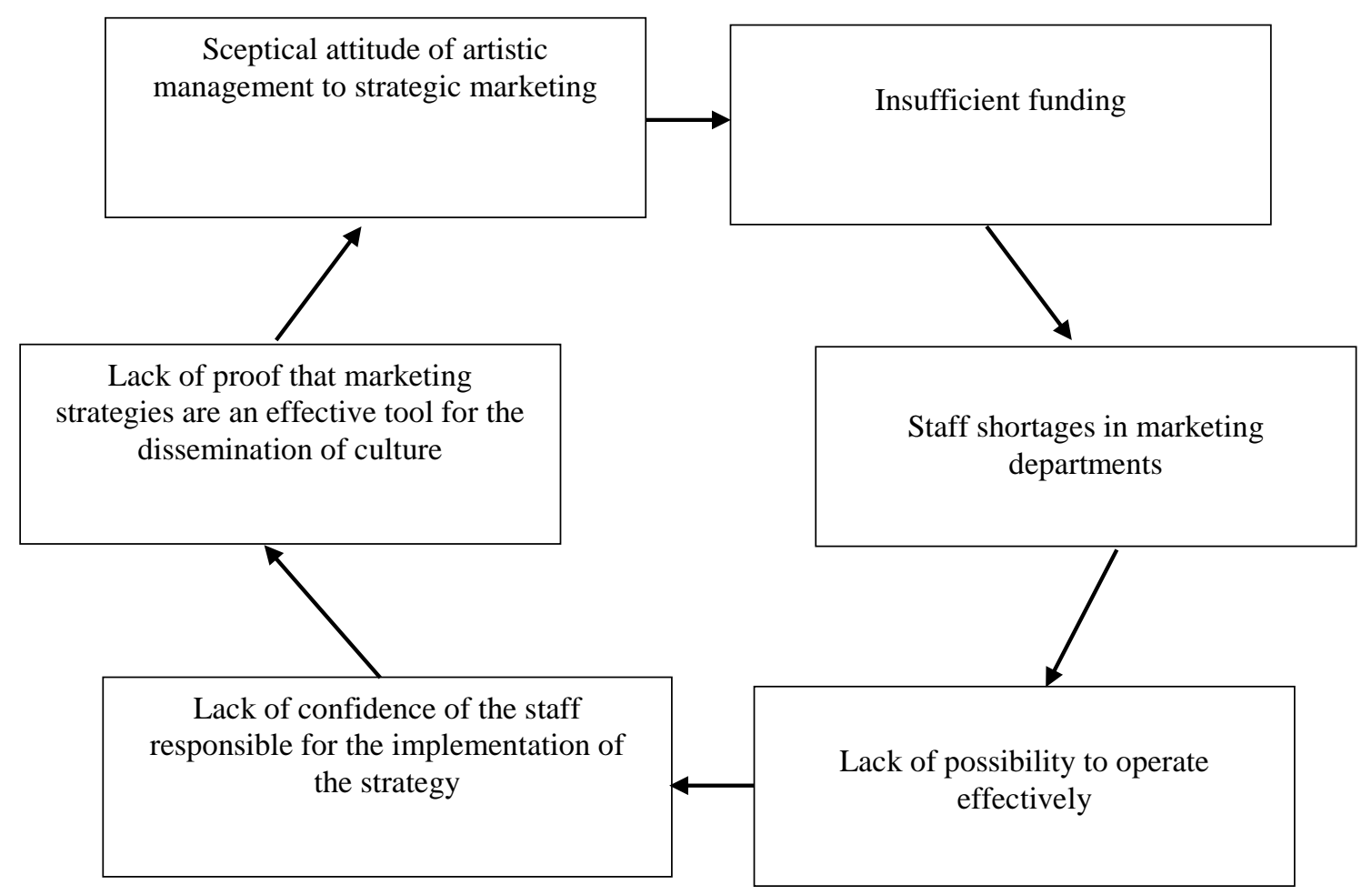

Figure 3.8 The vicious circle in the process of the implementation of the marketing strategy in the cultural sector

Even if the managers of cultural entities recognize the importance of a marketing strategy, the level of funds which they are willing to spend on its implementation is too low. This largely stems from the under-funding of these institutions by the state, as well as difficulties in raising funds from donors. This in turn leads to staff shortages in marketing departments (the employees in these departments are responsible for the implementation of marketing strategies), and sometimes the lack of a marketing department. Employees of 
cultural entities which are located in smaller cities often do not have adequate training in the field of strategic or marketing management, and their activities are limited to the development of promotional programs or the distribution of tickets. The situation is much better in institutions located in big cities or important cultural centers, but here there are often problems with the funding of marketing activities, with the effect that the staff is unable to effectively "sell" their activities, and this in turn means that the employees lack confidence in themselves. As they do not feel that they could have an effect on the success of their institution, they put less emphasis on the implementation of the marketing strategy and monitoring its implementation. In consequence, without the full implementation of the marketing strategy and the effective monitoring of its implementation, there is no method to convince top management to conduct marketing activities (develop, implement, and consistently maintain the marketing strategy). As a result, management becomes more and more skeptical about the contribution of the marketing department and the advisability of investing funds into it. This results in insufficient resources being allocated for this purpose, and the whole process repeats itself. 


\section{References}

Abell D.F. (1980), Defining the business: the starting point of strategic planning, Prentice Hall, Englewood Cliffs

Baruk A. (2001), Dynamiczne kształtowanie strategii marketingowej firmy: Uwarunkowania strukturalne i procesowe, Wydawnictwo Adam Marszałek, Torun

Cohen W. (1991), The practice of marketing management, Macmillan, New York

Frank R.E., Massy W.F., Wind Y. (1972), Market Segmentation, Prentice-Hall, Inc., Englewood Cliffs

Garbarski L. (1998), Zachowania nabywców, PWE, Warszawa

Garbarski L., Rutkowski I., Wrzosek W. (2001), Marketing: Punkt zwrotny nowoczesnej firmy, PWE, Warszawa

Guiltinan J.P., Paul G.W. (1994), Marketing management: Strategies and programs, McGraw-Hill, New York

Hill L., O’Sullivan C., O’Sullivan T. (2003), Creative Arts marketing, Linacre House, Jordan Hill, Oxford, Burlington

Hirschman E.C. (1993), 'Aesthetics, ideologies and the limits of the marketing concept', American Marketing Association Journal of Marketing, Vol. 47

Kolb B.M. (2005), Marketing for Cultural Organizations: New strategies for attracting audiences to Classical Music, Dance, Museums, Theater and Opera, Thomson Learning, London

Kotler P. (1994), Marketing, analiza, planowanie, wdrażanie i kontrola, Gebethner i Ska, Warszawa

Kotler P., Bloom P.N. (1984), Marketing professional services, Prentice-Hall Inc., Englewood Cliffs

Lambinn J.J. (2001), Strategiczne zarządzanie marketingowe, PWN, Warszawa

Lamons M., Stewart S. (1983), Theater: the vital relationship, Foundation for the Extension and Development of the American Professional Theater, New York

Limański A., Drabik I. (2007), Marketing w organizacjach non-profit, Difin, Warszawa

Minzberg H., Quinn J.B. (1991), The strategy process, contexts, cases, Prentice-Hall, New Jersey

Niestrój R. (1996), Zarządzanie marketingiem: Aspekty strategiczne, PWN, Warszawa

Nowotarska-Romaniak B. (2003), Marketingowa orientacja firm ubezpieczeniowych w Polsce, Wydawnictwo

AE w Katowicach, Katowice

Obłój K. (2007), Strategia organizacji: W poszukiwaniu trwałej przewagi konkurencyjnej, PWE, Warszawa

Pierścionek Z. (1996), Strategie rozwoju firmy, PWN, Warszawa

Schlosser R.J. (1983), Audiences: Market the arts, Foundation for the Extension and Development of the American Professional Theater, New York, pp. 87-98

Simon H. (1964), 'On the Concept of Organizational Goal', Administrative Science Quarterly No. 9 
Steinmann H., Schreyogg G. (1995), Zarzqdzanie: Podstawy kierowania przedsiębiorstwem, Oficyna Wydawnicza Politechniki Wrocławskiej, Wrocław

Styś A. (1996), Marketing ustug, Wydawnictwo AE we Wrocławiu, Wrocław

Thompson J.L. (1990), Strategic management: Awareness and change. Chapman Hall, New York

Wróblewski Ł. (2016), Marketing strategiczny w sektorze kultury Euroregionu Śląsk Cieszyński, CeDeWu, Warszawa

Wrzosek W. (ed) (2004), Strategie marketingowe, PWE, Warszawa 



\section{Chapter 4}

\section{Marketing strategies based on relationships with key market participants}

\section{The process of forming relationships}

Changes taking place in the cultural sector (growing competition, the virtualization of consumption, development of new technologies, and globalization) clearly show that cultural institutions must create long-term relationships with both customers of culture, as well as other market participants (e.g. donors or employees), in order to secure their future existence. The traditional concept of marketing is increasingly being criticized. The cultural institutions which use classic marketing primarily focus on acquiring as many new customers or donors as possible, often neglecting their present, often most valuable customers. The concept of relationship marketing enables us to take a modern look at the nature of the interactions and relationships between the cultural institution and the various entities occupying its environment, and therefore is well suited for use in the cultural sector (Sobocińska 2015, Peck et al. 2013, Wróblewski 2012, Palmatier et al. 2008, Grönroos 2004).

Relationship marketing is a marketing concept which has been developing since the early 1980s and is currently considered to be the dominant paradigm in this field, gradually displacing the concept of transaction marketing (Hollensen 2015, Egan 2008). In relation to the services market, the change in marketing towards building lasting relationships with customers came in 1983 when Berry (1995: 236) first described the whole concept of relationship marketing as a concept for the management of a services company. $\mathrm{He}$ distinguished five strategic elements of the application of relationship marketing, which today represent the theoretical basis of the concept: developing core services, adapting the 
offer to the expectations of the individual customer, enriching the core service with special benefits (added value), pricing to stimulate consumer loyalty, and undertaking intensive marketing activities in regard to one's own employees.

Building lasting relationships is a continuous process and does not end when a customer is persuaded to participate in an artistic event, a donor to give his support, or an artist is persuaded to become involved in a particular project. Forming long-lasting relationships goes beyond a single transaction and is cyclical in nature. This means that the cultural institution and its clients (consumers of the cultural offer, donors, employees) pass through successive, repeated stages. If the course of a given cycle of the relationship is undisturbed, the partners in the exchange start a new cycle. Passing through subsequent cycles is a prerequisite for the continuation of the relationship (Claycomb and Martin 2013). The process of cultural institutions building long-term relationships with the consumers of cultural offers, donors, and employees is presented in Figure 4.1.

In the process of building long-term relationships, we can distinguish two main phases: the initial phase - the creation of a relationship (this phase ends when a customer is persuaded to participate in an artistic event, a donor gives his support to the institution, or a contract is signed by an artist with the cultural institution) - and the main phase of strengthening of the relationship (which is a closed cycle and continues for a longer time). The main objective of the initial phase is for the cultural institution to establish ties with selected customers (consumers of the offer, donors, employees). This phase can be divided into three stages: the first stage consists of identification of target customers, the second stage of offering value to potential customers (the main benefit), and the third stage of acceptance of the cultural institution's offer by the customer (or its rejection) and their decision to purchase the services, grant support, or sign a contract with the cultural institution. The initial phase of building a relationship is therefore synonymous with the classic marketing process. 




Figure 4.1 The process of cultural institutions building long-term relationships with the consumers of artistic offers, donors and employees

A characteristic feature of the main phase is the cyclical implementation of subsequent stages of relationship marketing: creation and delivery of value, re-offering value, accepting value, creation of and delivering value, etc. This is the basis on which the relationship is continued and deepened. In this phase, the consumers of the cultural offer, donors and 
employees, beside the main benefits are offered additional benefits by the cultural institution, such as a special acknowledgement or distinctions for the sponsors, or loyalty programs and prizes for employees. Breaking this cycle means breaking the relationship between the cultural institution and the client. Therefore, it is important to constantly monitor the process of relationship marketing, and not only the achievement of the objectives of the cultural institution, but also to constantly monitor the so-called critical moments, such as the rejection of the value offered by the cultural institution (Kinard and Capella 2006). Source literature provides a rich set of measures for strengthening relationships (Hollensen 2015, Peck et al. 2013, Palmatier et al. 2008, Egan 2008, Grönroos 2004). The most important of them are presented in Table 4.1 .

Table 4.1 Definitions of the measures of the strength of a relationship between cultural institutions and the consumers of the offer, donors, and employees

\begin{tabular}{|c|c|}
\hline Measure & Definition \\
\hline $\begin{array}{l}\text { Duration of the } \\
\text { relationship }\end{array}$ & $\begin{array}{l}\text { Period counted from the first transaction of the client, donor or artist with a cultural } \\
\text { institution }\end{array}$ \\
\hline $\begin{array}{l}\text { Intensity of the } \\
\text { relationship }\end{array}$ & $\begin{array}{l}\text { The frequency with which, in a given period of time, the cultural institution is in } \\
\text { contact with the consumers of the artistic offer, donors and artists directly "face to } \\
\text { face", by telephone and via the Internet }\end{array}$ \\
\hline Comparative benchmark & $\begin{array}{l}\text { The way in which the consumer of the artistic offer, donor, or artist evaluates the } \\
\text { likelihood of replacing the current cultural institutions with another institution, with } \\
\text { which maintaining a relationship would be more beneficial }\end{array}$ \\
\hline $\begin{array}{l}\text { Professional knowledge } \\
\text { of the cultural institution }\end{array}$ & $\begin{array}{l}\text { The way in which the consumer of the artistic offer, donor or artist evaluates the } \\
\text { level of expertise of personnel and the ability to transfer this knowledge in mutual } \\
\text { contacts }\end{array}$ \\
\hline Trust & $\begin{array}{l}\text { Convincing the consumer of the artistic offer, donor or artist that the promises made } \\
\text { by the cultural institution will be fulfilled }\end{array}$ \\
\hline Involvement & $\begin{array}{l}\text { Positive, neutral or negative emotional attitude of the consumer of the artistic offer, } \\
\text { donor or artist towards contacts with the cultural institution }\end{array}$ \\
\hline
\end{tabular}

The inclination of the consumer of the artistic offer, donor or artist to develop the relationship is determined by their beliefs and emotions regarding the cultural institution and has been shaped by the previous interactions. Therefore, the creation of long-lasting relationships in cultural institutions requires a departure from the traditional way of doing 
business. The basis of such a system is to create exceptional values for the consumer of the artistic offer, donor, or artist, rather than maximizing profits.

\section{Shaping relationships with consumers of the cultural offer}

In the cultural sector, the consumer of the cultural offer is the ultimate verifier of the efficiency and effectiveness of the cultural institution. The opinions, attitudes, and behaviors of customers in the market determine the position of a cultural institution. The customer's decision-making process is affected by the overall evaluation of the cultural institution, in regard to, for example, the program it offers, the efficiency of the service, and the efficiency of the communication system. Information about the factors which affect the customer's selection process is particularly important. This information is collected by the cultural institutions in order to serve as many satisfied customers as possible. Only a sufficiently high level of satisfaction with the cooperation leads to maintaining contacts, repeated purchases and, as a result, customer loyalty to the artistic organization. Hence, building long-term and lasting relationships with consumers of the artistic offer is a special area of interest for cultural institutions (Ha and Stoel 2008, Palmatier et al. 2007, Ndubisi 2006).

The building of lasting relationships by a cultural institution with the consumers of its offer is a process that may take the form presented in Figure 4.1. In the initial phase of the process of building relations, in order to make the correct identification of target groups, it is necessary to carry out customer segmentation. The example of the segmentation of consumers of musical institutions (e.g. opera, concert hall), presented in Figure 4.2, shows the desired structure of current and potential consumers of the cultural offer. 




Figure 4.2 Pyramid of opera and concert hall goers

This form of segmentation allows the most valuable (profitable) consumers of the cultural offer to be distinguished. Commercial companies are, of course, familiar with the Pareto principle and consciously focus efforts on those customers who generate the most income. However, it seems that a significant number of cultural institutions do not benefit from this knowledge. If some segments of the population can be considered as regularly attending symphony concerts, opera, or theater, they should be the object of special efforts. Such segments, by their very nature, are the easiest to encourage to participate and they can develop properly over time. However, Dawson (Mokwa et al. 1980: 7) draws attention which can be considered a paradox in marketing culture - to missionary efforts which aim to develop the audience among those marginally interested in art and almost neglect efforts to ensure the strongest possible reaction from that segment of society which would be most 
willing to support it. Many cultural institutions still do not see the need to focus on those customers who represent the greatest potential for them. Sargeant (2004: 236) points out that the client who spends nearly 500 pounds per year on culture is worth more than one that spends five pounds during the same time period. Unfortunately, many conservative artistic directors regard this as heresy, but wrongly so. Carefully winning over the most valuable customers can bring valuable income which can be allocated to the more missionary aspects of the organization.

A key element of the initial phase of building lasting relationships with customers is the concept of value (benefits). Once the target audience of the cultural offer has been correctly identified, they should be offered a certain value. It should be remembered that value is determined not only by the service the customer receives. Equally important is the way the service is received, and to be precise, the quality of the process of interaction and dialogue with the customer (Grönroos 2004, Furtak 2003). The effect of the exchange of tangible and intangible values is customer satisfaction, trust, and commitment to the service provider. The perceived value of maintaining a relationship with a cultural institution is therefore the sum of the basic and additional value. The basic value concerns the most important benefits which are experienced from contact with the cultural institution. For example, in the case of a concert hall, the sense of basic value, the most important benefit, can be understood by answering the question of what the consumer of a cultural offer actually buys or what are the basic needs he intends to satisfy when selecting a symphonic concert. It turns out that the basic value (most important benefit) that is offered by a cultural institution is linked very strongly with the core of the product and, depending on the consumer's needs, can take different forms. Examples of linking the core of the product with the main motive for participating in a symphonic concert (the most important benefit) are presented in Table 4.2. 
Table 4.2 Relationship of the core of the concert hall's product with the basic value for the listener

\begin{tabular}{ll}
\hline Core of the product & Most important benefit (basic value) \\
\hline Violin Concerto in A major by M. Karłowicz & Getting to know a masterpiece of Polish music \\
Orchestra - New York Philharmonic & Hearing a renowned symphony orchestra \\
Soloist - Itzhak Perlman & Hearing a prominent violin virtuoso \\
Conductor - James Levine & $\begin{array}{l}\text { Participating in a concert under the guidance of a world- } \\
\text { renowned conductor }\end{array}$ \\
$\begin{array}{ll}\text { Place of performance - Central Park in New York } \\
\text { City }\end{array}$ & In the form of a picnic \\
\hline
\end{tabular}

As shown in Table 4.2, depending on the listener's preferences, the basic value for the consumer of a cultural offer might be not only the opportunity to become acquainted with a specific musical masterpiece, but also, at the same time, to hear an eminent virtuoso playing or taking part in a concert by a renowned symphony orchestra.

Added value is, however, associated with additional services and the process of interaction. It is a set of characteristics and conditions which are expected by customers who decide to buy a particular product. Customers can expect the possibility to book tickets over the phone or via the Internet from a cultural institution. They can expect various forms of payment for tickets, the availability of parking spaces near the building, functioning airconditioning in the concert hall, etc. Of course, as in the case of basic value, the consumers' expectations can also be very different in this respect. For example, in the opera, theater, or concert hall, for some listeners a decisive factor may be the acoustics of the concert hall, while for others more important is the availability of parking near the institution. The main advantage and its associated additional services (added value), delivered in a sequence of episodes within the interaction process, shape the value perceived by the consumer.

When the customer decides to purchase a ticket for a certain artistic event (accepts the value offered by a cultural institution), we move to the main phase of the process of relationship marketing - a bond is established between the cultural institution and the client. Ballantye (1999) draws attention to the role of dialogue in maintaining relationships. Satisfactory contacts between the institution and the consumers of a cultural offer result in 
increasing customer confidence, their attachment to the institute and the gradually climb to the top of the "loyalty ladder" (Figure 4.2). A necessary condition for deepening the relationship is offering value once again to these specific customers (Grönroos 2004). For example, some cultural entities (opera, theaters, museums, concert halls), in seeking to strengthen ties with their customers, invite them to fan clubs, offer special passes (subscriptions) at very attractive prices, or send special newsletters via the Internet from which customers can get information about the cultural institution or the artistic season. In addition, information is sent by mail about the current repertoire, and the most devoted customers are invited to open rehearsals, meetings with artists, and special balls held at the cultural institution (e.g. the opera, concert hall, theater) where they can meet renowned artists, for example.

\section{Developing relationships with donors}

As in the case of consumers of the artistic offer, the process of shaping the relationship between cultural institutions and donors (patrons, sponsors) must start with their segmentation. A donor, patron, or sponsor (generally a donor) are concepts which emerged as early as in Classical times and which still exist in modern dictionaries. Their application relates to similar areas, but the specific meaning has changed. Nowadays, sponsoring is a term which describes the nature and purpose of activities which support various areas of life in order to achieve one's own benefits, and this distinguishes it from patronage or charity the domain of philanthropists (Figure 4.3).

Biegluk points out the differences between charity, sponsorship, and patronage. According to him, charity can be described with the words "I give so you'll have", sponsorship as "I give, so you give", and patronage as "I give so you'll exist" (Grzegorczyk 2003: 47). 




Figure 4.3 Types of donors of cultural institutions

From the very beginning, donors have been connected with cultural institutions. One example is New York's Lincoln Center with the famous Metropolitan Opera. In 1966, architect W.K. Harrison and acoustician C. Harris built the new Metropolitan Opera (MET) as part of the Lincoln Center, which also includes the New York City Ballet and the Avery Fisher Hall. Maintained in its traditional red, white, and gold colors, the Metropolitan Opera has the shape of a five-story horseshoe with rows of boxes on the sides. This arrangement takes into account the will of the donors, who, in contrast to the state-subsidized European stages, financed the entire project and did not want to give up their reserved boxes. These days the Lincoln Center also benefits from the generosity of its donors, who maintain such respected arts organizations as the Metropolitan Opera, New York City Ballet, and New York Philharmonic. Each of these organizations has hundreds of donors who give from several dozen to more than two million dollars a year. Therefore, it is in the interest of this organization to maintain the greatest possible number of loyal sponsors, especially corporate sponsors (businesses, corporations, foundations, etc.), as it is they who transfer the greatest amounts to the New York Lincoln Center. Without these funds, artistic events like the free 
concerts of the MET or the New York Philharmonic in urban parks, as well as numerous educational projects designed for children, would not be possible.

The Metropolitan Opera in New York has divided its donors into two main groups individual donors and corporate donors. The first group is made up of as many as 22 sections which define the level of involvement in the financing of the opera (Table 4.3), whereas the group of corporate donors is made up of nine sections (Table 4.4).

Table 4.3 Guild Member benefits by tier

\begin{tabular}{|c|c|c|}
\hline Patron level & $\begin{array}{l}\text { Donation } \\
\text { (in USD) }\end{array}$ & Benefits \\
\hline $\begin{array}{l}\text { Guild } \\
\text { National } \\
\text { Member }\end{array}$ & from 85 & $\begin{array}{l}\text { A one year subscription to Opera News } \\
\text { Special publications including the Live in } H D \text { and Radio Guide } \\
\text { Discounts at the Met Opera Shop and online store } \\
\text { Discounts on Guild Community Programs } \\
\text { Guild Travel Program }\end{array}$ \\
\hline $\begin{array}{l}\text { Guild } \\
\text { Supporting } \\
\text { Member }\end{array}$ & from 150 & $\begin{array}{l}\text { A one year subscription to Opera News } \\
\text { Guild Travel Program } \\
\text { Special publications including the Live in HD and Radio Guide } \\
\text { Discounts on Guild Community Programs } \\
\text { Met ticket priority by level and periodic ticket discounts } \\
\text { Advance access to tickets for Live in HD cinema presentations in the U.S. and } \\
\text { Canada } \\
\text { Online access to select radio broadcasts, MetTalks panel discussions on new } \\
\text { productions, and more } \\
\text { Discounts at the Met Opera Shop and online store } \\
\text { Notification of Guild Annual Luncheon } \\
\text { Access to National Desk weekend ticket packages for out-of-town members }\end{array}$ \\
\hline $\begin{array}{l}\text { Guild } \\
\text { Contributing } \\
\text { Member }\end{array}$ & from 250 & $\begin{array}{l}\text { Notification of Guild Annual Luncheon } \\
\text { Guild Travel Program } \\
\text { Access to National Desk weekend ticket packages for out-of-town members } \\
\text { Special publications including the Live in HD and Radio Guide } \\
\text { Met ticket priority by level and periodic ticket discounts } \\
\text { Gold Card privileges at hotels, restaurants, retailers, and more } \\
\text { Advance access to tickets for Live in HD cinema presentations in the U.S. and } \\
\text { Canada } \\
\text { A one year subscription to Opera News } \\
\text { Online access to select radio broadcasts, MetTalks panel discussions on new } \\
\text { productions, and more } \\
\text { Discounts at the Met Opera Shop and online store } \\
\text { Discounts on Guild Community Programs }\end{array}$ \\
\hline $\begin{array}{l}\text { Guild Donor } \\
\text { Member }\end{array}$ & from 500 & $\begin{array}{l}\text { Met ticket priority by level and periodic ticket discounts } \\
\text { Notification of Guild Annual Luncheon } \\
\text { Guild Travel Program } \\
\text { Access to National Desk weekend ticket packages for out-of-town members } \\
\text { Special publications including the Live in HD and Radio Guide }\end{array}$ \\
\hline
\end{tabular}




\begin{tabular}{|c|c|c|}
\hline & & $\begin{array}{l}\text { Discounts on Guild Community Programs } \\
\text { Access to the Belmont Room members' lounge } \\
\text { A one year subscription to Opera News } \\
\text { Gold Card privileges at hotels, restaurants, retailers, and more } \\
\text { Advance access to tickets for Live in HD cinema presentations in the U.S. and } \\
\text { Canada } \\
\text { Online access to select radio broadcasts, MetTalks panel discussions on new } \\
\text { productions, and more } \\
\text { Discounts at the Met Opera Shop and online store }\end{array}$ \\
\hline $\begin{array}{l}\text { Guild } \\
\text { Sponsor } \\
\text { Member }\end{array}$ & from 850 & $\begin{array}{l}\text { Met ticket priority by level and periodic ticket discounts } \\
\text { Gold Card privileges at hotels, restaurants, retailers, and more } \\
\text { Guild Travel Program } \\
\text { Access to National Desk weekend ticket packages for out-of-town members } \\
\text { Notification of Guild Annual Luncheon } \\
\text { Two passes to dress rehearsals } \\
\text { Access to the Belmont Room members' lounge } \\
\text { Two guest passes to the Belmont Room } \\
\text { The Met Season Book } \\
\text { A one year subscription to Opera News } \\
\text { Advance access to tickets for Live in HD cinema presentations in the U.S. and } \\
\text { Canada } \\
\text { Online access to select radio broadcasts, MetTalks panel discussions on new } \\
\text { productions, and more } \\
\text { Discounts at the Met Opera Shop and online store } \\
\text { Discounts on Guild Community Programs }\end{array}$ \\
\hline $\begin{array}{l}\text { Guild } \\
\text { Fellow } \\
\text { Member }\end{array}$ & from 1,500 & $\begin{array}{l}\text { Met ticket priority by level and periodic ticket discounts } \\
\text { Access to the Belmont Room members' lounge } \\
\text { The Met Season Book } \\
\text { Gold Card privileges at hotels, restaurants, retailers, and more } \\
\text { Guild Travel Program } \\
\text { Access to National Desk weekend ticket packages for out-of-town members } \\
\text { Notification of Guild Annual Luncheon } \\
\text { Two passes to dress rehearsals } \\
\text { Additional passes to dress rehearsals } \\
\text { Two guest passes to the Belmont Room } \\
\text { A one year subscription to Opera News } \\
\text { Advance access to tickets for Live in HD cinema presentations in the U.S. and } \\
\text { Canada } \\
\text { Online access to select radio broadcasts, MetTalks panel discussions on new } \\
\text { productions, and more } \\
\text { Discounts at the Met Opera Shop and online store } \\
\text { Discounts on Guild Community Programs }\end{array}$ \\
\hline
\end{tabular}




\begin{tabular}{|c|c|c|}
\hline $\begin{array}{l}\text { Guild } \\
\text { Benefactor } \\
\text { Member }\end{array}$ & from 2,000 & $\begin{array}{l}\text { Additional passes to dress rehearsals } \\
\text { Access to the Belmont Room members' lounge } \\
\text { The Met Season Book } \\
\text { Gold Card privileges at hotels, restaurants, retailers, and more } \\
\text { Guild Travel Program } \\
\text { Access to National Desk weekend ticket packages for out-of-town members } \\
\text { Notification of Guild Annual Luncheon } \\
\text { Discounts on Guild Community Programs } \\
\text { Met ticket priority by level and periodic ticket discounts } \\
\text { Two passes to dress rehearsals } \\
\text { Highest level of Guild ticket priority } \\
\text { Two guest passes to the Belmont Room } \\
\text { A one year subscription to Opera News } \\
\text { Advance access to tickets for Live in HD cinema presentations in the U.S. and } \\
\text { Canada } \\
\text { Online access to select radio broadcasts, MetTalks panel discussions on new } \\
\text { productions, and more } \\
\text { Discounts at the Met Opera Shop and online store }\end{array}$ \\
\hline Patron & from 2,750 & $\begin{array}{l}\text { Exclusive dress rehearsals } \\
\text { Patron Lounge and Belmont Room access } \\
\text { VIP Ticket Priority and Personalized Ticket Service } \\
\text { Advance access to single tickets and preferred seating } \\
\text { Complimentary coat check } \\
\text { Young Artist Recitals } \\
\text { MetTalks new production panel discussions } \\
\text { A one year subscription to Opera News } \\
\text { Online access to select radio broadcasts, MetTalks panel discussions on new } \\
\text { productions, and more }\end{array}$ \\
\hline $\begin{array}{l}\text { Contributing } \\
\text { Patron }\end{array}$ & from 3,750 & $\begin{array}{l}\text { VIP Ticket Priority and Personalized Ticket Service } \\
\text { Exclusive dress rehearsals } \\
\text { Patron Lounge and Belmont Room access } \\
\text { Complimentary coat check } \\
\text { Young Artist Recitals } \\
\text { MetTalks new production panel discussions } \\
\text { Advance access to single tickets and preferred seating } \\
\text { Complimentary Backstage Tour } \\
\text { A one year subscription to Opera News } \\
\text { Online access to select radio broadcasts, MetTalks panel discussions on new } \\
\text { productions, and more }\end{array}$ \\
\hline $\begin{array}{l}\text { Sponsor } \\
\text { Patron }\end{array}$ & from 5,500 & $\begin{array}{l}\text { VIP Ticket Priority and Personalized Ticket Service } \\
\text { Patron Lounge and Belmont Room access } \\
\text { Complimentary Backstage Tour } \\
\text { Complimentary coat check } \\
\text { Young Artist Recitals } \\
\text { MetTalks new production panel discussions } \\
\text { Advance access to single tickets and preferred seating } \\
\text { Invitations to select Working Rehearsals } \\
\text { Recognition in Playbill and the Season Book } \\
\text { Additional passes to Dress Rehearsals } \\
\text { A one year subscription to Opera News } \\
\text { Online access to select radio broadcasts, MetTalks panel discussions on new } \\
\text { productions, and more }\end{array}$ \\
\hline
\end{tabular}


Sponsor

Patron with

Production

Fund Gift

Benefactor

Patron

Benefactor

Patron from 6,500 VIP Ticket Priority and Personalized Ticket Service

Invitations to select Working Rehearsals

Recognition in Playbill and the Season Book

Additional passes to Dress Rehearsals

Complimentary Backstage Tour

Complimentary coat check

Young Artist Recitals

MetTalks new production panel discussions

Advance access to single tickets and preferred seating

Season Preview with General Manager Peter Gelb

Patron Lounge and Belmont Room access

A one year subscription to Opera News

Online access to select radio broadcasts, MetTalks panel discussions on new productions, and more

from 7,500 VIP Ticket Priority and Personalized Ticket Service

Recognition in Playbill and the Season Book

Complimentary Backstage Tour

Additional passes to Dress Rehearsals

Complimentary coat check

MetTalks new production panel discussions

Advance access to single tickets and preferred seating

Young Artists Concert

Invitations to select Working Rehearsals

Season Preview with General Manager Peter Gelb

A one year subscription to Opera News

Online access to select radio broadcasts, MetTalks panel discussions on new productions, and more

from 8,500 VIP Ticket Priority and Personalized Ticket Service

Recognition in Playbill and the Season Book

Young Artists Concert

Season Preview with General Manager Peter Gelb

Complimentary Backstage Tour

Complimentary coat check

MetTalks new production panel discussions

Advance access to single tickets and preferred seating

Presentation: The Met: 50 Years at Lincoln Center

Invitations to select Working Rehearsals

A one year subscription to Opera News

Online access to select radio broadcasts, MetTalks panel discussions on new productions, and more 


\begin{tabular}{|c|c|c|}
\hline $\begin{array}{l}\text { Premiere } \\
\text { Circle } \\
\text { Sponsor }\end{array}$ & $\begin{array}{l}\text { from } \\
10,000\end{array}$ & $\begin{array}{l}\text { VIP Ticket Priority and Personalized Ticket Service } \\
\text { Invitations to select Working Rehearsals } \\
\text { Recognition in Playbill and the Season Book } \\
\text { Young Artists Concert } \\
\text { Season Preview with General Manager Peter Gelb } \\
\text { Complimentary Backstage Tour } \\
\text { Presentation: The Met: } 50 \text { Years at Lincoln Center } \\
\text { MetTalks new production panel discussions } \\
\text { Complimentary coat check } \\
\text { Advance access to single tickets and preferred seating } \\
\text { Invitation to Observe a Master Class } \\
\text { A one year subscription to Opera News } \\
\text { Online access to select radio broadcasts, MetTalks panel discussions on new } \\
\text { productions, and more }\end{array}$ \\
\hline $\begin{array}{l}\text { Premiere } \\
\text { Circle } \\
\text { Sponsor }\end{array}$ & $\begin{array}{l}\text { from } \\
12,500\end{array}$ & $\begin{array}{l}\text { VIP Ticket Priority and Personalized Ticket Service } \\
\text { Recognition in Playbill and the Season Book } \\
\text { Invitation to Observe a Master Class } \\
\text { Young Artists Concert } \\
\text { Season Preview with General Manager Peter Gelb } \\
\text { Complimentary Backstage Tour } \\
\text { Presentation: The Met: } 50 \text { Years at Lincoln Center } \\
\text { MetTalks new production panel discussions } \\
\text { Complimentary coat check } \\
\text { Advance access to single tickets and preferred seating } \\
\text { Presentation: Creating a Character } \\
\text { Invitations to select Working Rehearsals } \\
\text { A one year subscription to Opera News } \\
\text { Online access to select radio broadcasts, MetTalks panel discussions on new } \\
\text { productions, and more }\end{array}$ \\
\hline $\begin{array}{l}\text { Premiere } \\
\text { Circle } \\
\text { Benefactor }\end{array}$ & $\begin{array}{l}\text { from } \\
15,000\end{array}$ & $\begin{array}{l}\text { VIP Ticket Priority and Personalized Ticket Service } \\
\text { Presentation: Creating a Character } \\
\text { Recognition in Playbill and the Season Book } \\
\text { Invitation to Observe a Master Class } \\
\text { Young Artists Concert } \\
\text { MetTalks new production panel discussions } \\
\text { Complimentary Backstage Tour } \\
\text { Season Preview with General Manager Peter Gelb } \\
\text { Presentation: The Met: } 50 \text { Years at Lincoln Center } \\
\text { Complimentary coat check } \\
\text { Advance access to single tickets and preferred seating } \\
\text { Invitations to select Working Rehearsals } \\
\text { Invitation to the Metropolitan Opera National Council Semifinals Competition } \\
\text { A one year subscription to Opera News } \\
\text { Online access to select radio broadcasts, MetTalks panel discussions on new } \\
\text { productions, and more }\end{array}$ \\
\hline $\begin{array}{l}\text { Premiere } \\
\text { Circle } \\
\text { Benefactor }\end{array}$ & $\begin{array}{l}\text { from } \\
20,000\end{array}$ & $\begin{array}{l}\text { VIP Ticket Priority and Personalized Ticket Service } \\
\text { Complimentary coat check } \\
\text { Young Artists Concert } \\
\text { MetTalks new production panel discussions } \\
\text { Complimentary Backstage Tour } \\
\text { Recognition in Playbill and the Season Book } \\
\text { Presentation: The Met: } 50 \text { Years at Lincoln Center }\end{array}$ \\
\hline
\end{tabular}




\begin{tabular}{|c|c|c|}
\hline & & $\begin{array}{l}\text { Season Preview with General Manager Peter Gelb } \\
\text { Invitation to Observe a Master Class } \\
\text { Presentation: Creating a Character } \\
\text { Invitation to the Metropolitan Opera National Council Semifinals Competition } \\
\text { Observe a Private Vocal Coaching } \\
\text { Advance access to single tickets and preferred seating } \\
\text { Invitations to select Working Rehearsals } \\
\text { A one year subscription to Opera News }\end{array}$ \\
\hline $\begin{array}{l}\text { President's } \\
\text { Circle } \\
\text { Sponsor }\end{array}$ & $\begin{array}{l}\text { from } \\
25,000\end{array}$ & $\begin{array}{l}\text { All Benefits of the Met's Patron Program } \\
\text { Exclusive dress rehearsals } \\
\text { Ticket priority for opera and dance } \\
\text { Dedicated staff member } \\
\text { Personalized ticketing assistance and guidance } \\
\text { Invitations to exclusive events and recitals } \\
\text { Priority reservations at the Grand Tier Restaurant } \\
\text { Recognition in Met publications }\end{array}$ \\
\hline $\begin{array}{l}\text { President's } \\
\text { Circle } \\
\text { Fellow }\end{array}$ & $\begin{array}{l}\text { from } \\
35,000\end{array}$ & $\begin{array}{l}\text { All Benefits of the Met's Patron Program } \\
\text { Ticket priority for opera and dance } \\
\text { Dedicated staff member } \\
\text { Personalized ticketing assistance and guidance } \\
\text { Invitations to exclusive events and recitals } \\
\text { Priority reservations at the Grand Tier Restaurant } \\
\text { Recognition in Met publications } \\
\text { Additional Dress rehearsal tickets }\end{array}$ \\
\hline Silver Circle & $\begin{array}{l}\text { from } \\
50,000\end{array}$ & $\begin{array}{l}\text { All Benefits of the Met's Patron Program } \\
\text { Additional Dress rehearsal tickets } \\
\text { Ticket priority for opera and dance } \\
\text { Dedicated staff member } \\
\text { Personalized ticketing assistance and guidance } \\
\text { Invitations to exclusive events and recitals } \\
\text { Recognition in Met publications } \\
\text { Dinner for } 8 \text { at the Grand Tier (details vary at each level) } \\
\text { Exclusive luncheon hosted by a Met singer or conductor }\end{array}$ \\
\hline $\begin{array}{l}\text { Golden } \\
\text { Horseshoe - } \\
\$ 75,000 \text { per } \\
\text { year, or } \\
\$ 225,000 \\
\text { over } 3 \text { years }\end{array}$ & $\begin{array}{l}\text { from } \\
75,000\end{array}$ & $\begin{array}{l}\text { All Benefits of the Met's Patron Program } \\
\text { Additional Dress rehearsal tickets } \\
\text { Ticket priority for opera and dance } \\
\text { Dedicated staff member } \\
\text { Personalized ticketing assistance and guidance } \\
\text { Invitations to exclusive events and recitals } \\
\text { Dinner for eight at the Grand Tier (details vary at each level) } \\
\text { Dedication of a performance in your honor and a Center Parterre box } \\
\text { Access to Final Dress Rehearsals for new productions } \\
\text { Annual Golden Horseshoe Dinner with guest artists } \\
\text { Opportunity to purchase, once during a member's tenure, gold cuff links, } \\
\text { stickpin, or brooch designed by Tiffany \& Co. exclusively for the members of } \\
\text { the Golden Horseshoe } \\
\text { Access to the Metropolitan Opera Club }\end{array}$ \\
\hline
\end{tabular}




\begin{tabular}{lll}
\hline Council & from & All Benefits of the Met's Patron Program \\
Sponsor & Dedicated staff member \\
& Personalized ticketing assistance and guidance \\
& Invitations to exclusive events and recitals \\
& Dinner for 8 at the Grand Tier (details vary at each level) \\
& Access to Final Dress Rehearsals for new productions \\
& Annual Golden Horseshoe Dinner with guest artists \\
& Opportunity to purchase, once during a member's tenure, gold cuff links, \\
& stickpin, or brooch designed by Tiffany \& Co. exclusively for the members of \\
& the Golden Horseshoe \\
& Access to the Metropolitan Opera Club \\
& Additional Dress rehearsal tickets \\
& Concierge service offering highest ticket priority \\
& Dedication of a performance in your honor and a Center Parterre box \\
& Invitation to the annual Council Gala \\
& Opportunities to meet Met artists at cast parties, dinners, closed rehearsals, \\
& and more \\
\hline Source http://www.metopera.org/Support/Join-The-Met/Become-a-Guild-Member/ (accessed 21 Sep 2016)
\end{tabular}

Table 4.4 Corporate patron benefits by level

\begin{tabular}{|c|c|c|}
\hline $\begin{array}{l}\text { Corporate } \\
\text { patron } \\
\text { level }\end{array}$ & $\begin{array}{l}\text { Donation } \\
\text { (in USD) }\end{array}$ & Benefits \\
\hline $\begin{array}{l}\text { Corporate } \\
\text { Patron }\end{array}$ & 2,750 & Patron Lounge access \\
\hline $\begin{array}{l}\text { Sponsor } \\
\text { Patron }\end{array}$ & 5,500 & $\begin{array}{l}\text { All of the benefits above, plus: } \\
\text { Recognition in Playbill, the Season Book, and Annual Report } \\
\text { Additional dress rehearsal passes (increases with each level) } \\
\text { Employee discounts at the Met Opera Shop }\end{array}$ \\
\hline $\begin{array}{l}\text { Premiere } \\
\text { Circle } \\
\text { Sponsor }\end{array}$ & 10,000 & $\begin{array}{l}\text { All of the benefits above, plus: } \\
\text { Employee Discount Ticket Program - up to } 65 \% \text { off } \\
\text { Executive benefits, including concierge service, for } 2 \text { executives }\end{array}$ \\
\hline $\begin{array}{l}\text { Premiere } \\
\text { Circle } \\
\text { Benefactor }\end{array}$ & 15,000 & $\begin{array}{l}\text { All of the benefits above, plus: } \\
\text { Private Group Tour }\end{array}$ \\
\hline $\begin{array}{l}\text { President's } \\
\text { Circle } \\
\text { Sponsor }\end{array}$ & 25,000 & $\begin{array}{l}\text { All of the benefits above, plus: } \\
\text { Opportunity to host a lecture with light reception at the Opera House }\end{array}$ \\
\hline
\end{tabular}




\begin{tabular}{|c|c|c|}
\hline $\begin{array}{l}\text { President's } \\
\text { Circle } \\
\text { Fellow }\end{array}$ & 35,000 & $\begin{array}{l}\text { All of the benefits above, plus: } \\
\text { Opportunity to host one cocktail event at the Opera House } \\
\text { Dress rehearsal sponsorship opportunity (available for this level only) }\end{array}$ \\
\hline $\begin{array}{l}\text { Silver } \\
\text { Circle }\end{array}$ & 50,000 & $\begin{array}{l}\text { All of the benefits above, plus: } \\
\text { Executive benefits, including concierge service, for } 3 \text { executives } \\
\text { Opportunity to host one cocktail OR one dinner event at the Opera House } \\
\text { Opportunity to invite a Lindemann Young Artist to perform at an event }\end{array}$ \\
\hline $\begin{array}{l}\text { Golden } \\
\text { Horseshoe }\end{array}$ & 75,000 & $\begin{array}{l}\text { All of the benefits above, plus: } \\
\text { Opportunity to host one cocktail AND one dinner at the Opera House }\end{array}$ \\
\hline $\begin{array}{l}\text { Corporate } \\
\text { Council } \\
\text { Sponsor }\end{array}$ & 100,000 & $\begin{array}{l}\text { All of the benefits above, plus: } \\
\text { Executive benefits, including concierge service, for } 4 \text { executives } \\
\text { Dedication of } 3 \text { performance days } \\
\text { Prominent corporate visibility in the Opera House during dedication days } \\
\text { Client entertaining opportunities } \\
\text { Opportunity to host a range of events at the Opera House }\end{array}$ \\
\hline
\end{tabular}

Source http://www.metopera.org/Support/Corporate-Partnership/Corporate-Partnership/ (accessed 21 Sep 2016)

Such a precise breakdown of individual and corporate donors required the preparation of a separate offer for each group which would not be possible without regular market research (Kolb 2005). In the case of the sponsors of cultural institutions, the basic parameters of the companies which are sought as sponsors must first be determined. Standard criteria which are taken into consideration in this type of analysis are the location and geographic coverage, turnover and the level of promotional spending, the standard duration of promotional campaigns and their cyclical nature, the expected way of receiving benefits by the sponsor (in kind, service, financial), and the nature of promotion objectives. From the point of view of the potential effectiveness of acquiring sponsors the characteristics of the target group of the sponsoring company should be determined. The geographical strategy for the selection of sponsors can be based on many observations of their activities. Often, supporting cultural development in the region is the main incentive for sponsors to make a decision about sponsoring (Grzegorczyk 2003: 202). Permanent sponsors of the Polish Baltic Philharmonic in Gdansk are, for example, the EDF Group or the Energa Group (large power companies), which are based in Gdansk.

In the case of the patrons and donors of cultural institutions, the basic value is prestige in itself, the satisfaction of belonging to a group of philanthropists. This value satisfies the 
need for respect and recognition. A cultural institution, in order to establish a long-term relationship with this specific group of donors, also offers added value. For example, the National Philharmonic in Warsaw gives its donors and patrons membership to the National Philharmonic Friends Club, which enables the wider involvement in the activities of the concert hall (Table 4.5).

Table 4.5 Additional benefits offered to selected consumers of the cultural offer of the National Philharmonic in Warsaw

\begin{tabular}{|c|c|c|c|}
\hline Card type & $\begin{array}{l}\text { Amount } \\
\text { of } \\
\text { support } \\
\text { in PLN }\end{array}$ & $\begin{array}{l}\text { Benefits offered by the National Philharmonic (NP) in Warsaw } \\
\text { to Club Members }\end{array}$ & 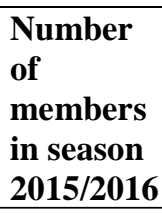 \\
\hline $\begin{array}{l}\text { Bronze } \\
\text { Card }\end{array}$ & $\begin{array}{l}\text { From } \\
100\end{array}$ & $\begin{array}{l}\text { The right to: } \\
\text { Receive information about NP's repertoire in the selected manner } \\
\text { (mail, e-mail), } \\
\text { Take advantage of a special pool of reserved tickets which expire } \\
30 \text { days before the concert, } \\
\text { Participate in Thursday rehearsals, } \\
\text { Have their name - if the person does not object - included on the list } \\
\text { of Club Members in the NP's programs published once a month, on } \\
\text { the NP's website and in the annual program book. }\end{array}$ & 21 \\
\hline Silver Card & $\begin{array}{l}\text { From } \\
500\end{array}$ & $\begin{array}{l}\text { The right to: } \\
\text { Receive information about NP's repertoire in the selected manner } \\
\text { (mail, e-mail), } \\
\text { Participate in Thursday orchestra rehearsals, } \\
\text { Have their name - if the person does not object - included on the list } \\
\text { of Club Members in the NP's programs published once a month, on } \\
\text { the NP's website and in the annual program book, } \\
\text { Receive a free program during NP concerts, } \\
\text { Take advantage of a special pool of reserved tickets which expire } \\
15 \text { days before the concert, } \\
\text { Receive a free Program Book for the artistic season, } \\
\text { Participate in meetings organized for Club Members. }\end{array}$ & 8 \\
\hline Gold Card & $\begin{array}{l}\text { From } \\
1000\end{array}$ & $\begin{array}{l}\text { The right to: } \\
\text { Receive information about NP's repertoire in the selected manner, } \\
\text { Participate in Thursday orchestra rehearsals, } \\
\text { Have their name - if the person does not object - included on the list } \\
\text { of Club Members in the NP's programs published once a month, on } \\
\text { the NP's website and in the annual program book, } \\
\text { Receive a free program during NP concerts, } \\
\text { Receive a free program book for the artistic season, } \\
\text { Participate in meetings organized for Club Members, } \\
\text { Receive NP's publications, } \\
\text { Participate with a companion in meetings organized in the } \\
\text { Government Room during concert intermissions, } \\
\text { Participate in meetings with artists organized by the NP, } \\
\text { Take advantage of a special pool of tickets (two tickets), which } \\
\text { expires } 1 \text { day before the concert. }\end{array}$ & 35 \\
\hline
\end{tabular}






The members of this club participate in, among other things, open rehearsals, which gives them the opportunity to lead an interesting social life. Every year there are Christmas parties and meetings to celebrate the end of the artistic season, where the club members (Gold and Platinum Cards) can meet with the conductor of the orchestra, soloists, musicians, as well as personalities of the world of culture. Such events are very prestigious. 
The Polish Baltic Philharmonic in Gdansk, in order to establish long-term relationships, offered so-called "Music Lover's Seats" to its patrons and donors. These seats feature a special plaque with the donor's name. The donor receives an additional pass - a subscription, with a certificate and an ID card, with which he can participate in all artistic events branded by the Polish Baltic Philharmonic.

A perfect example of an institution that has successfully built long-term relationships with its patrons and donors is the New York Philharmonic. Proof of this is the fact that its programs are chock-full with the names of patrons and donors. Donors belonging to the socalled "Leonard Bernstein Circle" in sections "Maestro" and "Concertmaster" are invited to receptions, dinners, and lunches with the biggest stars of the New York Philharmonic, as well as guest stars. Moreover, they can choose one concert a year which will be dedicated to them or can be dedicated to a selected person. This system allows the fulfillment of the snobbish needs of these groups who, dressed in tuxedos, arrive at the concert in Rolls Royces and mingle with people of similar status. Treating selected donors in such a special manner brings valuable income that can be spent, for example, on organizing free concerts in public places, e.g. on the lawn in Central Park.

However, in many cases, just the prestige and satisfaction of belonging to a group of philanthropists is not enough. When a donor wants to receive specific benefits (values) in exchange for their support (financial, material, service), we are dealing with sponsorship. The offer for this type of donors must focus on specific proposals of promotional solutions which are presented to a potential sponsor and these should be individual in nature, taking into account the specificity of the industry and the market conditions of the sponsor. The offer must convince the potential sponsor that, for his money, he is given the opportunity to have a more effective impact than in the case of other forms of promotion (Farb 2004, Laura and Sally 2000). One group of institutions deeply believing in the sense and importance of sponsoring culture (especially high culture) are banks and insurance companies. They are fully aware that sponsorship is commercial in nature and as such it should appeal to their clients. Banks and insurance companies wish to be associated with the image of an institution which is friendly, serious, and trustworthy. According to the management of Bank Handlowy w Warszawie S.A., this image is obtained by sponsoring concert halls, concerts, opera performances, and recordings of classical music. The authorities of the Bank of 
Scotland agree with this approach and traditionally support two musical groups: the Scottish Chamber Orchestra and the National Youth Orchestra of Scotland (Górzyński 2000: 54). Companies presenting other areas of business also promote cultural institutions. Volvo, as a company which builds its image on the elements of durability, safety, and ecology, has been sponsoring the Gothenberg Philharmonic Orchestra since 1979. It is accepted that there is no contradiction in this, since the orchestra hall adheres to the highest values, like Volvo. It is important, therefore, that cultural institutions make a thorough analysis of the needs or preferences of a potential sponsor, as confusion in this area means that the potential sponsor may receive an unattractive offer, which it will not choose. We must also remember that when obtaining funds, a specific product is being sold. A potential sponsor must know exactly what can be purchased and for how much. For example, the Krakow Philharmonic, in exchange for monetary or in kind contributions, offers the opportunity for sponsors to have their company logo on the façade of the concert hall building, concert posters (more than 800 posters per month with the size of $70 \times 100 \mathrm{~cm}$ ), season programs (5000 copies each season), concert programs (an average of 300 copies per concert), and on the website; as well as the possibility to place company advertising leaflets in the lobby of the concert hall, available before the concert and during the intermission, to display sponsors' advertising spots on LCD screens, direct presentation of the brand during concerts, and the presence of the sponsor in the media during press conferences and other accompanying events. This package is agreed and negotiated individually, depending on the amount transferred to the concert hall.

It is very important that each element of contact, which a cultural institution tries to establish with a potential sponsor, is maintained at a level corresponding, as much as possible, to the competence of such a person in the sponsoring institution. It is also necessary to remember that when a contract is signed the sponsor becomes a client of the cultural institution and should therefore be able to participate and observe, as well as receive evidence that his interests are being well cared for. The range of services provided to the sponsor should go beyond the provisions of the agreement whenever possible (Shani and Chalasani 1992, Grzegorczyk 2003).

At the moment of the decision to transfer funds or make an in-kind contribution, we move on to the main phase of the relationship marketing process - a bond between the 
cultural institution and its donors is established. Satisfactory contacts between the cultural institution and donors result in increasing their confidence, where they may become attached to the institution and gradually climb to the top of the "loyalty ladder". A necessary condition for deepening the relationship is re-offering value to these specific customers. The National Philharmonic, in seeking to strengthen ties with the most generous donors, awards its donors with statuettes of the patron of the year and the sponsor of the year during an annual gala. This form of distinction certainly has a positive impact on the image of the patron or sponsor and, at the same time, motivates those who have been honored to continue their activities and maintain the relationship. The Krakow Philharmonic, in order to deepen its relationships with patrons, donors, and sponsors, sends them invitations to concerts along with the program, offering the especially meritorious ones personal seats in the sponsors' lodge, or awards them, for example, with the "Honorary Badge of the Philharmonic."

However, there are often situations when the value is rejected and the relationship is weakened or broken. It must be remembered that both the needs of the donors and the values offered by cultural institutions are dynamic. For example, this can happen because of fluctuations in the level of the quality of services or the level of the value perceived by the donor. If the distance between the offered and the desired value exceeds a critical point, this is usually followed by the rejection of the offer. Therefore, it is important to constantly monitor the process of relationship marketing and not only the achievement of the objectives of the cultural institution, but also the so-called critical moments, such as the rejection of the value offered by the artistic organization.

\section{Developing relationships with employees}

Another important group of participants in the cultural sector are the employees of cultural institutions, in particular the artists. Just a dozen years ago, a great talent and masterful craftsmanship placed a number of stage artists as if above the laws applicable to people in other professions. Artists often took advantage of these privileges, tyrannizing mercilessly the managing bodies of operas, theaters, concert halls, impresarios, and even other artists 
(Kański 1974: 418, Bing 1982, Kaczyński 1992). When the famous prima donna Maria Malibran allowed herself to replace a whole scene in one opera with a fragment from the work of another composer, the unfortunate author, who was present at the show, dared not even protest. The great Adelina Patti travelled to concerts in a luxury private train with her family, servants, and a large number of her favorite dogs and birds. For her performances she collects staggering fees, and when one of the concert agents dared to mention that not even the President of the United States earned this much, Patti replied imperturbably: "If the president is cheaper then let the president sing" (Kański 1974). Today, the order of things has changed and the living conditions of artists have also changed significantly. Despite the fact that the time has passed when the cultural sector was reigned over by artists like operatic prima donnas, building lasting relationships with key employees is still very important to a cultural institution.

The process of building long-term relationships (Figure 4.1), much as in the case of consumers of the artistic offer or donors, should begin with carrying out a segmentation of the institution's employees. The market success of cultural institutions is often decided by its employees, in particular the artists who often endorse the institution with which they are associated with their name. Every major cultural institution has weak, average, and excellent employees, so it is very important to determine which employees are of the highest value for the organization (Barlow 2006, Bhattacharya et al. 2008, Cheese 2008, Clayton 2007, Garrow and Hirsh 2008, Grzegorczyk and Kopeć 2013, Maxwell and Farquharson 2008, Pocztowski 2008, Ulrich 2008, Zheng et al. 2008, Szczepańska-Woszczyna and KurowskaPysz 2016). Managers of cultural entities do not always dedicate enough time and attention to distinguishing the best employees, and therefore, according to Luecke (2003: 134), they should at least make a list of people who:

- Are formal or informal leaders;

- Continuously achieve excellent results;

- Have practical and valuable ideas;

- Require little or no supervision in the performance of their tasks;

- Facilitate the work of others; 
- Have unique knowledge or skills, the replacement of which would take a lot of time and money;

- Could cause great harm to the cultural institutions, if they would start working for direct competition.

It is also important for managers to identify the most important categories of employees. To do this, the following questions should be answered (Luecke 2003, SzczepańskaWoszczyna et al. 2015):

- Which employees are key to the institution's operations, and at the same time are scarce in the labor market;

- Which employees would cause the greatest confusion if they left;

- Which employees' employment and training cost the most;

- Which employees control the relations of the company with the employees;

- Which employees act as important carriers of information within the company.

In cultural institutions two basic groups of employees can be distinguished: artists and organizational employees. An example of employee segmentation in cultural institutions might look like this:

- Big personalities - this group includes the key artists of the cultural institution. For example, in an opera or a philharmonic, these will include the conductor, soloist singers, soloist instrumentalists, soloist dancers, directors, show set designers, and choreographers;

- Supporting artists - this is another very important group of employees, without who the performance of a particular musical work would not be possible. In relation to the opera and the philharmonic this group includes the orchestra musicians, choir, members of the ballet company, persons responsible for the preparation of the choir, ballet, and other musicians;

- Managers - persons managing the cultural institution, involved in raising funds, entering into contracts with artists, analyzing customer preferences, etc.;

- Administrative staff - office workers of the cultural institution;

- Other employees. 
Following the guidelines presented by Luecke (2003), there is no doubt that the key employees of cultural institutions are the artists, especially the big personalities, whose talent and fame often determine the market success of the cultural institution in the art market. The long-time director of the Metropolitan Opera in New York - Rudolf Bing (1982: 34) argues that working with artists is fundamentally different from working with people of all other professions. In his opinion, the administrative staff also undoubtedly have their own ambitions, but they do not necessarily have to put everything on the line every day and fight for their existence every night. Therefore, artists are exceptional - sensitive and irritable, nervous and somewhat crazy. However, we must not forget about the organizational employees (mostly managers) whose organizational skills and ingenuity often mean that the given artistic project can come to fruition.

As in the case of consumers of the artistic offer or cultural institution donors, in order to establish long-term relationships with key employees, an organization must offer them a certain value (benefit). A set of core benefits sought by artists is presented in Table 4.6.

Table 4.6 Key benefits sought by artists

\begin{tabular}{ll}
\hline Key benefit & Specification \\
\hline Financial benefits & $\begin{array}{l}\text { Satisfactory fees, salaries } \\
\text { Additional bonuses depending on the volume of sales } \\
\text { Company apartment, car, etc. } \\
\text { Covering the costs of travel, accommodation }\end{array}$ \\
& $\begin{array}{l}\text { Opportunity to present themselves on the stage of a prestigious opera house, theater, } \\
\text { concert hall, etc. (at the Teatro alla Scala in Milan or at the Metropolitan Opera in New }\end{array}$ \\
& $\begin{array}{l}\text { York, Carnegie Hall in New York) } \\
\text { The opportunity to work with renowned artists, conductors, directors } \\
\text { The opportunity to work with a renowned artistic team (e.g. with the Vienna } \\
\text { Philharmonic, New York Philharmonic, etc.) } \\
\text { The opportunity to participate in a unique artistic endeavor (e.g. New Year concerts in } \\
\text { Vienna, anniversary concerts, etc.). } \\
\text { Participation in recording sessions, television and radio programs. }\end{array}$ \\
& $\begin{array}{l}\text { The opportunity to work with renowned directors, conductors, artists, etc. } \\
\text { The opportunity of creating a new stage character, act in a new play, opera, discover a } \\
\text { Pew repertoire, etc. }\end{array}$ \\
\hline
\end{tabular}

When on April 10, 1973 Maria Callas took the trouble to put on an opera in the newly rebuilt Teatro Regio in Turin for the first time, the management of the theater, in order to win over the famous prima donna so she would appear in their artistic venture, had to recruit 
artists directly indicated by her, which meant that the music management by the renowned conductor Gianandrea Gavazzeni was even handed over to another great conductor, Vittorio Gui (Kaczyński 1992).

When we manage to hire the artist or manager desired by the cultural institution, we may proceed to the next phase of relationship marketing, the phase of strengthening the bonds. The cultural institution, which wants to retain the most valuable employees and create a strong artistic team, must allocate some funds for the individual professional development of artists and other key employees. It must ensure that the employee always feels that he is constantly learning something and that he is facing challenges posed by new responsibilities. An artist should feel excited about the job, and should not feel that he has stopped in his development, as this could lead to his departure from the institution (Zieliński 2005). Therefore, managers of cultural institutions should (Luecke 2003: 163):

- Create a ladder of professional development for each person they want to retain;

- For people who can be promoted, outline the distance between the skills and experience they already have and what they will need to have in order to move into new roles. Then, they should fill in the gaps using training and suitable tasks;

- "Challenge" talented employees. The cultural institution cannot allow talented people to stagnate professionally;

- Make sure that everyone who needs a suitable mentor has one.

The cultural institution will never be able to retain everyone, and should not try to do so. Some staff turnover (of artists and managers) can actually improve the condition of a cultural institution, by breathing new energy and ideas into it. Yet the turnover of valuable employees is costly, disruptive, and negatively correlated with customer satisfaction. If the employees feel connected with the cultural institution, it is more likely that they will share their positive feelings towards the institution with the clients and this, in turn, will significantly improve its image. 


\section{References}

Ballantye D. (1999), 'Dialogue and Knowledge Generation: Two Sides of the Same Coin in Relationship Marketing', www.meb.co.uk/services/conferen/nov99/rm/paper3.html (accessed 19 Sep 2000)

Barlow L. (2006), 'Talent development: the new imperative?', Development and Learning in Organizations, Vol. 20

Berry L.L. (1995), 'Relationship marketing of services-growing interest, emerging perspectives', Journal of the Academy of Marketing Science, Vol. 23(4)

Bhattacharya C.B., Sen S., Korschun D. (2008), 'Using corporate social responsibility to win the war for talents', MIT Sloan Management Reviev, Vol. 1

Bing R. (1982), 5000 wieczorów w operze, Państwowy Instytut Wydawniczy, Warszawa

Cheese P. (2008), 'Talent: A critical issue facing', The British Journal of Administrative Management, Vol. 2

Claycomb C., Martin C.L. (2013), 'Building customer relationships: an inventory of service providers' objectives and practices', Journal of Services Marketing, Vol. 16(7), pp. 615-635, doi: http://dx.doi.org/10.1108/08876040210447342

Clayton G. (2007), 'Fostering talent opportunity: getting past first-base', Strategic Direction, Vol. 23

Corporate patron benefits by level, http://www.metopera.org/Support/Corporate-Partnership/CorporatePartnership/ (accessed 21 Sep 2016)

Egan J. (2008), Relationship marketing: exploring relational strategies in marketing, Pearson Education, London

Farb C. (2004), The Fine Art of Fundraising, Emmis Books, Cincinnati

Furtak R. (2003), Marketing partnerski na rynku ustug, PWE, Warszawa

Garrow V., Hirsh W. (2008), 'Talent management: Issues of focus and fit', Public Personnel Management, Vol. 37

Górzyński M. (2000), 'Jak to się robi’, Brief, Vol. 4

Grönroos C. (2004), 'The relationship marketing process: communication, interaction, dialogue, value', Journal of Business \& Industrial Marketing, Vol. 19(2), pp. 99-113, doi:

http://dx.doi.org/10.1108/08858620410523981

Grzegorczyk A.M. (2003), Sponsoring kultury, Oficyna Wydawnicza ASPRA-JR, Warszawa

Grzegorczyk A.M., Kopeć T. (2013), Z talentem do gwiazd. Jak robić karierę w show-biznesie, Wydawnictwo Helion, Gliwice

Guild Member benefits by tier, http://www.metopera.org/Support/Join-The-Met/Become-a-Guild-Member/ (accessed 21 Sep 2016)

Ha S., Stoel L. (2008), 'Promoting customer-retailer relationship building: Influence of customer trustworthiness of customer loyalty program marketing', Journal of customer behavior, Vol. 7(3), pp. 215229, doi: http://dx.doi.org/10.1362/147539208X369652 
Hollensen S. (2015), Marketing management: A relationship approach, Pearson Education, London Kaczyński B. (1992), Dzikie orchidee, Orfeo Fundacja im. Bogusława Kaczyńskiego, Warszawa

Kański J. (1974), Mistrzowie sceny operowej, Polskie Wydawnictwo Muzyczne, Warszawa

Kinard B.R., Capella M.L. (2006), 'Relationship marketing: the influence of consumer involvement on perceived service benefits', Journal of Services Marketing, Vol. 20(6), pp. 359-368, doi: http://dx.doi.org/10.1108/08876040610691257

Kolb B.M. (2005), Marketing for Cultural Organizations: New strategies for attracting audiences to Classical Music, Dance, Museums, Theater and Opera, Thomson Learning, London

Laura W., Sally H. (2000), 'Building donor relationships: An investigation into the use of relationship and database marketing by charity fundraisers', The Service Industries Journal, Vol. 20(2), pp. 114-132, doi: http://dx.doi.org/10.1080/02642060000000023

Luecke R. (2003), Jak zatrudnić i zatrzymać najlepszych, Harvard Business Essentials, Wydawnictwo MT Biznes sp. z o. o., Warszawa

Maxwell G., Farquharson L. (2008), 'Senior managers' perceptions of the practice of human resource management', Employee Relations, Vol. 30

Mokwa M.P., Prieve E.A., Dawson W.M. (eds) (1980), Marketing the Arts, Praeger Press, New York

Ndubisi O.N. (2006), 'Effect of gender on customer loyalty: a relationship marketing approach', Marketing intelligence \& planning, Vol. 24(1), pp. 48-61, doi: http://dx.doi.org/10.1108/02634500610641552

Palmatier R.W., Scheer L.K., Houston M.B., Evans K.R., Gopalakrishna S. (2007), 'Use of relationship marketing programs in building customer-salesperson and customer-firm relationships: Differential influences on financial outcomes', International Journal of Research in Marketing, Vol. 24(3), pp. 210-223, doi: http://dx.doi.org/10.1016/j.ijresmar.2006.12.006

Palmatier R.W., Scheer L.K., Evans K.R., Arnold T.J. (2008), ‘Achieving relationship marketing effectiveness in business-to-business exchanges', Journal of the Academy of Marketing Science, Vol. 36(2), pp. 174-190, doi: http://dx.doi.org/10.1007/s11747-007-0078-5

Peck H., Christopher M., Clark M., Payne A. (2013), Relationship marketing, Taylor \& Francis, Oxford Pocztowski A. (ed.) (2008), Zarządzanie talentami w organizacji, Oficyna Wolters Kluwer Polska, Warszawa

Regulations of the National Philharmonic Friends Club, http://filharmonia.pl/sponsorzy-i-partnerzy/klubprzyjaciol-filharmonii-narodowej/regulamin-klubu-przyjaciol-filharmonii-narodowej/ (accessed 21 Sep 2016)

Sargeant A. (2004), Marketing w organizacjach nonprofit, Oficyna Ekonomiczna, Kraków

Shani D., Chalasani S. (1992), 'Exploiting Niches Using Relationship Marketing', Journal of Consumer Marketing, Vol. 9(3), pp. 33 - 42, doi: http://dx.doi.org/10.1108/EUM0000000002532

Sobocińska M. (2015), Uwarunkowania i perspektywy rozwoju orientacji rynkowej w podmiotach sfery kultury. Wydawnictwo Uniwersytetu Ekonomicznego we Wrocławiu, Wrocław

Szczepańska-Woszczyna K., Kurowska-Pysz J. (2016), 'Sustainable business development through leadership in SMEs', Economics and Management, Vol. 8(3), pp. 57-69, doi: 10.1515/emj-2016-0024 
Szczepańska-Woszczyna K., Dacko-Pikiewicz Z., Lis M. (2015), 'Responsible leadership: a real need or transient curiosity', Procedia - Social and Behavioral Sciences, 213, pp. 546-551

Ulrich D. (2008), 'Call for talent: What is the best solution?', Leadership Excellence, Vol. 25

Wróblewski Ł. (2012), Strategie marketingowe w instytucjach kultury, PWE, Warszawa

Zheng C., Soosay C., Hyland P. (2008), 'Manufacturing to Asia: who will win the emerging battle for talent between Dragons and Tigers?', Journal of Manufacturing Technology Management, Vol. 19

Zieliński B. (2005), 'Zarządzanie zasobami ludzkimi’, Oficyna Ekonomiczna, Kraków 


\section{Chapter 5}

\section{New media and technology in the strategic activities of cultural organizations}

\section{Websites in the marketing activities of cultural organizations}

With the development of the Internet, not only is the number of users is increasing, but the range of solutions offered is also becoming wider. Websites set up by cultural institutions or companies in the cultural industries are often the first element which a potential customer encounters (a buyer of goods and services, a member of an organization, a volunteer, or a donor). Therefore, full use of this particular tool in the marketing activities of cultural organizations is very important. The main reasons for the active use of websites by the entities in the cultural sector are:

- Global impact, i.e. the possibility of reaching many millions of people around the world;

- Multimedia character - the ability to transmit information in the form of text, sound, or a short video;

- No limits on time and advertising space;

- Flexibility of action - ability to constantly modify websites;

- Interactivity - two-way communication between the organization and various interested parties;

- Low cost of communication - much lower costs to create one's own website than, for example, producing and broadcasting an advertising spot on television (Wierenko 2005: 685); 
- Functional and up-to-date website - nothing has such a negative effect on the perception of a modern organization as presenting out-dated content on the Web. The Internet is a medium that is primarily supposed to overtake other channels in providing up-to-date information;

- Optimization of the website in leading search engines - if you can't find something on the Internet, it probably doesn't exist at all, as they say in America. Entities in the cultural sector, which have a website that no one can find, are not only not building their image but are in fact ruining it;

- The opportunity to receive a newsletter, i.e. information sent out regularly by e-mail with news relating to the organization - not only allows the organization to keep in touch with the consumer, but, by providing interesting information about new products or services, allows the shaping of the organization's image (Nogieć 2005: 671, Carr 2005, Le et al. 2016).

The active use of the Internet in the culture sector is also supported by the results of research conducted among customers and potential customers of the offer of cultural institutions in Euroregion Śląsk Cieszyński. $71.1 \%$ of respondents declared that they get information about the cultural institutions' offers from the Internet (Figure 5.1).



Figure 5.1 Method of obtaining information by respondents about the cultural institutions' offer in Euroregion Śląsk Cieszyński. Source Wróblewski (2016: 204) 
A well prepared website can have a very beneficial effect on the functioning of entities in the cultural sector. According to the surveys, it enables:

- The shaping of the image of the organization;

- A dialogue with interested parties (consumers of goods and services, donors, members, employees, volunteers, etc.);

- The better promotion of events organized by the entity in the cultural sector, thus increasing the demand for them;

- Educating internal and external interested parties;

- Greater public support for the functioning of this type of entity;

- The acquisition of donors (patrons and sponsors);

- The establishing of professional cooperation between the organization in the cultural sector and its interested parties.

In organizations in the cultural sector, websites are opening up new communication channels (e.g. Facebook profile, YouTube channel, blog, online shop), which often give them direct access to consumers and opinion-forming centers. It should be noted, however, that a well-designed website with a profile, e.g. on Facebook, is something more than just a communication tool. It allows for a new mode of action, which requires different information flows. These, in turn, have an impact not only on communication, but also form new distribution channels and have an overall impact on the shape of the entire marketing mix (Lupa 2014: 94). The Internet also creates good opportunities for advertising by operators in the cultural sector. It is possible to advertise events in the area of culture and products offered by companies in cultural industries, both at the headquarters of the organization, as well as on the website, e.g. in an online shop (Figure 5.2). 

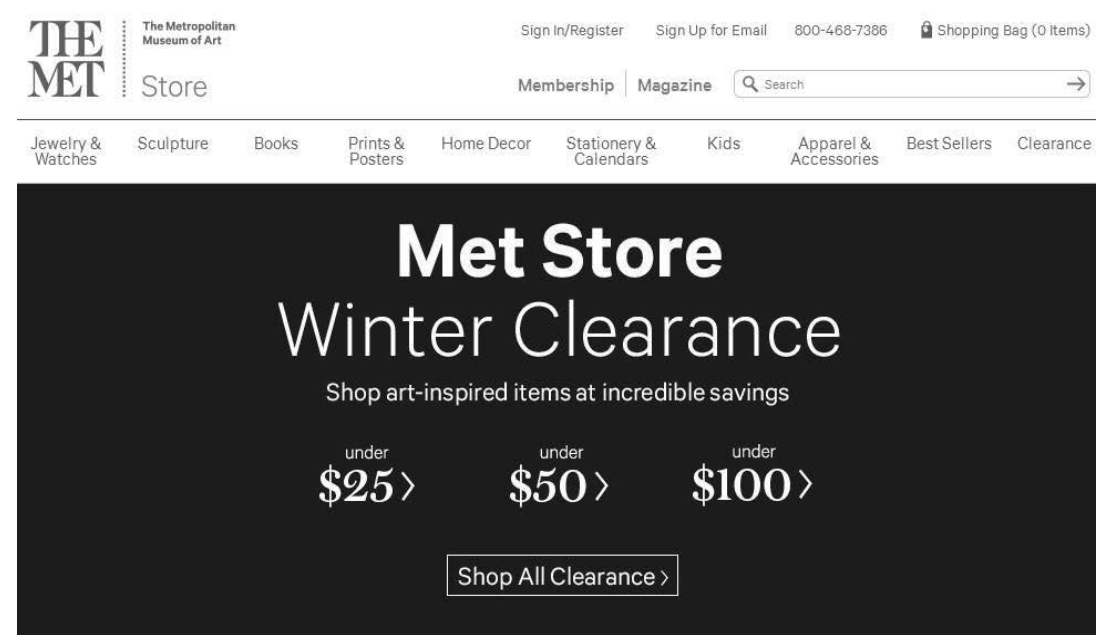

Figure 5.2 Online shop of the Metropolitan Museum of Art in New York.

Source http://store.metmuseum.org/bracelets/tibetan-dragon-cuff/invt/09064411 (accessed 20 Aug 2016)

As a result of twenty-first century market demands in the cultural sector, it has become almost necessary to use online systems for the reservation and purchase of tickets (Figure 5.3). These systems are designed to increase the volume of sales, as well as reduce the costs associated with sales. In their databases, online reservation systems collect data on the organizers of exhibitions, concerts, theatrical and opera performances, film screenings, and other entities in the cultural sector. Thus the customer can choose a cultural event from a variety of offers presented in a uniform manner, often on a single website. The use of such online systems makes it possible to reserve and purchase tickets at any time and from any location, eliminating the need to personally visit the institution at a specific time. In addition, the systems send notifications by e-mail or text message (Carr 2004). These systems, in addition to improved customer service, enable the use of reporting functions, e.g. concerning the popularity of certain products offered by cultural institutions. 


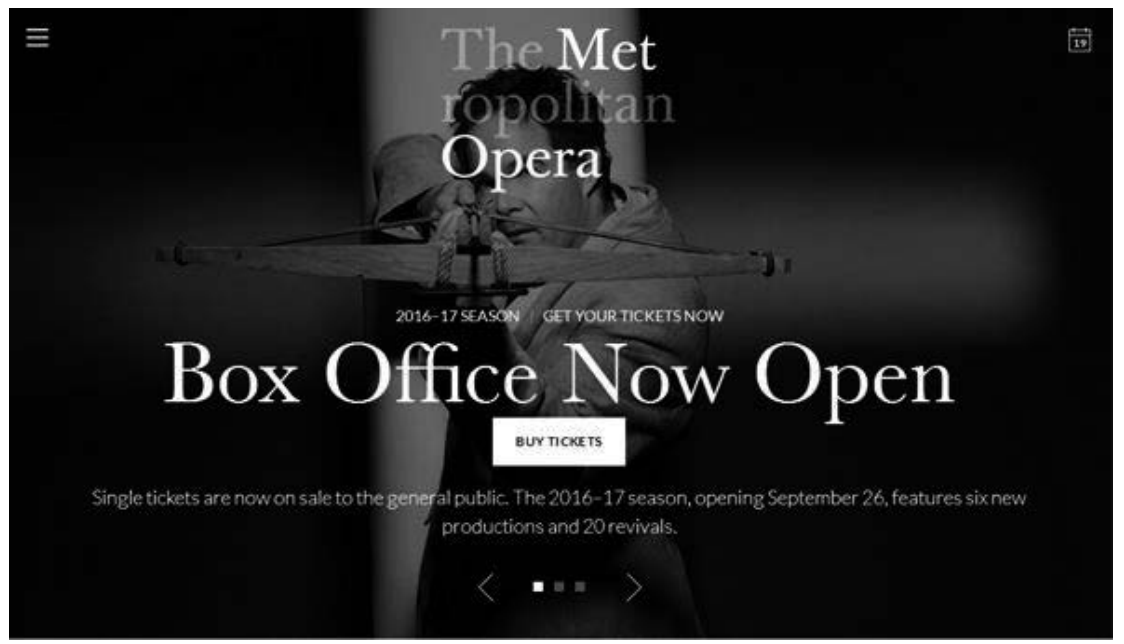

Figure 5.3 A screenshot of the online shop of The Metropolitan Opera.

Source http://www.metopera.org/ (accessed 20 Aug 2016)

Websites have become a very effective tool in building an organization during its learning process, among other things by providing often ready-made solutions to improve the operation of the organization, the implementation of innovative ideas shaping the product offered by the organization in the cultural sector, and finally by providing new knowledge about the environment of the organization as part of public relations activities, including the development of relations with journalists. Activities aimed at building good relationships with the media very often take the form of a subpage performing the function of an online press office (Figure 5.4). 


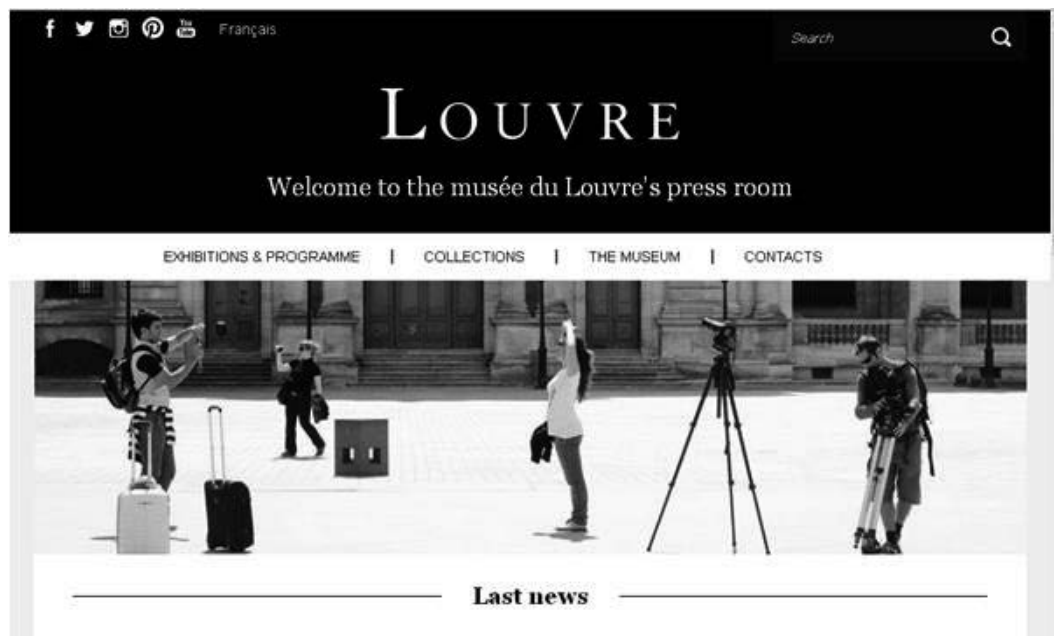

Figure 5.4 Virtual press office of the Louvre Museum in Paris.

Source http://presse.louvre.fr/en/ (accessed 20 Aug 2016)

Communication which uses the Internet provides a wide flow of information and the possibility of communicating with customers or other organizations, also developing their flexibility (Gargiulo and Benassi 2000: 194). A look at the organization and its existing problems from different points of view develops thought processes and improves creativity and the quality of problem solving (Nemeth 1997: 55-59). Educational projects can be an example of communication on the Internet between cultural entities and the youngest consumers of the cultural offer. These are mostly special educational subpages for children which, in a very attractive way - through games, or short animated films - educate and present the cultural institution and its products, literally "pulling in" the young to the world of opera, theater, a concert hall, or other cultural institution (Figure 5.5). 


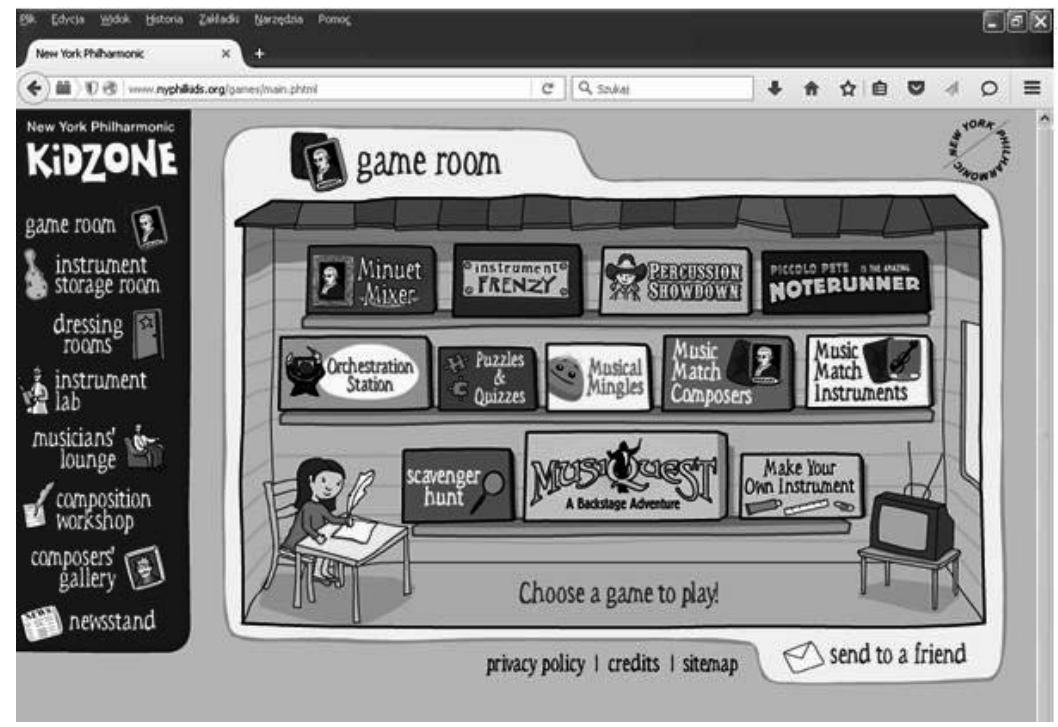

Figure 5.5 "Kidzone" - an educational project of the New York Philharmonic. Source http://www.nyphilkids.org/composition/main.phtml (accessed 3 Feb 2016)

An example of a very interesting multimedia educational project for children is the series "Moni i Uszko" posted on the official website of the National Opera in Warsaw (Figure 5.6).

"Moni i Uszko" is a multimedia series in which young viewers are exposed in a very accessible way to a lot of important information about the opera. What to wear? How to get to the place without using GPS? Why is it better to arrive at the theater too early than too late, or what to do if your stomach starts to rumble during a show? These and many other often embarrassing questions are answered by animated characters - Moni and Uszko siblings who love the opera, but even more, they love getting in to trouble... The website features a booklet about the adventures of the characters, an animated series about their greatest blunders, as well as unique games, thanks to which young opera lovers will find that the Grand Theater can be very interesting for them as well. 




Figure 5.6 "Moni i Uszko" - a multimedia series for kids from the National Opera in Warsaw. Source http://katila.com.pl/TeatrWielki/GraMoniUszko-wTeatrze/ (accessed 3 Feb 2016) 


\section{Social media as a tool for marketing communication of entities in the cultural sector}

The development of new media and modern information and communication technologies contributes significantly to changes in the forms of satisfying needs and the participation of individuals in social life, including in culture (Sparacino 2004, Scott 2011, Karaman et al. 2013, Barrera eta al. 2013, Jones 2016, Rialti et al. 2016). This is reflected in the development of the information society and a society based on knowledge. This state of affairs has established new opportunities for creativity, distribution, and importantly, the marketing communication of cultural institutions. This has been accompanied by a change in the role played by the consumer of culture, who through the use of modern technology and new media is no longer only a consumer, but also becomes an active participant in the processes of the creation and dissemination of works of art (Figure 5.7).



Figure 5.7 New look at the role of a participant in culture in the process of value management. Source Sobocińska (2015: 139)

The presence of entities from the cultural sector in social media in the twenty-first century has therefore become very important. It offers new possibilities for communication and allows the involvement of selected segments of Internet users in interacting with the 
profile associated with a given cultural institution. These interactions can of course take a different character, depending on the nature of the given social media and its options (for example following a page or a profile, giving a "like", or subscribing). These interactions in the cultural sector are gaining in importance each year as they combine the advantages of mass communication and direct communication, allowing for contact with many customers and potential customers at the same time, while personalizing individual messages.

\subsection{The goals and importance of using social media in the marketing communication of cultural entities}

The cultural sector is using new media more and more, especially the Internet, which has been growing continuously for over twenty years (Figure 5.8). In an era of increasing competition and technological and technical progress, it has become a marketing tool used by virtually all organizations, including entities in the cultural sector.



Figure 5.8 Trends in the growth of the Internet. Source Sznajder (2015: 208) 
As shown in Figure 5.8, the number of Internet users is increasing regularly. There are also important qualitative changes which have an impact on new possibilities for the marketing communication strategy. Websites, Facebook profiles, or YouTube channels are becoming the foundation of building long-term relationships, creating the image of a cultural institution, and the primary source of information about the organization, its activities, and offer. However, a study conducted by Sobocińska (2015: 214) shows that not all managers of cultural institutions are fully aware of these facts. Although almost all of the Polish cultural institutions which participated in the study (451 institutions) have their own website (99.1\%), only $77.4 \%$ of them have a Facebook profile. An even smaller proportion of the institutions get their customers involved in the promotion and sales on the Internet (54.3\%). At the same time, Sobocińska's research (2015) confirms that social media are gaining in importance and are becoming a more important tool in communication with the market. The same conclusions can be drawn from the research I carried out on a group of 230 consumers of the offer of cultural institutions in the area of the Euroregion Śląsk Cieszyński in 2015 and 2016 (Wróblewski 2016). Table 5.1 presents the most important goals in the use of social media in the cultural sector, which were indicated by the surveyed managers of 451 entities in the cultural sector in Poland.

Table 5.1 Objectives for the use of social media in various types of cultural institutions

\begin{tabular}{l}
\multicolumn{1}{l}{ Type of cultural institution } \\
$\begin{array}{l}\text { Purpose of using } \\
\text { social media }\end{array}$
\end{tabular}

The results do not add up to $100 \%$ because respondents were able to select three answers.

Source Sobocińska (2015: 209) 
As the main goals of using social media, those who manage the cultural institutions which were subjects of the analysis mentioned the creation of the cultural institution's image, developing relationships with consumers of culture, and advertisement of the cultural institution. This was indicated by $71.2 \%, 51.3 \%$ and $44.9 \%$ of the respondents, respectively.

In recent years, the range of applications of the Internet in the marketing activities of cultural institutions has increased. This can be seen in the high percentages of Polish cultural institutions which, for at least one year but not more than 10 years, have been advertising on the Internet $(71.2 \%)$, have their own website $(68.5 \%)$, have a Facebook profile $(62.5 \%)$, or sell cultural goods via the Internet (56.8\%) (Sobocińska 2015). This should be seen as a response of entities in the cultural sector to new trends in consumer behaviors that are associated with a virtualization of the consumer's decision-making process relating to purchases in the cultural sector.

It is hard to overestimate the importance of the group of solutions which is growing on a daily basis, covering a wide range of different, often intersecting tools, based on the philosophy of Web 2.0. The most popular modern tools of this type include (Kaplan and Haenlein 2010, Kopera 2009: 422, Woodcock et al. 2011: 64, Baird et al. 2011: 4):

- Social networking sites;

- Media sharing sites;

- Blogging and micro-blogging websites;

- Sites using Wiki mechanisms;

- Social review sites and social bookmarking sites;

- Forums and discussion groups;

- Internet auctions;

- Channels aggregating content, interactive applications, webinars, or instant messengers.

In cultural institutions, the most frequently used social media include profiles on Facebook, Twitter, YouTube channels, and blogs. Confirmation of this is the fact that these tools (except for blogs) have been used for years by all the theaters in Warsaw (Table 5.2). 
Table 5.2 Social media in the activities of Warsaw's theaters, as of 04.02.2016

\begin{tabular}{|c|c|c|c|c|c|c|}
\hline \multirow[t]{2}{*}{ Theater name } & \multirow[b]{2}{*}{ Launch date } & \multicolumn{3}{|c|}{ YouTube channel } & \multirow{2}{*}{$\begin{array}{l}\text { Facebook } \\
\text { number of } \\
\text { likes }\end{array}$} & \multirow{2}{*}{$\begin{array}{c}\text { Twitter } \\
\text { number of } \\
\text { followers }\end{array}$} \\
\hline & & $\begin{array}{l}\text { Number of } \\
\text { subscriptions }\end{array}$ & $\begin{array}{l}\text { Number of } \\
\text { views }\end{array}$ & $\begin{array}{l}\text { Number of } \\
\text { videos }\end{array}$ & & \\
\hline $\begin{array}{l}\text { Dramatic Theater of the } \\
\text { Capital City of Warsaw }\end{array}$ & 27.06 .2008 & 279 & 385,410 & 189 & No profile & 2 \\
\hline Rozmaitości Theater & 27.08 .2008 & 468 & 550,823 & 295 & 16,097 & No profile \\
\hline Rampa Theater & 12.02 .2010 & 158 & 171,547 & 73 & 10,636 & 5 \\
\hline 6th Floor Theater & 14.02 .2010 & 411 & 739,438 & 116 & 42,833 & 79 \\
\hline $\begin{array}{l}\text { Polish Theater } \\
\text { in Warsaw }\end{array}$ & 10.03 .2010 & 229 & 174,488 & 109 & 17,351 & 328 \\
\hline $\begin{array}{l}\text { Zygmunt Hübner } \\
\text { Powszechny Theater in } \\
\text { Warsaw }\end{array}$ & 04.11 .2010 & 105 & 77,766 & 47 & 20,121 & 82 \\
\hline Musical Theater ROMA & 07.02 .2011 & 1252 & 760,475 & 44 & 52,566 & No data \\
\hline $\begin{array}{l}\text { Polonia Theater } \\
\text { and Och-Teatr }\end{array}$ & 07.11 .2011 & 208 & 396,384 & 58 & $\begin{array}{l}27,397 \\
29,884\end{array}$ & No data \\
\hline $\begin{array}{l}\text { Kwadrat } \\
\text { Theater }\end{array}$ & 11.04 .2012 & 166 & 171,418 & 39 & 32,717 & 112 \\
\hline Syrena Theater & 30.11 .2012 & 72 & 194,353 & 54 & 8,269 & No data \\
\hline Komedia Theater & No data & 36 & No data & No data & 14,203 & No data \\
\hline Sabat Theater & No data & 24 & No data & No data & 5,918 & No data \\
\hline $\begin{array}{l}\text { The Ester Rachel } \\
\text { Kamińska } \\
\text { and Ida Kamińska } \\
\text { State Jewish Theater }\end{array}$ & No data & 45 & No data & No data & 10,897 & 4 \\
\hline $\begin{array}{l}\text { Theater of the Little } \\
\text { Spectator }\end{array}$ & No data & 7 & No data & No data & 10,182 & 718 \\
\hline Ateneum Theater & No data & 92 & No data & No data & 8,832 & 33 \\
\hline Współczesny Theater & No data & 81 & No data & No data & 6,697 & No profile \\
\hline Capitol Theater & No data & 25 & No data & No data & 20,406 & No profile \\
\hline $\begin{array}{l}\text { The } \\
\text { Studio Theater }\end{array}$ & - & - & - & - & 18,224 & 13 \\
\hline National Theater & - & - & - & - & 11,775 & 6 \\
\hline Studio Buffo Theater & - & - & - & - & 19,745 & No data \\
\hline Kamienica Theater & - & - & - & - & 16,511 & No data \\
\hline
\end{tabular}


The managers of Warsaw theaters are aware of the great importance of social media. Facebook profiles are the most popular among the theaters - only the Dramatic Theater of the Capital City of Warsaw does not have one. The Musical Theater ROMA has the most likes for this type of profile - more than 52,000. This theater also has the largest number of subscriptions to its YouTube channel (1,252 subscribers) and the highest (among Warsaw theaters) number of views of this channel - more than 760,000. A Twitter profile is definitely less popular among Warsaw theaters - the highest number of likes for this type of profile was achieved by the Theater of the Little Spectator (718 likes).

When using social media in the cultural sector we should be aware that they are governed by somewhat different rules than the typical marketing communication tools. The particularly important ones are: openness, transparency, informality, and equality of users. An important implication of these characteristics is a willingness for sincere dialogue with users. We must understand that interactions with the community (often anonymous) can be both positive and negative. The latter ones, criticizing the cultural institution and initiatives and subjects presented, are especially difficult. Examples include harassing comments on posts made by artists appearing on social networks, or often non-related comments on film materials posted on YouTube. In addition, there still remains the rational and substantive criticism of the material which has been published and related activities, which often cannot be simply ignored. Its existence requires the cultural institution to determine appropriate guidelines in such cases. Of course there is also the option of disabling the possibility to comment, but this takes away invaluable feedback, thanks to which the institution can improve its operations and adapt them to the needs of its customers (Kopera et al. 2014: 5572).

\subsection{Segmentation of social media users in relation to cultural institutions}

Consumers of culture use new media and new technologies in varying degrees. The development of the information society and its associated civilizational changes are accompanied by the formation of new class divisions which reveal the attitudes of different 
social groups to new technology. In a report published in March 2014 in the Journal of Advertising Research researchers from universities in Ireland, the UK and Spain presented four categories of people who use the social networking profiles of different organizations and their motivation for liking content on Facebook (Wallace et al. 2014: 92-109). Research carried out on a sample of 438 individuals can be extended to the users of other social networks and these segments, after relevant modifications and additions, can be transferred to entities in the cultural sector. The characteristics of the segments are based on several factors: actual interest in the content on the page, the need to create one's own image, incentives proposed by the website (promotions, competitions etc.), the strength of social relationships, homophily (liking things similar to oneself), self-control, being a leader of opinions or searching for recommendations from others, and degree of materialism and selfesteem. The differentiated segments of Internet users who use the profiles of cultural institutions on social media are:

- In love with the institution (event, brand) - they are strongly associated with the cultural institution - they love it. They build their social position (the highest possible) and a network of contacts on social media, which results in generating more interest around the institution. By liking selected pages or joining events which are popular in some circles on the profile, they want to present themselves in the best light. They have a high level of self-control (they do not click thoughtlessly on pages or events), have high self-esteem, a high level of materialism, and describe themselves as opinion-leaders. According to research results, Facebook is invaluable for this group as a source of information, a means to achieve membership to a social group and as a tool to create the desired image.

- Image creators - they "like" profiles in order to impress other people with similar interests and views. They are, however, less tied to the institution than those who are in love with it. This group produces the most content and "shares", which are used to create their image on the Internet (their desired image). They have a high level of self-control, but rather low self-esteem, which they want to increase by sharing prestigious news and events on the profile. The profiles which are liked, participation 
in events "which are worth participating in", or comments left are the means to achieve this objective.

- The genuine ones - they do not pay attention at all to the fact that liking specific pages or joining prestigious special events affects their image. They show a genuine interest in the institution, which they like and respect. They are very loyal to the institution, appreciate it, and share information about it. The profiles they like most often actually reflect their interests. They have a low level of materialism and poor self-control. These individuals probably seek the advice and opinions of others. Their social ties on the Internet and beyond it are very strong, and the social networking site for them is a virtual extension of the social environment of their real life.

- Practical ones - they like the given sites because they get something in return: e.g. an offer to purchase tickets at a promotional price, the opportunity to participate in special events (e.g. meeting with the artist after the concert, performance), vouchers for promotional items, etc. These people often invite others to participate in surveys, give a "like" to a photo entered in a contest, and to other activities. They have no connection with the institution's pages and do not perceive liking specific profiles as a way to create their own image. It is interesting that the people in this group believe they have a lower level of materialism than in reality. They are also the least interested in passing information on to others and searching for it among friends. They have an average level of self-control and are the segment that attaches the least importance to creating their own image on the profile by liking pages and participating in events.

The segmentation of Internet users using the cultural institutions' social media is a clear manifestation of a focus on the market and one of the main stages in the development of online marketing strategy. The use of new technology in the management of cultural institutions is seen as a factor stimulating their further development because it means that consumer needs are met in a better way by increasing the availability of cultural goods and information about them. 


\subsection{Fan pages in the marketing activities of cultural institutions}

The aim of marketing activities which are implemented by cultural institutions through social networking sites (fan pages) is primarily cultural education, connected to improving the image of the cultural institution, shaping relationships with the consumers of culture, as well as activities that promote the institution and its offer. This form of marketing communication is used, without exception, by the most significant cultural institutions in the world - proof of this is are the fan pages of the largest and most renowned opera houses (Table 5.3).

Table 5.3 Facebook and Twitter in the activities of the leading opera houses in the world, as of 04.02.2016

\begin{tabular}{|c|c|c|c|c|c|}
\hline Cultural institution & $\begin{array}{l}\text { Headquarters of } \\
\text { the institution }\end{array}$ & $\begin{array}{l}\text { Number of } \\
\text { likes } \\
\text { Facebook }\end{array}$ & $\begin{array}{l}\text { Number of } \\
\text { followers } \\
\text { Twitter }\end{array}$ & $\begin{array}{c}\text { People talking } \\
\text { about it } \\
\text { Facebook }\end{array}$ & $\begin{array}{l}\text { Number of } \\
\text { people } \\
\text { registered } \\
\text { Facebook }\end{array}$ \\
\hline Sydney Opera House & Sydney - Australia & & & & \\
\hline The Metropolitan Opera & $\begin{array}{l}\text { New York - } \\
\text { United States }\end{array}$ & $\begin{array}{l}634,583 \\
354,743\end{array}$ & $\begin{array}{l}2659 \\
1779\end{array}$ & $\begin{array}{c}14,519 \\
9139\end{array}$ & $\begin{array}{c}1,498,469 \\
228,356\end{array}$ \\
\hline Royal Opera House & $\begin{array}{c}\text { London - United } \\
\text { Kingdom }\end{array}$ & 222,888 & 6800 & 9983 & 228,690 \\
\hline Teatro alla Scala & Milan - Italy & 183,898 & 89 & 3306 & 139,907 \\
\hline Teatro Colón & $\begin{array}{c}\text { Buenos Aires - } \\
\text { Argentina }\end{array}$ & 130,174 & 495 & 5038 & 142,576 \\
\hline Opera National de Paris & Paris - France & 128,988 & 988 & 2232 & 36,679 \\
\hline Wiener Staatsoper & Vienna - Austria & 70,553 & 196 & 2246 & 98,898 \\
\hline Opera di Roma & Rome - Italy & 52,053 & 961 & 2745 & 6579 \\
\hline National Opera in Warsaw & Warsaw - Poland & 37,437 & No profile & 1310 & 38,706 \\
\hline Marinsky Theater & $\begin{array}{c}\text { Saint Petersburg - } \\
\text { Russia }\end{array}$ & 36,372 & 1309 & 4103 & - \\
\hline Bolshoi Theater & Moscow - Russia & 33,945 & 2609 & 1533 & 53,940 \\
\hline Teatro Real & Madrid - Spain & 32,549 & 4167 & 7638 & 36,530 \\
\hline Gran Teatre del Liceu & Barcelona - Spain & 30,024 & No profile & 2566 & - \\
\hline San Francisco Opera & $\begin{array}{l}\text { San Francisco - } \\
\text { United States }\end{array}$ & 29,201 & 7287 & 356 & 33,295 \\
\hline Deutsche Oper Berlin & Berlin - Germany & 24,753 & 1686 & 727 & 32,176 \\
\hline
\end{tabular}


The definitive leader in terms of the number of likes, number of people talking about it, and the number of people registered on Facebook is the Sydney Opera - respectively 634,583, 14,519 and 1,498,469. Almost all the opera houses analyzed also have a Twitter account as well as a fan page on Facebook, except for the National Opera in Warsaw and the Gran Teatre del Liceu in Barcelona.

Facebook and Twitter are growing and with them the objectives of activities in social media should also change. We cannot, or at least should not, look at them in the light of the past years. If, regardless of the chosen target, a cultural institution only pays attention to the number of likes, subscriptions, or shares, the official profiles of these institutions will ultimately become meaningless. It is consequently vital that social profiles are seen as a comprehensive tool that when properly used can increase the efficiency of operations. Therefore, the quality of the content created which is built day by day is invariably the most important and actually that is the main, non-negotiable criterion, which should guide us in conducting any activities on Facebook. A social profile also very often acts as an additional contact point and a customer service point. Such a function cannot be underestimated. Thanks to a fan page, entities in the cultural sector can test the moods prevailing among their customers and fans. Fan pages can help diagnose what they particularly like or not in order to react appropriately. Cultural institutions - especially those financed from the state or local budget - will, however, need to alter the way they think when it comes to investing in this medium. Large institutions - such as the opera houses listed in Table 3 - are already well aware of this, but a significant portion of smaller, local cultural institutions have yet to learn that social media is not an addition which can be "looked after" by anyone who can create their own Facebook profile. 


\subsection{The possibilities of using YouTube in the promotion of entities in the cultural sector}

Entities in the cultural sector carry out incredibly diverse, multi-directional activities for the promotion of culture in social media. Increasingly, these activities also include an official video channel on YouTube. YouTube is a web service (created in 2005), which allows users to post and play videos for free (Walotek-Ściańska 2015: 176). This channel is part of a wider, coherent set of activities and is used by the institution in various areas of its activity. Entities in the cultural sector can, for example, show trailers, excerpts of performances, concerts, interviews with artists, or can run a video blog. They can also broadcast live selected events to audiences around the world. YouTube is the ideal platform for entities in the cultural sector with an extensive number of video content, or - even better - the means for their production (e.g. opera houses, concert halls, theaters, film studios). It has an enormous power of influence, especially on young consumers of the cultural offer, of which the most renowned cultural institutions of the world are fully aware (Table 5.4).

Table 5.4 YouTube in the activities of leading opera houses, as of 04.02.2016

\begin{tabular}{|c|c|c|c|c|c|c|}
\hline Opera house & Location & $\begin{array}{l}\text { Launch date of } \\
\text { the channel }\end{array}$ & $\begin{array}{l}\text { Number of } \\
\text { subscriptions } \\
\text { to the channel }\end{array}$ & $\begin{array}{c}\text { Number of } \\
\text { channel } \\
\text { views }\end{array}$ & $\begin{array}{c}\text { Number of } \\
\text { films } \\
\text { available }\end{array}$ & $\begin{array}{l}\text { Indicator } 1 \\
\text { Indicator } 2 \\
\text { Indicator } 3\end{array}$ \\
\hline Bolshoi Theater & $\begin{array}{l}\text { Moscow - } \\
\text { Russia }\end{array}$ & 05.11 .2005 & 28,242 & $2,096,581$ & 280 & $\begin{array}{c}230 \\
17,045 \\
2.28\end{array}$ \\
\hline $\begin{array}{l}\text { Sydney Opera } \\
\text { House }\end{array}$ & $\begin{array}{l}\text { Sydney - } \\
\text { Australia }\end{array}$ & 19.09.2006 & 9,079 & $4,976,584$ & 607 & $\begin{array}{c}81 \\
44,434 \\
5.42\end{array}$ \\
\hline Royal Opera House & $\begin{array}{l}\text { London - } \\
\text { United } \\
\text { Kingdom }\end{array}$ & 04.06 .2007 & 163,903 & $43,163,992$ & 955 & $\begin{array}{c}1576 \\
415,038 \\
9.18\end{array}$ \\
\hline Teatro alla Scala & Milan - Italy & 07.11 .2007 & 7,062 & $1,398,748$ & 317 & $\begin{array}{c}71 \\
14,128 \\
3.2\end{array}$ \\
\hline Metropolitan Opera & $\begin{array}{l}\text { New York - } \\
\text { United States }\end{array}$ & 09.01.2008 & 27,222 & $8,416,420$ & 402 & $\begin{array}{c}281 \\
86,767 \\
4.14\end{array}$ \\
\hline $\begin{array}{l}\text { San Francisco } \\
\text { Opera }\end{array}$ & $\begin{array}{l}\text { San Francisco - } \\
\text { United States }\end{array}$ & 20.01.2008 & 1,878 & 905,200 & 458 & $\begin{array}{c}20 \\
9,429 \\
4.77\end{array}$ \\
\hline
\end{tabular}




\begin{tabular}{|c|c|c|c|c|c|c|}
\hline Opera di Roma & Rome - Italy & 19.02 .2008 & 1,435 & $1,315,978$ & 166 & $\begin{array}{c}15 \\
13,852 \\
1.75\end{array}$ \\
\hline $\begin{array}{l}\text { Gran Teatre del } \\
\text { Liceu }\end{array}$ & $\begin{array}{l}\text { Barcelona - } \\
\text { Spain }\end{array}$ & 02.12 .2008 & 5,870 & $4,446,967$ & 991 & $\begin{array}{c}68 \\
51,708 \\
11.52\end{array}$ \\
\hline $\begin{array}{l}\text { National Opera in } \\
\text { Warsaw }\end{array}$ & $\begin{array}{l}\text { Warsaw - } \\
\text { Poland }\end{array}$ & 20.02.2009 & 1,540 & $1,109,629$ & 217 & $\begin{array}{c}19 \\
13,369 \\
2.61\end{array}$ \\
\hline Marinsky Theater & $\begin{array}{c}\text { Saint } \\
\text { Petersburg - } \\
\text { Russia }\end{array}$ & 29.04 .2009 & 4,444 & $1,883,115$ & 472 & $\begin{array}{c}55 \\
23,248 \\
5.83\end{array}$ \\
\hline $\begin{array}{l}\text { Opera National de } \\
\text { Paris }\end{array}$ & Paris - France & 30.03 .2010 & 8,040 & $1,679,852$ & 281 & $\begin{array}{c}115 \\
23,997 \\
4.01\end{array}$ \\
\hline $\begin{array}{l}\text { Deutsche Oper } \\
\text { Berlin }\end{array}$ & $\begin{array}{l}\text { Berlin - } \\
\text { Germany }\end{array}$ & 21.04 .2010 & - & 406,623 & 101 & $\begin{array}{c}- \\
5,893 \\
1.46\end{array}$ \\
\hline Teatro Real & Madrid - Spain & 18.08.2010 & 2,390 & 814,599 & 207 & $\begin{array}{c}37 \\
12,532 \\
3.18\end{array}$ \\
\hline Teatro Colón & $\begin{array}{c}\text { Buenos Aires - } \\
\text { Argentina }\end{array}$ & 09.04 .2012 & 2,359 & 139,400 & 38 & $\begin{array}{c}51 \\
3,030 \\
0.83\end{array}$ \\
\hline Wiener Staatsoper & $\begin{array}{l}\text { Vienna - } \\
\text { Austria }\end{array}$ & 22.04 .2013 & 1,810 & 364,813 & 186 & $\begin{array}{c}53 \\
10,729 \\
5.47 \\
\end{array}$ \\
\hline \multicolumn{7}{|c|}{$\begin{array}{l}\text { Indicator } 1 \text { - Averaged number of subscriptions to the opera house's YouTube channel per month since the } \\
\text { launch of the channel (total number of channel subscriptions divided by the number of months since the launch } \\
\text { of the channel). Indicator } 2 \text { - Averaged number of views of the opera house's YouTube channel per month } \\
\text { since the launch of the channel (total number of channel views divided by the number of months since the } \\
\text { launch of the channel). Indicator } 3 \text { - Averaged number of videos uploaded to the YouTube channel by the } \\
\text { institution per month since the launch of the channel (total number of all videos uploaded divided by the } \\
\text { number of months since the launch of the channel). }\end{array}$} \\
\hline
\end{tabular}

The official YouTube channel of the Royal Opera House in London (Figure 5.9), which contains nearly 1000 videos, has been viewed over 43 million times, and the number of channel subscriptions is close to 164,000 . The average monthly number of channel views since its launch by the institution in June 2007 has totaled over 415,000. The Gran Teatre del Liceu in Barcelona has the greatest number of videos posted on YouTube (on average per month since the launch of the channel). 


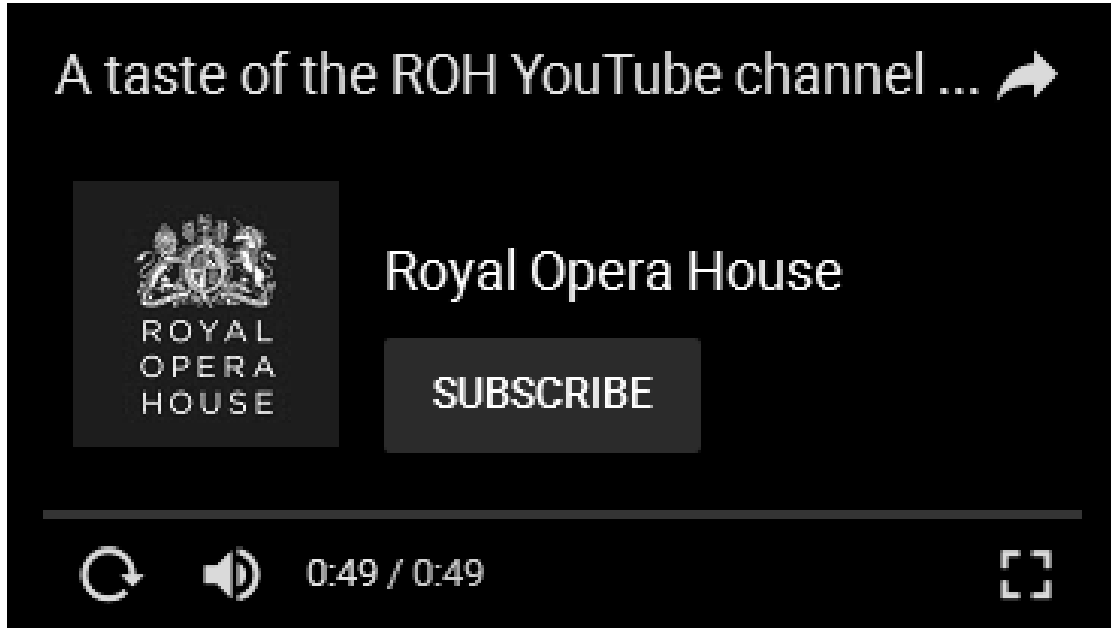

Figure 5.9 YouTube channel of the Royal Opera House in London.

Source https://www.youtube.com/user/RoyalOperaHouse (accessed 20 Aug 2016)

Videos posted on YouTube can relate to various aspects of the institution, supporting the implementation of its objectives in a comprehensive manner. The materials posted can inform viewers about the activities of the organization, its offer, its projects and initiatives, thereby facilitating more informed decision-making by the persons concerned. It is also worth noting the image-enhancement aspect of this enterprise, both for the cultural entity, as well as the city or region in which it operates.

\subsection{Blogs as a specific tool for the communication of cultural institutions} with the market

A blog as a communication tool is by assumption an honest form, resulting from the very real need to make contact with another person who is interested in the same things and cares about what the blogger has to say: individual stories, events, thoughts, meetings, passions. A blog is a form of a commentary, essay, or magazine article, but it is never simply the sum, selection, and compilation of traditional genres (Kawka 2010: 64-65). It is a text about various topics which has a variety of forms. It assumes interactivity, not anonymity or 
intimacy. It consists of a number of posts (messages), marked with a date and arranged chronologically. The reader sees the latest post at the top. A blog can be run in the "traditional" form, or also in the form of a video blog, audio blog, micro blog, or moblog (mobile blog) (Walotek-Ściańska 2015: 180-181). This tool is also worth using by entities in the cultural sector because people are often more willing to trust another person than the institution itself. If a blogger, who should be an authority to the consumer, makes use of the offer of a specific cultural institution, then this is definitely a stronger incentive to try it yourself than an ordinary advertising message. When planning a campaign, a cultural institution should, however, specify exactly its main purpose and who it wants to reach. Only on this basis is it possible to select the author, the blog's moderator, and its target audience (a blogger is to no avail, and may even be the cause of unwanted confusion, if he is not the right person for the task). As a result, there is a very high probability that the institution's message will reach the target customer profile, those most likely interested in the topic. An additional benefit of this type of action is the ability to get feedback (statistics regarding page visits, addresses, and number of guests) as well as opinions for building the image of the cultural institution online. A well-run blog, which effectively builds a community around the institution, is a storytelling type of blog. It cannot be reduced solely to reporting what is currently taking place in the cultural institution, or presenting the offer of the cultural institution. It is rather a space where readers are offered a compelling and personal story on a given topic. An example of such a blog is "Weissblog", which is run by the Director of the Baltic Opera in Gdańsk (Figure 5.10). Mr Weiss runs his blog in a very professional manner, because each post is related to the subject of the opera, but it also touches on the personal life of the author, politics, and social issues. In addition, blog posts are in the form of essays, which means that the posts read like a good novel. 


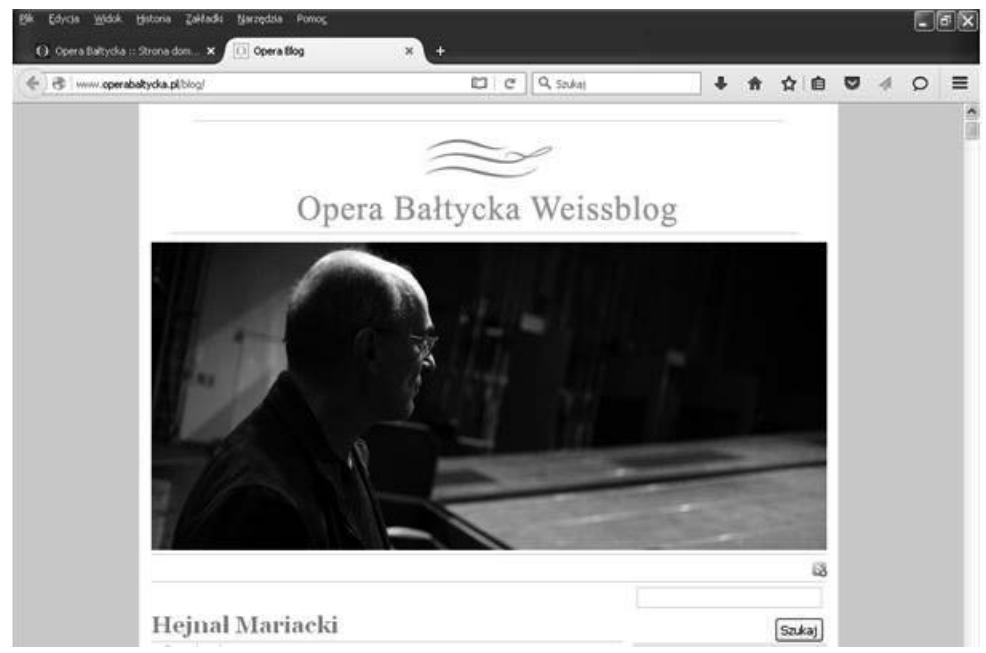

Figure 5.10 Weissblog - blog of the Baltic Opera.

Source http://www.operabaltycka.pl/blog/ (accessed 8 Feb 2016)

A well-run blog is a great tool for building long-term relationships between a cultural institution and the consumers of its offer. It is a tool focused on communication and based on the belief that consumers are capable of promoting something well - for example, they will start to comment on posts in large numbers, and more importantly will link to them on their blogs or on social networking sites. However, blogs are rather suitable as a complementary campaign, especially where the institution is very confident of the quality of its products and is also certain that reviews of the bloggers will be positive.

\section{Possibilities of using holograms and virtual advisors in the cultural sector}

The advanced development of technological systems brings with it the possibility of applying new solutions in the cultural sector. There is no doubt that today, in many cases, the promotion of cultural entities and their offer is possible through the use of ICT, which often eliminates the need for direct contact and increases the speed of the execution of tasks. New ideas and solutions that until recently were regarded only as scenarios for science fiction films are beginning to take the form of real activities. An example of this might be the 
dissemination of so-called virtual advisors or the commercialization of holograms in the cultural sector, which had previously been absorbed by the entertainment industry (Lehman and Roach 2011, Neuhofer et al. 2014, Walmsley 2016).

A virtual advisor (correspondent, presenter, assistant) is a computer program designed to conduct an intelligent conversation using text or speech. The aim of these programs is to conduct a conversation in such a manner that the user thinks they are talking to a human, not a machine. Virtual advisors don't have their own consciousness, but in a sense, they have understanding and form their answers. A virtual advisor often consists of elements such as a visualization of the character, a machine generating speech and - in the expanded version other additional elements (e.g. a speech recognition module, tracking the user's eyes) (Gołuchowski and Spyra 2014: 339-340). A virtual advisor not only accompanies the Internet user during their visit to the website, but it is also connected to the knowledge database of the cultural entity (this is usually a set of standards and responses of the virtual advisor to the given pattern) and the CRM system. It conducts a conversation using an appropriate strategy aimed at helping navigation, giving information about the cultural institution and its offer, product sales, etc. In the cultural sector we can indicate the following areas of the application of virtual advisors in an online customer service:

- The area of customer service (for example, a virtual advisor chatting with users, when there is no "real" employee available; advisory, consulting and expert services);

- The entertainment area (for example, a virtual advisor "pulling in" the user to the site, game, or play);

- The promotional area (for example, a virtual advisor describing the cultural entity's offer, or a virtual spokesman);

- The organizational area (for example, a virtual assistant arranging appointments and visits at the museum, a virtual interviewer conducting surveys on expectations and customer satisfaction after a performance in the theater); 
- The transaction area (for example, a virtual salesperson helping internet users to go through the complex process of buying tickets online for a concert at the concert hall or opera).

The Polish Cluster of Culture and Industrial Tourism is an example of an entity in the cultural sector which uses a virtual advisor (Figure 5.11).

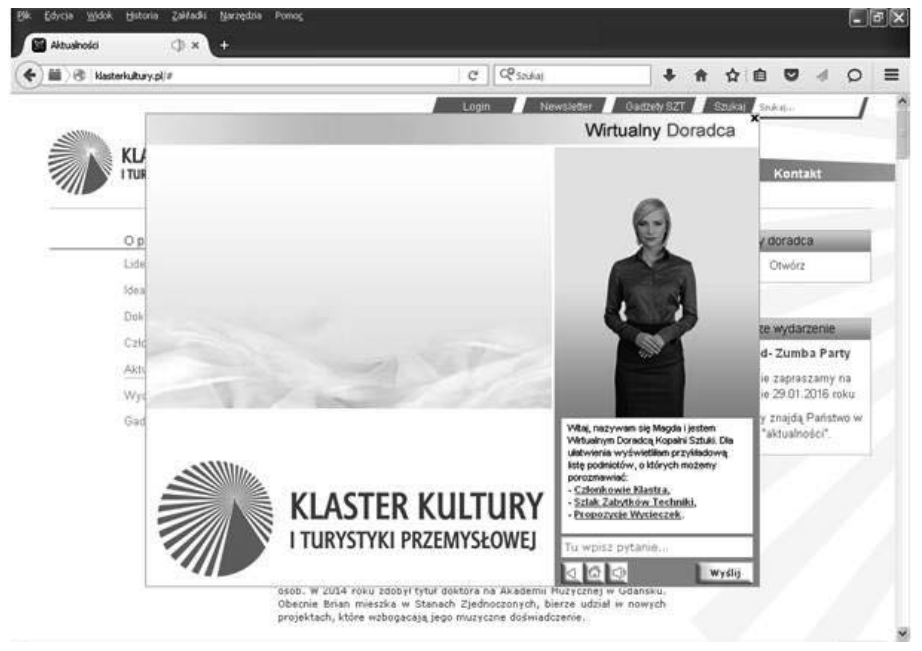

Figure 5.11 Virtual advisor of the Cluster Culture and Industrial Tourism screenshot. Source http://klasterkultury.pl/index.php?option=com_content\&view=article\&id=209: wirtualny-doradcamobilnie \&catid=8\&Itemid=110\# (accessed 30 Jan 2016)

An advisor can be installed on mobile devices: mobile phones, tablets, smartphones, etc. The application is available free of charge and its use provides easy access from anywhere to the knowledge database available to the virtual advisor.

The creation of a holographic image (avatar) according to the method developed by Dennis Gabor - a Nobel laureate - can be briefly described as follows: the object is displayed using monochromatic and consistent light so as to form a diffraction image, which interferes with a strong coherent wave forming a background; this image is fixed on a photographic plate. The Gabor method therefore consists of projecting the diffracted image of an object on a photographic plate with a background of coherent light used to produce the diffraction. The resulting photograph will contain information about the intensity of the diffracted beams, and their phase, that is, all the information needed to restore the image of the object. Then 
the hologram is illuminated using coherent light. A lens placed behind the hologram collects the curved beam together with the coherent wave, forming a background. Wave surfaces are reconstructed and a faithful optical image of the object is created. Holography uses the principle of interferometry in two-stage mapping (Kłóska 2015).

Holograms were used in the cultural sector for the first time in 2010, when a concert of a holographic character Hatsune-Miku was organized in Japan (Figure 5.12).



Figure 5.12 Holographic concert of Hatsume-Miku on YouTube.

Source http://www.polskieradio.pl/23/267/Artykul/275769,Gwiazdy-pop-przyszlosci-to-hologramy (accessed 1 Feb 2016)

Miku, an electronic creation singing with a synthesized computer voice, was accompanied by "real" musicians. The performances were accompanied by the applause of thousands of fans gathered at the concert, awed by the effect. The avatar was created on the Japanese website Vocaloid where users arrange songs for fictional characters. The Japanese company Crypton Future Media decided that it would create a hologram of such a character and organize its holographic concerts.

More spectacular, however, was the Coachella festival which was organized in California in April 2012 and which featured a "performance" by an avatar of Tupac Shakur, who died in 1996. After the success of this performance, Digital Domains Media Group 
announced that Marilyn Monroe and Elvis Presley would also "return" (Kłóska 2015). Holograms can be widely used in cultural entities, promoting events, institutions, or entire cities. It is possible to create a hologram of literally any person or fictional character, a wellknown artist, actor, or a composer. For example, in order to promote the city of Vienna in Poland Digital Emotions from Warsaw created an interactive version of the statue of Johann Strauss which gathered crowds of intrigued passers-by in Warsaw. The hologram also conducted a conversation with a hologram of Frederic Chopin (Figure 5.13).

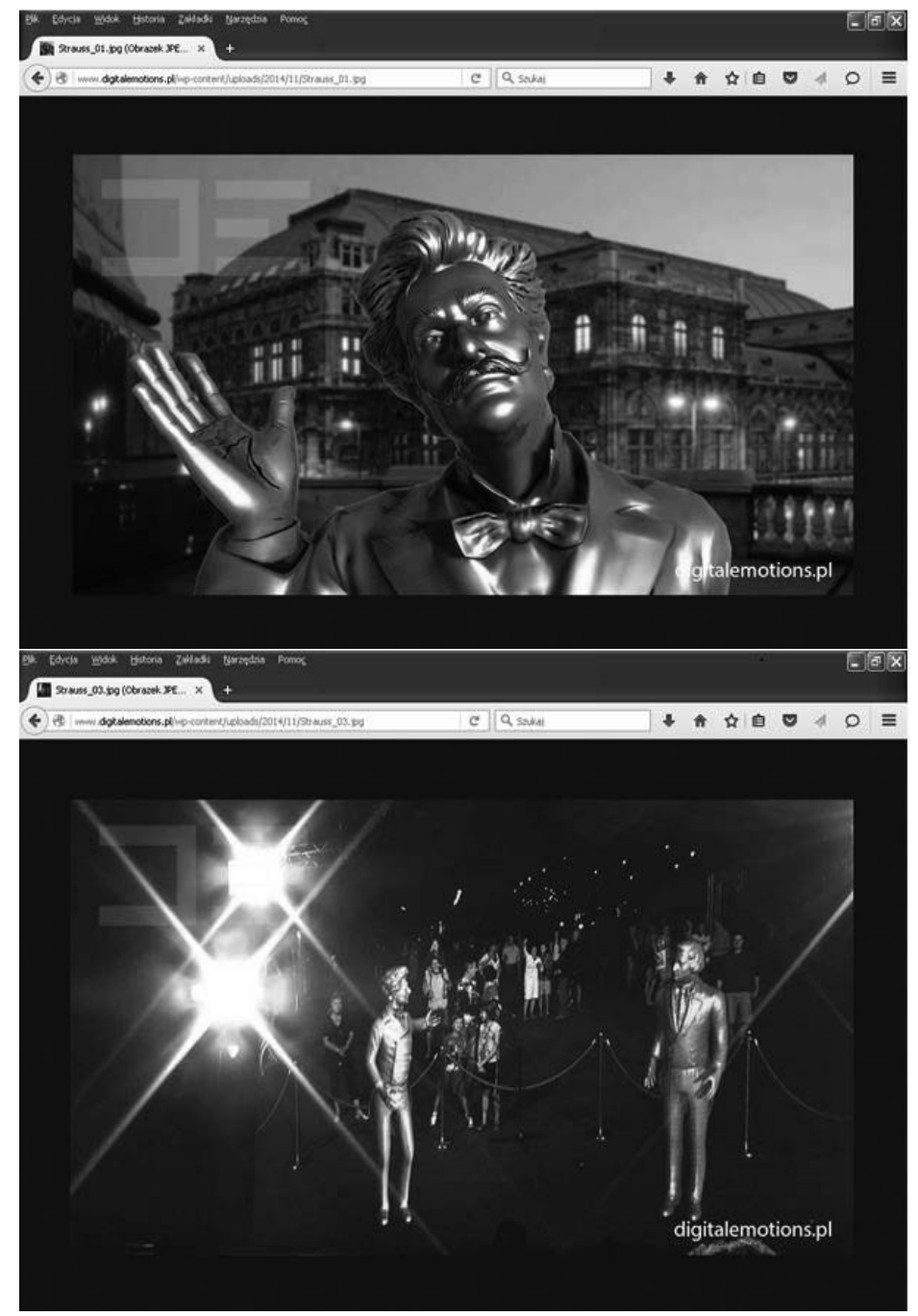

Figure 5.13 Hologram of the statue of Johann Strauss promoting the city of Vienna in Warsaw. Source http://www.digitalemotions.pl/projekty/ (accessed 1 Jan 2016) 
The virtual presenter, advisor, or interlocutor, who is a holographic presentation of a person, gives the impression of a real person with whom we can talk. A hologram presents the offer of the cultural entity; it is intelligent and is able to give a precise answer to questions asked by the customer. Its advantage is that it is "always in a good mood", "willing to help", and has a "permanent smile." A virtual presenter never loses his patience, has no "bad days", and never raises his voice, even when customers keep asking the same questions. On the contrary, rather than overwhelm customers with information, it just asks what the customer needs and gladly helps. Due to its interactivity, it attracts attention and makes a positive impression on customers. A virtual presenter presents the organization and its products in an innovative way. Such a modern and interactive form of communication enables the presentation of any product anywhere (in a museum, theater, or film première), and guarantees huge interest among the public.

The initiative to use holograms in the cultural sector is often described as highly controversial and extroverted, but not impossible. We must remember that the practical use of holograms brings many ethical dilemmas: most significantly, it increases the conflict regarding the commercial character of an organization. Having a three-dimensional technological lookalike, contemporary music bands will be able to give concerts in several places simultaneously, without the need for direct involvement in any of them. This means that for people who are still alive holograms generate passive income, but on the other hand, they are an alternative to expensive and inaccessible idols.

\section{Virtual tours as a modern form of presentation of cultural institutions}

A virtual tour or a virtual walk is the representation of a specific location in virtual reality. It is a collection of photographs of selected spots at the location of a cultural entity which is being presented, combined using an application so that interactive browsing is possible. Virtual walks (spherical panoramas) are multiple shots combined together into a series. Their number depends on the focal length of the lens - the lower it is, the less images are required. The best results can be achieved using a "fisheye" lens. Using a number of 
spherical panoramas, you can link them together and thus create a virtual tour. Panoramas are connected to each other via a network of dependencies. Such a network is created by adding active links to the panoramic images, which, when clicked, take the user to a specific area. A virtual tour usually consists of a map, photos, basic information about the place being presented, a description of the presented locations or exhibits, audio materials, and video files. The use of a virtual tour has the following advantages:

- A modern and original form of advertising;

- 3D presentation;

- The ability to accurately (realistically) present places, buildings, premises and their qualities;

- The ability of unlimited viewing in all planes;

- The ability of any movement using navigation tools;

- Increasing the attractiveness of the website;

- Presenting the advantages to a large number of potential customers and therefore the chance to attract new ones;

- Prestige associated with standing out in comparison to other sites;

- A higher level of customer satisfaction;

- The ability to visit the place from anywhere in the world, anytime (Goluchowski and Spyra 2014: 346).

Virtual tours are most commonly used in museums, galleries, theaters, or concert halls. They are also used in historic buildings such as churches. For example, St Mary's Church in Krakow - one of the most beautiful and famous churches in Poland - has created a virtual walk using gigapixel technology. This allows for high quality images and a high zoom ratio, which is a great advantage in the case of buildings with such a large number of details. Many design elements such as pulpits and altars have additional descriptions, from which you can often find out more than during a visit in person (Figure 5.14). 



Figure 5.14 Virtual tour of St. Mary's Church in Krakow.

Source http://www.pajorama.eu/wirtualnymariacki/mariacki.html\#/Prezbiterium/ (accessed 21 Aug 2016) 
Another example of a "virtual tour" is the 3D visualization which appeared on Cultura.pl before the Chopin Competition in 2010. In connection with the 200th anniversary of the birth of Frederic Chopin, which took place in 2010, the Adam Mickiewicz Institute, in cooperation with the OGX Group (Institute of Micromechanics and Photonics), carried out a project involving the multimedia visualization of the historic Ignaz Pleyel piano on which Chopin played and worked in Paris in the last years of his life (Figure 5.15).



Figure 5.15 Virtual piano of Chopin.

Source http://ogx.mchtr.pw.edu.pl/images/projects_chopin_3.jpg (accessed 3 Feb 2016)

The 3D digitization of the object was constructed using the scanning system 3DMADMAC developed by the OGX Group. A unique feature of the presentation is a fully interactive model of the piano with a detailed representation of its geometry, texture, the movement of individual elements, and the actual sounds it makes. By using 3DVIA Virtools technology, it is possible to explore the virtual object in an individual manner, selected by the user, and to enter into various interactions with three-dimensional objects. The main features of the presentation include:

- Recreated actual animation paths of the moving parts of the piano (e.g. keys, lid, music rest);

- Recreated real sounds recorded on a Pleyel piano owned by the Chopin Institute; 
- The possibility to play the instrument by clicking on the keys with a mouse or using the computer keyboard;

- The possibility to compose, record and play one's own songs;

- Synchronization of the movement of keys with the playback of the recordings saved;

- Informative texts, for example about Frederic Chopin in the years 1848 to 1849 , the composer's method of playing, and the history and construction of the piano, developed by renowned musicologists, including Prof. Irena Poniatowska and Prof. Benjamin Vogel.

The multimedia presentation allows lovers of Chopin's music to listen to four compositions: Prelude in E minor, Op. 28 No. 4, and Prelude in A major, Op. 28 No. 7 performed by Wojciech Świtała, Etude in E major, Op. 10 No. 3 performed by Tatiana Shebanova, and Polonaise in A-flat major, Op. 53 played by Janusz Olejniczak. The visualization is available in four languages: Polish, English, Japanese, and Chinese.

\section{Mobile applications in the cultural sector - case studies}

A mobile application is software designed for mobile devices, for example smartphones and tablets, typically distributed via online stores (e.g. Google Play, App Store, and Windows Phone Store). The uses of the applications change with the development of technology and user needs. Initially they fulfilled the function of office tools (e.g. a calendar, e-mail) or provided information (e.g. weather forecasts, stock quotes). As a result of further technological development and the popularization of smartphones and tablets, applications using, for example, geolocation (beacons) have been created and developed. A beacon is a transmitter which makes it possible to precisely locate the user within the building. It communicates wirelessly with a smartphone or tablet (within 70 meters). Through the application, content is sent to the device, which precisely matches the user's location and 
situational context. For many years, these applications have been used successfully as a tool for mobile marketing in various sectors, including, for several years, the cultural sector. A mobile application, supported by a system of wireless devices, can act as a guide to the museum building, deliver multimedia content, or co-create a gameplay. It can offer many unconventional features, for example, e-coupons, elements of rivalry, or navigation to the nearest museum, etc. And most importantly, it can effectively support cultural institutions in carrying out their missions, including carrying out their educational function. In Poland, the first to apply this technology was the Warsaw Neon Museum. Using the application we can access the gallery of archival images, videos, or a take a virtual tour. The MOCAK Museum of Contemporary Art in Krakow offers a mobile application to their visitors which, in conjunction with a network of beacons and QR codes, provides additional information about the painting which the visitor is standing in front of.

There is no simple, single recipe for a good mobile application. This does not mean that we have to create one blindly. It is definitely worth looking at products which have received awards from the interactive industry that have gotten users interested, as well as to reading experts' comments about their functions. Therefore, this section presents examples of selected mobile applications that can serve as an inspiration or a model to be used by entities in the cultural sector. These applications for the most part have been developed by Moiseum from Warsaw, which has won numerous awards for its solutions.

\section{1 "DailyArt" mobile application}

DailyArt is an application designed for iPhones, iPads, and Android phones which publishes one work of art a day with a brief interesting fact about it. This is something for those who do not have time to frequently visit museums and those who would like to refresh their knowledge of art. Although this is a very simple idea, it has turned out to have a gigantic effect - the application has been downloaded by thousands of people worldwide $(80,000$ as of March 2014) and has gained a wide fan base. The majority of visitors come from the United States (Figure 5.16). 


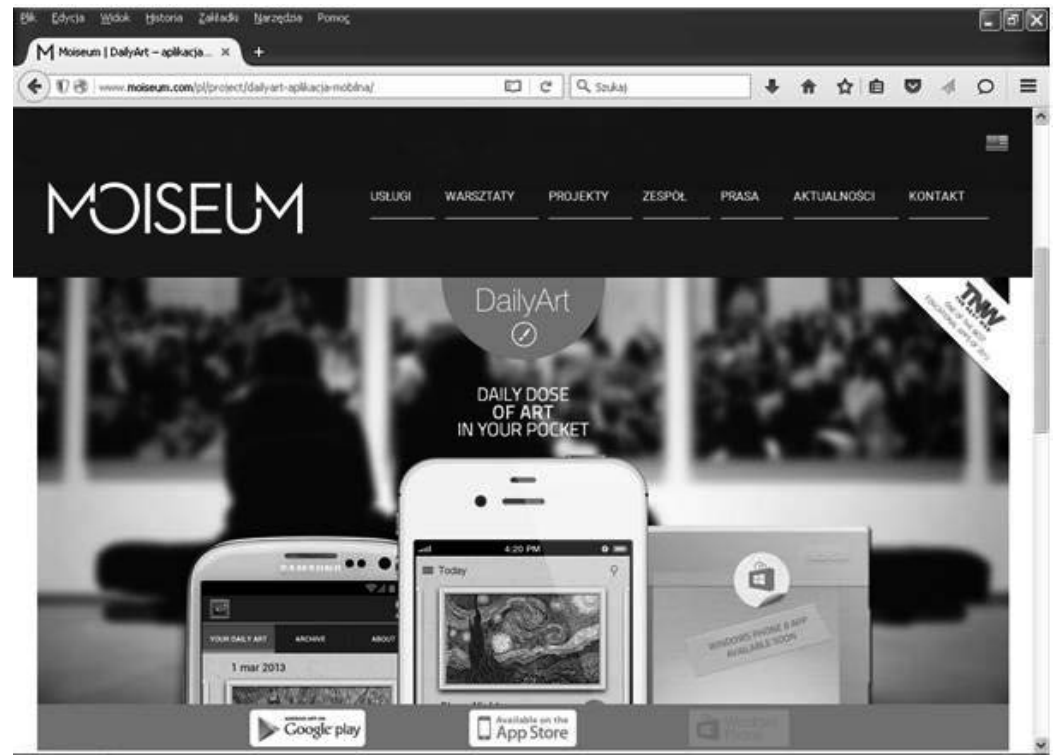

Figure 5.16 DailyArt application screenshot. Source http://www.moiseum.com/pl/project/dailyart-aplikacjamobilna/ (accessed 30 Jan 2016)

Very good reviews of DailyArt have been published by large international technology websites, for example Next Web, TUAW, Mashable, and VentureBeat. In addition, Next Web described DailyArt as one of the 12 best educational applications of 2012. The main objective of the application is to popularize art but not in an encyclopedia version. Each image hides a story behind it - the texts published in the application tell the story of the picture and the life and passions of the artists. DailyArt is available in two versions - free and pro, which work on the iPad, and has been expanded with the option of searching for works of art and adding them to your favorites. Texts in the application are published in English.

Two years after the release of the English version of DailyArt, a version of the application was introduced in Polish. It features Polish works of art. It is available in the App Store for free and it is intended for iPhones and iPads. Thanks to DailyArt PL, we can receive a Polish work of art regularly (twice a week) with a short story about it on our iPhone or iPad. This is not, however, a typical catalogue description, but a story which can be remembered for a long time. DailyArt PL is a completely free application designed for anyone who is interested in art and culture, including students. 


\section{2 “Wilanów Live” mobile application}

Cultural institutions that have successfully implemented mobile applications include Polish museums: the Museum of King Jan III's Palace at Wilanów, the Museum of the History of Polish Jews, and the Łódź City Museum. These institutions' applications largely serve the function of a mobile guide of the facility, providing additional information on the exhibit (e.g. using a built-in QR code scanner).

The mobile application "Wilanów Live" for iPhones and Android phones, created for the Museum of King Jan III's Palace at Wilanów, premièred in March 2014 (Figure 5.17).

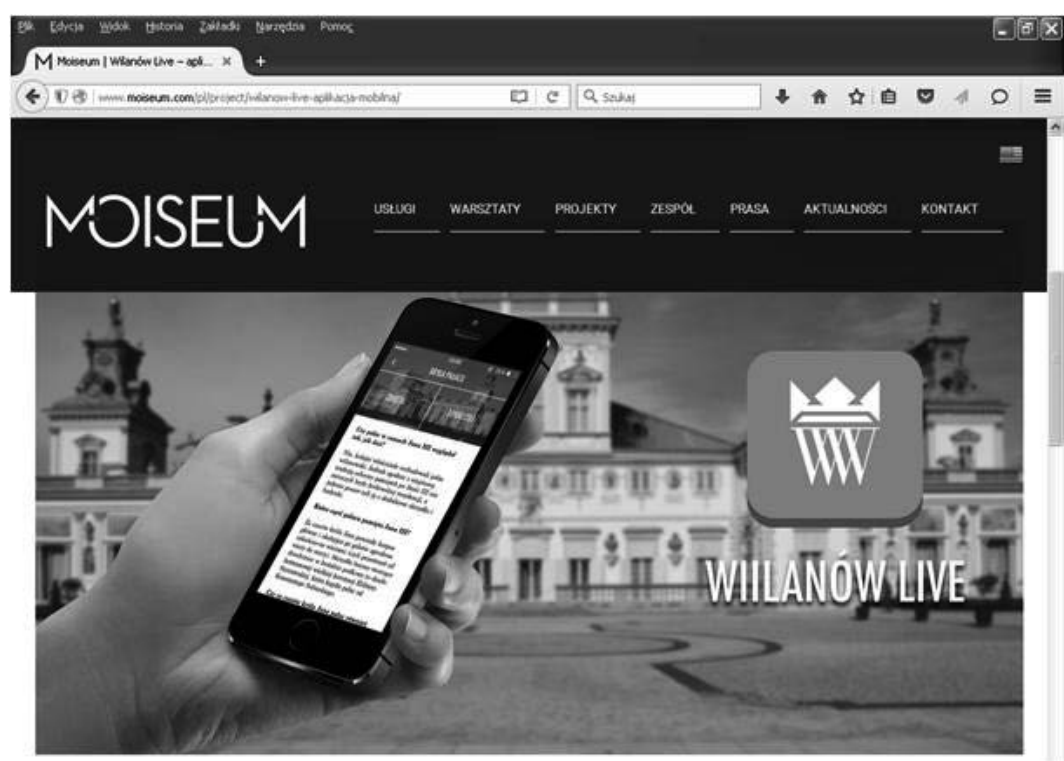

Figure 5.17 "Wilanów Live" mobile application of the Museum of King Jan III's Palace at Wilanów. Source http://www.moiseum.com/pl/project/wilanow-live-aplikacja-mobilna/ (accessed 21 Aug 2016)

The museum has been implementing its strategy of creating mobile projects for many years. The palace can be visited using the application with an audio guide, while signs with QR codes are scattered throughout the park. The museum needed an application that would somehow link existing projects together which visitors would download immediately after arriving at Wilanów or even during the visit. The Wilanów Live application shows all the information that museum visitors would want to have before and during the visit. This is standard information about the opening hours and ticket prices, news from the life of the museum, information about the events, exhibitions and activities taking place in Wilanów, a brief guide to the ten buildings located in the park and the palace, a map of the park, as well 
as links to the two existing guide applications. The iOS application uses a visual novelty parallax scrolling visible on the main screen and in the guide. The application uses push notifications, so the museum can directly communicate with users. In addition, the project included App Store Optimization and advertising visuals.

\section{3 "My Warsaw" mobile application}

In connection with the celebration of the Janusz Korczak Year, the Museum of the History of Polish Jews with the History Meeting House decided to implement a project with a mobile application "My Warsaw" (iOS/Android) which is a combination of a guide to the life of Janusz Korczak and a city game (Figure 5.18).

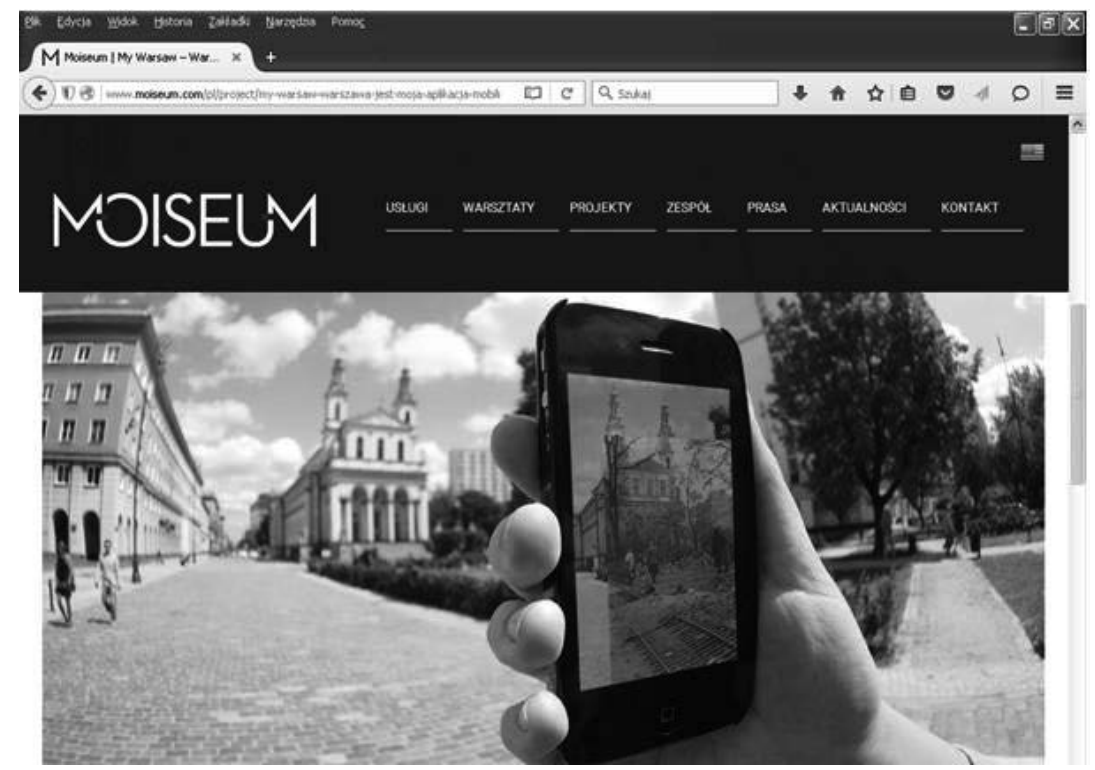

Figure 5.18 "My Warsaw" - a mobile application, Museum of the History of Polish Jews and the History Meeting House. Source http://www.moiseum.com/pl/project/my-warsaw-warszawa-jest-moja-aplikacjamobilna/ (accessed 30 Jan 2016)

The application includes two thematic routes related to the life of the Old Doctor, which together have 49 points located on the map of Warsaw. Each point contains several archival photos, information about Janusz Korczak, and a quote from his works, also available as an audio version. In addition, each of the points contains one photo which can 
be viewed in Augmented Reality, not previously used on such a scale in Poland. By superimposing a semi-translucent archival image, we can get as close as possible to seeing the capital during the 1930s and 1940s. The application is also a city game - some of the points are locked. To see them, you must complete the tasks presented to you at unlocked points - you have to answer a question, choose the correct answer, or take a picture in a designated place. The application has been integrated with social media (Facebook, Twitter, Foursquare).

\subsection{Mobile application of the Lódź City Museum}

In December 2014, a project of two applications intended for interactive kiosks based on Android tablets was implemented for the Łódź City Museum. It was a big challenge because the tablets were the largest available on the market at that time in terms of the screen size of 21.5 inches. At the same time they were not very efficient devices. The applications were to deepen the visitors' knowledge of the famous Łódź composer Aleksander Tansman. One of them is a calendar of the musician's life, presented in the form of an interactive lifeline, with photos, a voice-over, and music. The application is bilingual. Further functionalities of this application include a gallery of scores, where you can take a look at scans of the original scores of Tansman's works and listen to recordings, as well as three unique scores. Looking at the score while playing back a recording, the user can keep track of which notes are being played at a given moment. The effect is a bit like playing karaoke and thanks to this, the user can consciously keep up with a complicated musical piece. 




Figure 5.19 Mobile applications from the Łódź City Museum.

Source http://www.moiseum.com/pl/project/my-warsaw-warszawa-jest-moja-aplikacja-mobilna/ (accessed 30 Jan 2016)

The second application is a music mixer (Figure 5.19), by which the users can come to understand the basic laws of physics that govern music. By modifying Tansman's selected works, you can change the tempo, intensity, add effects, and record your own voice.

\section{5 "Archimapa" and "Via Ducalis" mobile planners}

Mobile travel planners and guides are becoming increasingly popular (e.g. Archimapa - a mobile guide to Warsaw architecture, or Via Ducalis - the "princely route" which takes the tourist on a trail of the monuments of Cieszyn Silesia, associated with the princely Piast and Habsburg dynasties), offering among other things a rich database of information about places, an events calendar and an access map.

The Archimapa application is a mobile guide to the architecture of Warsaw, which is available in Polish and English. It is based on an acclaimed series of maps published by the Warsaw Uprising Museum in printed form. Archimapa shows the seven most interesting often previously undescribed issues related to Warsaw's 20th century architecture, each of which is a thematic proposal for city exploration. With this application anyone can plan 
their route (sightseeing, trips, walks), finding not only information about architecture, architects, and the history of over four hundred buildings, but also details about their availability.



Figure 5.20 "Archimapa" mobile application - screenshot.

Source http://www.moiseum.com/pl/project/aplikacje-mobilne-archimapa/ (accessed 21 Aug 2016)

Geolocation allows the users to easily find undiscovered places and move with greater freedom in the urban space. By using offline maps the application can be used without access to the Internet. Numerous illustrations facilitate the identification of the buildings and places marked on the map. The texts in the Archimapa have been written by eminent scholars and critics of Warsaw architecture, as well as writers and popularizers of knowledge about the city. Archimapa features the following texts: "Warszawa niezaistniała 1944", “Architektura Warszawy 20-lecia międzywojennego 1918-1939”, "Warszawski socrealizm 1949-1956" - Grzegorz Piątek, Jarosław Trybuś, "Dziedzictwo architektury Warszawy 1945-1989” - Maria Sołtys, Marek Kuciński, “Żydowskie dziedzictwo. Warszawa, Falenica, Otwock" - Beata Chomątowska, "Ancymapa. Warszawa dla dzieci" - Sylwia Chutnik, "Mozaiki warszawskie" - Paweł Giergoń.

"Droga Książęca - Via Ducalis", an application for mobile devices which is a multimedia guide to the "princely route", takes the tourist on a trail of monuments associated with the princely Piast and Habsburg dynasties. The application can be downloaded for free from Google Play, available for the Android system. It is to be available soon for other systems. 
The scope of the application includes monuments located in the historical part of Cieszyn Silesia, i.e. not only in Poland but also in the Czech Republic. The beautiful monuments are located in such places as Cieszyn, Czechowice-Dziedzice, Frydek-Mistek, Skoczów, or Bielsko-Biała (Figure 5.21).



Figure 5.21 "Droga Książęca - Via Ducalis" application for mobile devices - screenshot Source http://cieszyn.naszemiasto.pl/artykul/kolejna-aplikacja-mobilna-powstala-w-naszym powiecie,3364424,art,t,id,tm.html (accessed 11 Aug 2016)

The application is very transparent. Among the tabs such functions as a map can be found, on which all the monuments on the trail are marked. To make it easier to reach them, you can use the navigation available in the application that guides tourists to the various monuments. Each of the buildings included in the application has a short description including the most interesting information about it. In addition, the application features four routes that can be covered on foot, by bike, or car. The last tab "events" contains information about the most interesting cultural events in the Cieszyn Silesia region. The application also has a QR code scanner, the option to share on social networks, and a directions module. Continuous access to the Internet is not required - it is only needed to perform updates or get driving directions. The mobile guide also has a Czech language version. 


\section{References}

Archimapa mobile application screenshot, http://www.moiseum.com/pl/project/aplikacje-mobilne-archimapa/ accessed 21 Aug 2016

A screenshot of the online shop of the Metropolitan Opera, http://www.metopera.org/ accessed 20 Aug 2016

Baird C.H., Parasnis G. (2011), 'From social media to Social CRM. What customers want. Part 1', IBM Institute for Business Value. http://www- 935.ibm.com/services/us/gbs/thoughtleadership/ibv-social-crmwhitepaper.html accessed 2 Aug 2014

Barrera J.F., Mira A., Torroba R. (2013), 'Optical encryption and QR codes: secure and noise-free information retrieval', Optics Express, Vol. 2 (5):5373-5378

Carr E. (2005), 'Web Sites for Culture. Essential Principles for Great Arts Web Sites', A division of Patron Technology, New York

Carr E. (2004), 'Sign-Up for Culture. The Arts Marketer's Guide to Building an Effective E-mail List', A division of Patron Technology, New York

DailyArt application screenshot, http://www.moiseum.com/pl/project/dailyart-aplikacja-mobilna/ accessed 30 Jan 2016

Droga Książęca - Via Ducalis - application for mobile devices screenshot, http://cieszyn.naszemiasto.pl/artykul/kolejna-aplikacja-mobilna-powstala-w-naszym powiecie,3364424,art,t,id,tm.html accessed 11 Aug 2016

Hologram of the statue of Johann Strauss promoting the city of Vienna in Warsaw, http://www.digitalemotions.pl/projekty/ accessed 1 Jan 2016

Holographic concert of Hatsume-Miku on YouTube, http://www.polskieradio.pl/23/267/Artykul/275769,Gwiazdy-pop-przyszlosci-to-hologramy accessed 1 Feb 2016

Jones J. (2016), 'Social Media, Marketing, and the Opera Singer, A Research Paper Presented in Partial Fulfillment of the Requirements for the Degree Doctor of Musical Arts', doi:10.13140/RG.2.1.3162.4560

Gargiulo M., Benassi M. (2000), 'Trapped in Your Own Net? Network Cohesion, Structural Holes, and the Adaptation of Social Capital', Organization Science, Vol. 11(2)

Kajfosz K. (2014), 'Wirtualni rozmówcy jako przykład wykorzystania systemów opartych na wiedzy w instytucjach kultury, sztuki i turystyki kulturowej', in Gołuchowski J., Spyra Z. (eds) Zarzadzanie w kulturze, sztuce i turystyce kulturowej, CeDeWu, Warszawa, pp 339-344

Kaplan A.M., Haenlein M. (2010), 'Users of the Word, unite! The challenges and opportunities of Social Media', Business Horizons, Vol. 53(1)

Karaman S., Bagdano A.D., D’Amico G., Landucci L., Ferracani A., Pezzatini D., Del Bimbo A. (2013), Passive Profiling and Natural Interaction Metaphors for Personalized Multimedia Museum Experiences, MM4CH'13 - New Trends in Image Analysis and Processing — ICIAP 2013, pp 247-256 
Kidzone - an educational project of the New York Philharmonic, http://www.nyphilkids.org/composition/main.phtml accessed 3 Feb 2016

Kopera S. (2009), 'Social software in information environment of tourist enterprise', in Kubiak B.F., Korowicki A. (eds) Information Management, Gdańsk University Press, Gdańsk

Kopera S., Najda-Janoszka M., Wszendybył-Skulska E. (2014), 'Kanał YouTube jako przykład wykorzystania mediów społecznościowych w procesie transferu wiedzy do biznesu turystycznego', Folia Turistica, Vol. 32 , pp. $55-72$

Le H., Jones B., Williams T., Dolnicar S. (2016), 'Communicating to culture audiences', Marketing Intelligence \& Planning, Vol. 34(4), pp. 462-485, doi:10.1108/MIP-05-2015-0102

Lehman K., Roach G. (2011), 'The strategic role of electronic marketing in the Australian museum sector', Museum Management and Curatorship, Vol. 26(3), pp. 291-306, doi:10.1080/09647775.2011.585806

Lupa I. (2014), ‘Marketing mediów społecznościowych w instytucjach kultury - szanse i bariery', in Wróblewski Ł. (ed) Zarzadzanie w instytucjach kultury, CeDeWu, Warszawa

Mobile applications from the Łódź City Museum, http://www.moiseum.com/pl/project/my-warsaw-warszawajest-moja-aplikacja-mobilna/ accessed 30 Jan 2016

Moni i Uszko - a multimedia series for kids from the National Opera in Warsaw, http://katila.com.pl/TeatrWielki/GraMoniUszko-wTeatrze/ accessed 3 Feb 2016

My Warsaw - a mobile application, Museum of the History of Polish Jews and the History Meeting House, http://www.moiseum.com/pl/project/my-warsaw-warszawa-jest-moja-aplikacja-mobilna/ accessed 30 Jan 2016

Nemeth C.J. (1997), 'Managing Innovation: When Less is More', California Management Review, Vol. 40(1), pp. 55-59

Neuhofer B., Buhalis D., Ladkin A. (2014), ‘A Typology of technology enhanced tourism experiences', International Journal of Tourism Research, Vol. 16(4), pp. 340-350

Nogieć J. (2005), Kształtowanie wizerunku szkoły wyższej w Internecie. Zeszyty Naukowe Uniwersytetu Szczecińskiego. Marketing przyszłości 414, Szczecin

Online shop of The Metropolitan Museum of Art in New York, http://store.metmuseum.org/bracelets/tibetandragon-cuff/invt/09064411 accessed 20 Aug 2016

Rialti R., Zollo L., Ciappei C., Laudano M. (2016), 'Digital cultural heritage marketing: The role of digital technologies in cultural heritage valorization', Global Marketing Conference at Hong Kong Proceedings, pp. 1062-1063, doi:10.15444/GMC2016.07.09.01

Scott D.M. (2011), How to Use Social Media, Online Video, Mobile Applications, Blogs, News Releases \& Viral Marketing to Reach Buyers Directly, John Wiley \& Sons, Hoboken

Sobocińska M. (2015) Uwarunkowania i perspektywy rozwoju orientacji rynkowej w podmiotach sfery kultury. Wydawnictwo Uniwersytetu Ekonomicznego we Wrocławiu, Wrocław 
Sparacino F. (2004), 'Museum intelligence: using interactive technologies for effective communication and storytelling in the "Puccini Set Designer" exhibit', Archives \& Museum Informatics Vol. 2, pp. 1-40

Sznajder A. (2015), Marketing sportu, PWE, Warszawa 2015

Virtual advisor of the Cluster Culture and Industrial Tourism - screenshot, http://klasterkultury.pl/index.php?option=com_content\&view=article\&id=209:wirtualny-doradcamobilnie \&catid=8\&Itemid=110\# accessed 30 Jan 2016

Virtual piano of Chopin, http://ogx.mchtr.pw.edu.pl/images/projects_chopin_3.jpg accessed 3 Feb 2016

Virtual press office of the Louvre Museum in Paris, http://presse.louvre.fr/en/ accessed 20 Aug 2016

Virtual tour of St. Mary's Church in Krakow, http://www.pajorama.eu/wirtualnymariacki/mariacki.html\#/Prezbiterium/accessed 21 Aug 2016

Wallace E., Buil I., Chernatony L., Hogan M.J. (2014) 'Who "Likes” You...and Why? A typology of Facebook Fans', Journal of Advertising Research, Vol. 54, pp. 92-109

Walmsley B. (2016), 'From arts marketing to audience enrichment: How digital engagement can deepen and democratize artistic exchange with audiences', Poetics, doi:10.1016/j.poetic.2016.07.001

Walotek-Ściańska K. (2015), Teatry publiczne w województwie ślaskim a social media, Wydawnictwo Naukowe Śląsk, Katowice

Weissblog - blog of the Baltic Opera, http://www.operabaltycka.pl/blog/ accessed 8 Feb 2016

Wierenko T. (2005), Internet jako nowoczesne medium. Zeszyty Naukowe Uniwersytetu Szczecińskiego. Marketing przyszłości 414, Szczecin

Wilanów Live - mobile application of the Museum of King Jan III's Palace at Wilanów, http://www.moiseum.com/pl/project/wilanow-live-aplikacja-mobilna/ accessed 21 Aug 2016

Woodcock N., Green A., Starkey M. (2011), 'Social CRM as a business strategy', Journal of Database Marketing \& Customer Strategy Management, Vol. 18(1), p. 64, http://www.palgrave-journals.com/doifinder/10.1057/dbm.20117 accessed 12 Feb 2013

Wróblewski Ł. (2016), Marketing strategiczny w sektorze kultury Euroregionu Śląsk Cieszyński. Wydawnictwo CeDeWu, Warszawa

YouTube channel of the Royal Opera House in London, https://www.youtube.com/user/RoyalOperaHouse accessed 20 Aug 2016 



\section{Summary}

The beginning of the twenty-first century has brought significant changes in the functioning of cultural institutions, but above all in the mentality of people - artists, creators, and especially the heads of arts organizations. They must confront new market realities, such as globalization, increasing competition within the sector, the wider sphere of entertainment, and the increasingly accelerated deployment of new technologies. The customers are also changing, ceasing to be merely the recipients of art and becoming the creators of the market. Both these circumstances, as well as the high competition in other spheres, the wider sphere of entertainment in general, and leisure activities has meant that a large number of cultural institutions have changed their product orientation and began to operate in accordance with market orientation. This change, however, still raises a lot of controversy and is met with opposition from many representatives of the so-called "art world". The adoption of a marketoriented approach is for many heads (especially artistic directors) of cultural institutions still synonymous with the creation and dissemination of culture under the dictation of its recipients. Of course, the possibility of applying many model solutions known from source literature, i.e. strategies that are perfect for large corporations, are limited in the activities of cultural institutions. Some of them, however, can be modified and successfully used in cultural institutions. It should be remembered that the product offered by cultural institutions is very specific, so we must make sure that a balance is maintained between opinions about culture, with its inherent value and the need to protect it at all costs, and also the opinion that - like any other form of human activity - it should be profitable. Appropriate strategic or marketing management in the activities of cultural institutions can significantly contribute to the maintenance of this balance. 



\section{Tables and Figures}

\section{Tables}

1.1 Essen Declaration - 10 axioms for cultural industries...................... 24

1.2 Categorization of culture, cultural industries and creative industries............ 27

1.3 Institutional typology of the culture sector - in the broad definition............. 31

2.1 Reasons for adapting and implementing marketing concepts in the cultural sector.

3.1 Difficulties associated with the formulation of the mission in entities in the cultural sector.................................... 67

3.2 Missions of Polish opera houses and concert halls......................... 68

3.3 Strategic objectives of entities in the cultural sector........................ 72

3.4 Strategic objectives of Polish opera houses and concert halls................ 73

3.5 Difficulties in defining strategic objectives in entities in the cultural sector..... 82

3.6 Types of customer segmentation in the cultural sector.................... 84

3.7 Internal and external factors determining the choice of a particular course of action in the entities in the cultural sector............ 92

3.8 Factors influencing the choice of the course of action...................... 92

3.9 Scope of marketing activities in the cultural sector entities................. 96

4.1 Definitions of the measures of the strength of a relationship between cultural institutions and the consumers of the offer, donors and employees.......

4.2 Relationship of the core of the concert hall's product with the basic value for the listener.................................. 118

4.3 Guild Member benefits by tier.................................... 121

4.4 Corporate patron benefits by level................................... 127

4.5 Additional benefits offered to selected consumers of the cultural offer of the National Philharmonic in Warsaw................................. 129

4.6 Key benefits sought by artists..................................... 136 
5.1 Objectives for the use of social media in various types of cultural institutions.

5.2 Social media in the activities of Warsaw's theaters - as of 04.02.2016

5.3 Facebook and Twitter in the activities of the leading opera houses in the world - as of 04.02.2016.

5.4 YouTube in the activities of leading opera houses - as of 04.02.2016.

Figures

1.1 Division of culture................................................. 21

1.2 Relationship between culture and cultural industries........................ 25

1.3 Model of cultural industries by Throsby............................... 26

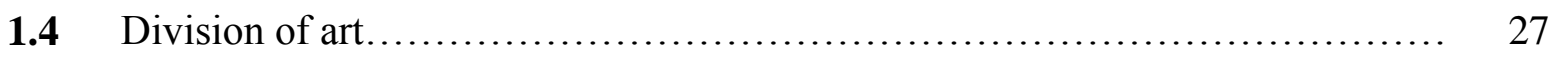

1.5 Typology of creative industries according to DCMS ....................... 30

1.6 Value chain in the music industry.................................. 33

1.7 Relationship between culture, cultural industries and creative industries.......... 34

1.8 Division of cultural institutions on the grounds of their focus on marketing.... 36

1.9 Proportion of people employed in the cultural sector in relation



2.1 Achievement of artistic and economic objectives in the cultural sector potential variants

2.2 Market conditions for the development of the concept of marketing in the cultural sector.

2.3 Relationship between the method of focusing on the product/market and the type of entity in the cultural sector.

2.4 Marketing model in cultural entities focused on the product. 60 
2.5 Marketing model in cultural entities focused on the market

3.1 Strategic objectives of cultural institutions, companies in industries

- continuum

3.2 Factors influencing the choice of marketing strategy

in cultural institutions and cultural industries...

3.3 Types of segmentation

3.4 Levels of the public in the cultural sector.

3.5 Methods of the activities of cultural entities and market segmentation....

3.6 Basic instruments of the marketing mix of entities in the cultural sector

3.7 Preferred marketing mix instruments in the opinion of surveyed managers of culture, as well as customers and potential customers of cultural institutions in Euroregion Śląsk Cieszyński

3.8 The vicious circle in the process of the implementation of the marketing strategy in the cultural sector.

4.1 The process of cultural institutions building long-term relationships with the consumers of artistic offerings, donors and employees

4.2 Pyramid of opera and concert hall goers.

4.3 Types of donors of cultural institutions

5.1 Method of obtaining information by respondents about the cultural institutions' offer in Euroregion Śląsk Cieszyński

5.2 Online shop of the Metropolitan Museum of Art in New York

5.3 A screenshot of the online shop of The Metropolitan Opera.

5.4 Virtual press office of the Louvre Museum in Paris.

5.5 "Kidzone" - an educational project of the New York Philharmonic

5.6 "Moni i Uszko" - a multimedia series for kids from the National Opera in Warsaw.

5.7 New look at the role of a participant in culture in the process of value management.

5.8 Trends in the growth of the Internet 
5.9 YouTube channel of the Royal Opera House in London...................... 161

5.10 Weissblog - blog of the Baltic Opera................................... 163

5.11 Virtual advisor of the Cluster Culture and Industrial Tourism - screenshot..... 165

5.12 Holographic concert of Hatsume-Miku on YouTube......................... 166

5.13 Hologram of the statue of Johann Strauss promoting the city of Vienna in Warsaw.......................................................... 167

5.14 Virtual tour of St. Mary's Church in Krakow............................... 170

5.15 Virtual piano of Chopin............................................ 171

5.16 DailyArt application - screenshot................................... 174

5.17 "Wilanów Live" mobile application of the Museum of King Jan III's Palace at Wilanów

5.18 "My Warsaw" - a mobile application, Museum of the History of Polish Jews and the History Meeting House......................................... 176

5.19 Mobile applications from the Łódź City Museum......................... 178

5.20 "Archimapa" mobile application - screenshot........................... 179

5.21 "Droga Książęca - Via Ducalis" application for mobile devices - screenshot... 180 


\section{Biographies}

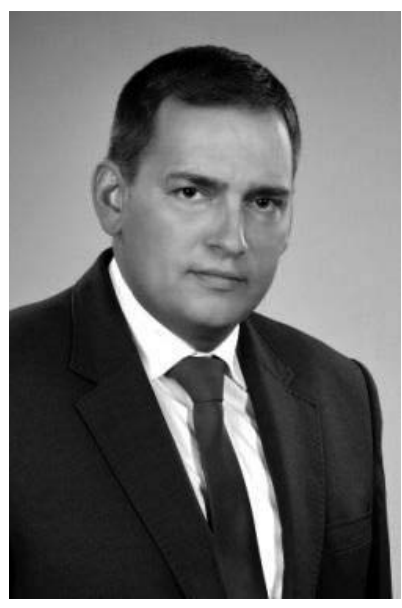

Lukasz Wróblewski, Ph.D. specializes in theoretical and practical issues relating to marketing and strategic management. He has authored over 50 scientific publications, mostly concerning issues of management and marketing in cultural organizations. He has been a speaker and participant in more than one hundred scientific conferences, numerous training courses and workshops. He has also organized several symposiums and conferences on this management and marketing specialty in Poland and the Czech Republic. Currently he is lecturer of marketing and marketing management at the University of Dąbrowa Górnicza (Poland).

\section{Sample Publications}

- Marketing strategiczny w sektorze kultury Euroregionu Śląsk Cieszyński (Strategic Marketing in the Cultural Sector of the Euroregion Cieszyn Silesia), Wydawnictwo CeDeWu, Warsaw 2016.

- Zarządzanie w instytucjach kultury (Management in Cultural Institutions), scientific editor, Wydawnictwo CeDeWu, Warsaw 2014.

- Strategie marketingowe w instytucjach kultury (Marketing Strategies in Cultural Institutions), Polskie Wydawnictwo Ekonomiczne, Warsaw 2012.



Bonita M. Kolb, Ph.D. is Emeritus Professor of Business Administration at Lycoming College, Williamsport, USA. She has also taught business classes to graduate students in cultural management, art, and music programs at the Pratt Institute in New York, the Sibelius Academy in Helsinki, and the Estonian Academy of Theater and Music in Tallinn. She has conducted marketing research with cultural institutions in both the USA and Europe such as the Brooklyn Museum of Art, Opera Ebony, the London Philharmonic Orchestra, and the BBC Proms. Currently she works as consultant and keynote speaker.

\section{Sample Publications}

- Tourism Marketing for Cities and Towns: Using Social Media to Co-Create Authentic Tourism Experiences, 2nd Ed., Routledge, London, New York 2017. 
- Social Media and the Desire for Authentic Travel Experiences, Routledge, London, New York 2016.

- Marketing Strategy for the Creative and Cultural Industries, Routledge, London, New York 2016.

- Entrepreneurship in the Creative and Cultural Industries, London, New York Routledge 2015.

- Marketing for Cultural Organizations: New Strategies for Attracting Audiences. 3rd Ed., Routledge, London, New York 2013.

- Using Social Media to Enhance the Attendance Experience, Routledge, London, New York 2013.

- Marketing Research: A Practical Approach, SAGE, Los Angeles, London 2008.

- Marketing Research for Non-profit, Community and Creative Organizations, Elsevier, Burlington, Oxford 2008.

- Marketing Cultural Organisations: New Strategies for Attracting Audiences to Classical Music, Dance, Museums, Theatre and Opera. 2nd Ed., Thomson, London 2005.

- Marketing Cultural Organisations: New Strategies for Attracting Audiences to Classical Music, Dance, Museums, Theatre and Opera, Oak Tree Press, Cork 2000. 



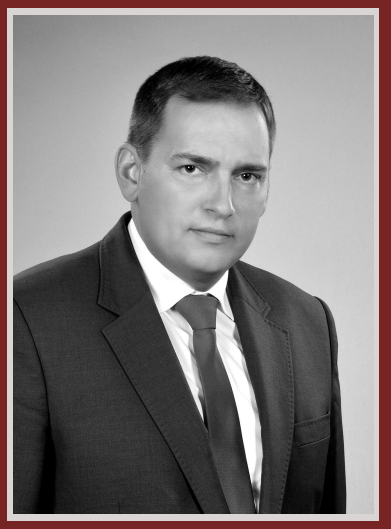

Łukasz Wróblewski, Ph.D. specializes in theoretical and practical issues relating to marketing and strategic management. He has authored over 50 scientific publications, mostly concerning issues of management and marketing in cultural organizations. He has been a speaker and participant in more than one hundred scientific conferences, numerous training courses and workshops. He has also organized several symposiums and conferences on this management and marketing specialty in Poland and the Czech Republic. Currently he is lecturer of marketing and marketing management at the University of Dąbrowa Górnicza (Poland).

"Dr Łukasz Wróblewski's book Culture Management: Strategy and Marketing Aspects clearly recognises that the pressures on the cultural sector in the 21 st Century are greater than ever before. Based on robust academic research within a practical industry context, this book addresses all the key issues related to marketing strategy and planning for the cultural industries. It will be an invaluable tool for managers, policy-makers and all those working in the creative and cultural world, and will help them to develop sound strategies for the future."

Dr Kim Lehman • Tasmanian School of Business and Economics, University of Tasmania

"Dr Wróblewski's book explains clearly what has changed to make the use of business models necessary, even in organizations which might have resisted in the past. Globalization has resulted in a population which understands and appreciates art and culture created in other countries. While it might be agreed that this is beneficial for society, it means that cultural arbitrators within a country no longer have the authority to dictate what is accepted as culture. Managers now understand that to gain the support of the public they must explain the benefits of consuming their cultural product."

Dr Bonita M. Kolb • Professor Emeritus of Lycoming College in Pennsylvania

"A thoughtful and penetrating analysis of culture management addressing marketing strategies and cultural institutions. An important 'must read' book for those involved in this exciting sector."

Prof Adrian Payne • University of UNSW Business School, University of New South Wales 